\title{
Manufacturing Revolutions: Industrial Policy and Industrialization in South Korea*
}

\author{
Nathan Lane ${ }^{\dagger}$ \\ Current Version: November 2022 [First Draft: October 2016]
}

\begin{abstract}
I study the impact of industrial policy on industrial development by considering a canonical intervention. Following a political crisis, South Korea dramatically altered its development strategy with a sector-specific industrial policy: the heavy and chemical industry (HCI) drive, 1973-1979. Based on newly assembled data, I use the introduction and withdrawal of industrial policies to study the impacts of industrial policy during and after the intervention period. (1) I reveal that HCI promoted the expansion and dynamic comparative advantage of directly targeted industries. (2) Using variation in exposure to policies through the input-output network, I demonstrate that $\mathrm{HCI}$ indirectly benefited downstream users of targeted intermediates. (3) I determine that the direct and indirect benefits of HCI persisted even after the end of HCI, following the 1979 assassination of the president. These benefits include the eventual development of directly targeted exporters and their downstream counterparts. Together, my findings suggest that this temporary drive shifted Korean manufacturing into more advanced markets, creating durable industrial change. These findings clarify lessons drawn from South Korea and the East Asian growth miracle. JEL: L5 O14 O25 N6. Keywords: industrial policy, East Asian miracle, economic history, industrial development, Heavy-Chemical Industry Drive, Heavy and Chemical Industry Drive.
\end{abstract}

\section{Introduction}

Miracles by nature are mysterious. The forces behind the East Asian growth miracle are no exception. Industrial policy (IP) has defined Asia's postwar transformation (Rodrik 1995). Early development economists saw these policies as essential for industrial development (Rosenstein-Rodan 1943; Nurkse 1953; Hirschman 1958),

${ }^{*}$ I benefited from comments from anonymous referees, Daron Acemoglu, Robert Allen, Sam Bazzi, Sascha O. Becker, Nils Bohr, Timo Boppart, Eric Chaney, David Cole, Arin Dube, Samantha Eyler-Driscoll, Alice Evans, Reka Juhasz, Mounir Karadja, Max Kasy, Oliver Kim, Changkeun Lee, Weijia Li, Ernest Liu, Andreas Madestam, Javier Mejia, Matti Mitrunen, Arieda Muco, Aldo Musacchio, Suresh Naidu, Nathan Nunn, Veronica Perez, Dwight Perkins, Pseudorasmus, Erik Prawitz, Pablo Querubin, Dani Rodrik, Martin Rotemberg, Todd Tucker, Eric Verhoogen, Robert Wade, and Lisa Xu. I would like to thank audiences at American University, Australia National University Economics, Australia National University (Crawford School), Azim Premji University, Central European University, Columbia University, CSAE Oxford, College de France, Geneva Graduate Institute Blended Finance Conference, EBRD, European Econometric Society Summer and Winter Meetings, Berkeley, Harvard, IMT Lucca, Institute of New Structural Economics-Peking University, INSEAD, Kellogg School of Management, King's College London, Korea Development Institute, LSE ID, MIT, NBER SI, NEUDC, Nottingham University, NYU-Abu Dhabi, University of Oxford, Oxford ESH, OzClio, Queen Mary, Seoul National University, Sussex University, UMASS-Amherst, University of Melbourne, UNSW, University of Technology Sydney, and University of Wollongong for valuable comments. I would especially like to thank my committee: Melissa Dell, Torsten Persson, James Robinson, and David Stromberg. This study was made possible with the excellent assistance of Ida Brzezinska, Seung Yeon Han, BoSuk Hong, Chan Kim, Veronic Perez, Cheong Yeon Won, and Hye Jin Won. I would also like to thank the staff of the Bank of Korea and the Korea Development Institute.

${ }^{\dagger}$ University of Oxford and SoDa Labs (Monash). See nathanlane.info or contact me at nathaniel.lane@economics.ox.ac.uk 
and scholars have argued they were instrumental to East Asia's ascent (Wade 1990; Amsden 1992). Other economists have been skeptical about their use (R. E. Baldwin 1969; Krueger 1990), and argued their role in Asia may have been counterproductive (Pack 2000). South Korea exemplifies both Asia's rapid transformation and the region's controversial use of industrial policies. The economy entered 1960s as a politically unstable industrial laggard. By the 1980s, it had undergone a manufacturing transformation that had taken Western economies over a century to achieve (Nelson and Pack 1999). What role did industrial policy play in this transition? As industrial policy returns to prominence, evidence of its efficacy is scant, especially for its role in the East Asian episode (Lane 2020).

I study the impact of industrial policy on South Korea's transformation. I focus on its flagship heavy and chemical industry (HCI) drive, 1973 to 1979, and study its role in shifting Korea from a light export economy to an industrial powerhouse. The drive reflected the investment-focused interventionism of early development economics, but also the new export-oriented policy experiments pursued across East Asia. Inspired directly by Japan's earlier success, and bearing similarities to contemporaries, like Taiwan (Cheng 1990, 2001), South Korea's program influenced industrial strategies across the globe (D. H. D. Kim et al. 2013). The varied record of its imitators—and lack of empirical evaluation—has fueled HCI's notoriety (Moreira 1994; Lall 1995, 1996).

I evaluate the impact of IP on short-term and long-term industrial development using variation introduced by the South Korea's HCI program. External politics precipitated the introduction of the heavy industry drive in 1973 and its termination in 1979. The Nixonian shock, President Nixon's promise to withdraw U.S. forces from the Asia-Pacific arena, rattled Western allies. The U.S. military withdrawal catalyzed South Korea to incubate its own military-industrial complex. South Korea's industrial strategy shifted from a horizontal, export-oriented strategy to a new strategy, concentrated on a set of strategically important heavy industries (Krueger 1979; Westphal 1990; Stern et al. 1995; B. Kim 2011). However, the heavy industry drive ended up being largely temporary. The assassination of the South Korean president, Park Chung-hee, in 1979 effectively ended the regime's program. This study is the first to use this temporal and sectoral variation to estimate the impacts of the policy. Using historical evidence, I argue (Section 2) that the HCI context provides useful features to econometrically study the impact of purposeful IP.

I estimate the impact of South Korean industrial policy by comparing changes in outcomes between targeted versus nontargeted manufacturing industries, each year before and after HCI implementation. This dynamic difference-in-differences (DD) strategy captures the impacts of heavy industry policies, which were centered on directed credit, and, to a lesser extent, overt protection. Industry pre-trends inform Korea's counterfactual sectoral structure. Without these interventions, industries would have evolved according to their current pattern of comparative advantage. I refer to Korea's pattern of comparative advantage prior to the intervention as static comparative advantage. Differences after 1973 reveal the potential efficacy of IP in promoting dynamic comparative advantage. ${ }^{1}$ This occurs where policy is associated with the evolution of industrial development and new patterns of specialization.

Empirically, I consider the average impact of policy on treated industries (or ATT). I estimate these impacts using traditional two-way fixed effect (TWFE) estimators. I then build on this baseline method in two ways. First, I use a doubly robust estimator (Callaway and Sant'Anna 2020; Sant'Anna and Zhao 2020), which combines outcome regression and propensity score models. Next, I employ a cross-country triple differences (DDD) estimation strategy, comparing Korean manufacturing sectors to global placebo manufacturing sectors.

For this study I construct new data on industrial outcomes spanning Korea's miracle period (1967-1986). I harmonize material from primary source publications, digitized industrial surveys, and historical

${ }^{1 \prime}$ "Dynamic" refers to the emergence of new comparative advantage in industries through time. Static comparative advantage refers to the evolution of industry according to its current pattern of comparative advantage. This definition builds from Redding (1999), who defines dynamic comparative advantage, more generally, as a time-varying version of classic static comparative advantage. 
machine-readable statistics into consistent panel data. I then combine this industry-level data with digitized input-output (IO) accounts. The result is panel data covering a key episode of industrialization.

I highlight three empirical results. First, I find significant positive impacts of IP across a wide array of industrial development outcomes in targeted (treated) industries. Relative to pre-HCI levels, targeted heavy industries expanded their output by over 100 percent more than nontreated sectors, and labor productivity was more than 60 percent higher. I show that the relative expansion of HCI-targeted industries was not caused by a decline in nontreated industries. Because industrial development is multidimensional, I consider industrial development across outcomes. I find substantial effects of the program on employment growth, export performance, and output prices (10 percent lower for targeted after 1973). HCI not only appears to have durable effects on treated industries, but I also find evidence of persistent impacts on plant-level, total-factor productivity (TFP) in the post1979 period. I emphasize the role of investment policy and dynamic externalities. HCI sectors are correlated with higher learning-by-doing forces, as well as industry-wide, cross-plant learning spillovers.

Second, HCI promoted a shift in the long-term dynamic comparative advantage of the targeted export industry. Post-1979, industrial development outcomes, such as the share of economic activity, remained significantly higher than those of counterfactual industry. Moreover, HCI targeting is associated with the striking expansion of export activity: treated industries were 13 percent more likely to achieve comparative advantage in global markets after 1973, and the revealed comparative advantage (RCA) of HCI products increased 30 percent more than other manufacturing exports over the same period. Similarly, relative export productivity (Costinot, Donaldson, and Komunjer 2012) increased. Consistent with infant-industry theories of learning by doing, these benefits take time to gestate (Bardhan 1971; Corden 1997). Thus, shorter-term evaluations may not capture the full dynamic impacts of IP.

Third, HCI policies may have positively impacted downstream industry, including the longer-term development of downstream exporters. I find that downstream sectors with strong linkages to HCI-targeted industries expanded during the HCI period. During the drive, comparative advantage emerged among downstream exporters, and this advantage was fully realized post-1979. Conversely, the backward linkage effects of the drive were, at best, limited. Thus, HCI likely supported industrial development through supply-side effects passed through forward linkages. This aligns with recent research on optimal interventions in networks by Liu (2019), who, using IO data from this study, reveals that upstream HCI industries correspond to those that are theoretically suitable to target. Accounting for these linkages reduces the point estimates of the main effect but preserves the core pattern of industrial development for directly targeted industry. I do not find evidence that HCI policy reduced investment in nontreated industries.

This study makes four contributions. First, I build on emerging research that uses contemporary econometrics to study the impact of IP. The literature includes an earlier study by Nunn and Trefler (2010), which examined the relationship between the skill bias of trade policy and industrial development, and later case studies by Aghion et al. (2015) and Criscuolo et al. (2019). Complementary literature in empirical IO has begun to articulate a structural framework for analyzing sector-specific policy bundles, notably excellent work by Kalouptsidi (2018) and Barwick, Kalouptsidi, and Zahur (2019). Development work by Rotemberg (2017) and Martin, Nataraj, and Harrison (2017) has explored issues at the heart of IP in the context of Indian small and medium-sized enterprise (SME) policy. For earlier calibration-based evaluations, see R. Baldwin and Krugman (1988), Head (1994), and Irwin (2000).

Second, I contribute to the empirical study of IP through natural experiments and historical case studies. This paper is the first to use the HCI episode to estimate the impact of East Asian IP_— I join Juhasz (2018), who uses the Napoleonic blockade to test for infant-industry policy in France. Related studies by Inwood and Keay (2013) and Harris, Keay, and Lewis (2015) explore the effects of output market protection during Canada's early tariff experiments. Similar to this study, I find some evidence for the efficacy of infant-industry policy but in a contemporary setting with outward-oriented policies (export-focused) versus overt protectionism. 
My results align with case studies using temporary historical episodes to explore the process of dynamic comparative advantage (Hanlon 2020; Mitrunen 2019; Pons-Benaiges 2017). For temporary government procurement policy, technology, and managerial training, see the related studies by Jaworski and Smyth (2018) and Giorcelli (2019). I contribute to historical empirical research highlighting the potential of transitory policy to promote the long-run development of "sunrise" industries. I do so by examining a purposeful, targeted intervention in a modern context. In analyzing targeted policies, I speak to similar studies evaluating placebased policies; notably Criscuolo et al. (2019) and Becker, Egger, and Ehrlich (2010) use exogenous spatial variation to study the impact of IP support targeted at lagging geographical areas. I show the impact of policies aimed at sunrise industries in a (former) developing country setting rather than lagging (sunset) regions in a developed setting.

Third, I contribute to debates on the role of IP in development and in the East Asian miracle. On one hand, rich qualitative research, mostly outside economics, has emphasized the role of IP in newly industrializing economies (Johnson 1982; Chang 1993; Chibber 2002; and Kohli 2004). Notable work by Wade (1990) and Amsden (1992) argues that IP was vital to Taiwan's and South Korea's ascent. On the other hand, economists have largely been skeptical of industrial policies (Pack and Saggi 2006a; Noland and Pack 2003). For East Asia in particular, Krueger (1995) and Pack (2000) contend newly industrialized countries developed despite industrial strategy. I detail the rich critical literature on East Asian IP in Section 3. My study is a first attempt to address the debate surrounding the East Asian episode using modern econometric tools, and builds on important early correlation studies (Weinstein 1995; Beason and Weinstein 1996; Lawrence and Weinstein 1999). This econometric work parallels recent quantitative contributions by Liu (2019).

Lastly, I contribute to the discussion on the role of the state in development (Besley and Persson 2010, 2011; Acemoglu et al. 2015) — especially their role in promoting industrial change (Evans 1995; Kohli 2004). Using Vietnamese history as a case study, related work (Dell, Lane, and Querubin 2018) explores the effect of the Weberian state and its capacity to implement successful developmental policy in East versus Southeast Asia.

In sum, this study considers an influential IP episode using contemporary empirical tools. I use the heavy and chemical industry drive as an experiment to study the impacts of IP and attempt to derive a disciplined data-driven account of the episode. In doing so, I use numerous industrial development outcomes to generate a holistic empirical account of IP in a historical context, and I emphasize a data-driven approach to the study of East Asian development.

I organize my study as follows. In Section 2, I discuss the institutional setting of the heavy industry drive and detail the nature of the policies. In Section 3, I describe the general theoretical case for IP, and in Section 4, I describe my data. In Section 5, I present estimates of the direct impact of IP on targeted industries, and in Section 6, I turn to policies and policy mechanisms. Finally, I consider estimates of HCI's spillovers into external sectors through IO linkages in Section 7. I conclude in Section 8 with a discussion of my findings.

\section{Institutional Context}

I now turn to the institutional and historical context of the heavy and chemical industry drive. I focus on the impetus for the program, describe the selection of targeted sectors, and examine the policy before, during, and after the drive. I conclude by summarizing how the episode is useful for empirical analysis.

A) The Nixon Shock and Launch. Political crisis triggered South Korea's HCI drive, which was fundamentally security-driven (H.-A. Kim 2011; Moon and Jun 2011). Events in the late 1960s and early 1970s created a political impasse. The first was a turn in U.S. foreign policy in Asia and North Korea's militarization (E. M. Kim 1997; Moon and Lee 2009). In 1969, President Nixon announced the end of direct U.S. military support for its Asia-Pacific allies. This "Nixon Doctrine" effectively ended decades of large-scale military presence in the re- 
gion. U.S. disengagement created the risk of full U.S. troop withdrawal from the Korean Peninsula (Nixon 1969; S. J. Kim 1970; Kwak 2003). As with their South Vietnamese allies, South Korea believed it would need to defend itself against a more militarized, Communist-backed neighbor. See history section of the Online Appendix for details.

Panel B of Figure 1 plots the coverage of the U.S. troop withdrawal by the U.S. press, measured by the share of New York Times articles containing "South Korea" and "troop withdrawal." The first hump appears around 1970, at the confirmation of U.S. withdrawal from the Peninsula. This confirmation "profoundly" shocked the Park administration, which expected exemptions from Nixon's doctrine (Trager 1972; Rogers 1970; Nixon 1970; Kwak 2003, 34), and coverage grows during the 1971 troop pullout (24,000 troops and three air force battalions). The second jump in Panel B corresponds to the 1976 U.S. presidential campaign and the election of Jimmy Carter, who committed to reduce military involvement in South Korea (S. Han 1978; Taylor, Smith, and Mazarr 1990; N. Lee 2011; Joon-Kyung Kim, Shim, and Kim 1995) (this was complicated by Park's assassination in 1979).

The U.S. foreign policy shift came at a key juncture, coinciding with North Korea's military escalation (Ostermann and Person 2011). Panel A of Figure 1 plots the increasing antagonism of North Korea during this period, using the full-text archive of large Korean newspapers, Dong-A Ilbo and Kyunghyang Shinmun. The data shows the number of articles covering military antagonism, which is constructed by counting articles matching a dictionary of Korean-language keywords for military antagonism (e.g. 도발(provocation), 교전 (engagement), 남침(invasion of the South), 침투(infiltration), 폭파(explosion), 포격(shelling)). The Online Appendix describe the construction of this dictionary using seed terms and a word2vec-style Korean-language model. The pattern in Panel A tracks hand-coded data on military altercations by Choi and Lee (1989) (Online Appendix Figure 1).

Panel A in Figure 1 shows the attacks launched by North Korea following Nixon's announcement and tracks the tensions leading up to the announcement of HCI on January 12, 1973, after Park's suspension of democracy in late $1972 .{ }^{2}$ By the early 1970s, the North rivaled the South militarily, and pursued a total militaryindustrialization campaign since the 1960s (Hamm 1999). South Korea had not kept up. During the events in Figure 1, South Korea had no domestic arms industry, and experienced a string of high-profile security emergencies that tipped the regime toward crisis (Scobell and Sanford 2007; S.-Y. Kim 2001). Without U.S. troops, the South Korean weaponry was incapable of absorbing a North Korean blitz (Cushman 1979; Eberstadt 1999). These military-industrial exigencies drove the timing and scope of the HCI policy, which I turn to next.

B) Sectoral Choice and Debates About Viability. The 1973 HCI program broadly targeted six strategic sectors: steel, nonferrous metals, shipbuilding, machinery, electronics, and petrochemicals (Stern et al. 1995; Castley 1997). I define "treated" industries in this study as those listed in the enforcement decrees and national sectoral acts underlying HCI. These acts were part of the legal infrastructure upon which HCI was built. ${ }^{3}$ Appendix Table A1 lists the industries that fell under the six acts. I describe how I match industries in legislative appendices to industrial data in Section 4.

2See extensive treatments by Horikane (2005) and H.-A. Kim (2011). The HCI plan should not be conflated with Korea's aborted Third Five Year Economic Development Plan (1972-1976), which the HCI announcement effectively interrupted and consolidated (S.-C. Lee 1991).

${ }^{3}$ The core acts were the Petro-Chemical Industry Promotion Act; the Machine Industry Promotion Act; the Shipbuilding industry Promotion Act; the Electronics Industry Promotion Act; Iron and Steel Industry Promotion Act demarcate industries covered by the HCI Plan in 1973. The HCI Plan in 1973 used legislative acts that pre-dated the HCI drive, as this legislation was not fully implemented (Jong Kil Kim 1981, 82; Castley 1997) (see bellow). Presidential decrees would amend the enforcement and logistics of these acts through the HCI period. Industries defined in original sectoral acts remained stable. In very rare cases, additional products were added. 
Why were these sectors chosen, and what might deliberation around their selection tell us about their perceived potential? Two rationales dominated the choice of HCI sectors, as described by South Korean scholars and planners.

First, heavy industrial intermediates were seen as key for military-industrial modernization (S.-C. Lee 1991; Woo-Cumings 1998; H.-A. Kim 2011). In the early 1970s, South Korea lacked a military-industrial base comparable to that of the North. Military production was beyond the South's capabilities and early failures in arms manufacturing emphasized "inadequate" domestic materials (Horikane 2005, 375). Former official, Kim Chung-yum, reported it was "very apparent that the development of the heavy and chemical industries to the level of advanced countries was required to develop the defense industry" (C. Kim 2011, 409). Heavy intermediates were the means to an end. For planners, the steel and nonferrous metals sectors supplied crucial upstream materials for basic defense components, electronic components for electronic weaponry, and machinery for precision military production [ibid]. These rationales are echoed by former Park officials (Kwang Mo 2015).

Second, Korea intended to choose sectors that were not in conflict with comparative advantage. For direct downstream production, Korea lacked the technology and domestic market to manufacture at scale. Upstream intermediates were more technologically feasible, and their scale could be supported by fostering an export market (C. Kim 2011). For feasibility the regime studied the industrial strategies of contemporaries, including those in Western Europe (Perkins 2013) and, in particular, Japan.

For the heavy industry drive, Japan's experience was less a metaphor than a blueprint. The drive was drawn from the New Long-Range Economic Plan of Japan (1958-68), and Japan's experience gave South Korea a guide to sectors in which they had potential (Kong 2000; Moon and Jun 2011; B. Kim 2011). Alongside steel and metals, Woo (1991) notes that Korea's "strategy to promote shipbuilding was very simply a carbon copy of Japan's" [p. 137]. For completeness, Online Appendix Table 1 describes sectoral overlap between Korean HCI and Japan's 1950s sectoral policy (Okazaki 1998; Yoshioka and Kawasaki 2016) (also see Zeile (1993)). Kim Hyung-A, encapsulates the attention HCI planners paid to Japanese comparative advantage: "[Korea's] confidence was based largely on the experience of Japan, and calculated risk, rather than on unfounded speculation" (B. Kim 2011, 171-73). HCI planners followed the exports records of Japanese industry [ibid; K. Kim and Leipziger (1993), pp. 18-19].

Nevertheless, the potential of HCI was not obvious, ex-ante. International investors continuously raised doubts about the potential of Korean HCI and opposed funding earlier heavy industry projects (Amsden 1992; Redding 1999). The International Monetary Fund, U.S. Agency for International Development, and multiple European nations rejected loans for less ambitious projects (Rhyu and Lew 2011; Woo 1991). For example, in 1969, both the U.S. Export-Import Bank and the World Bank famously rejected loans for an early integrated steel mill, the Bank concluding that Korea "had no comparative advantage (emphasis my own) in the production of steel" (Rhyu and Lew 2011, 324; also C. Kim 2011). Lenders similarly rejected proto-HCI projects during the Nixon crisis; Japan rejected funding a four-factory precursor to the HCI drive and issued critical feasibility studies. European and the U.S. lenders also declined (Man 2019; H.-A. Kim 2011). By 1974, the International Bank of Reconstruction and Development's Economic Mission expressed "serious reservations about the practicability of many of the export goals set for individual heavy industries," arguing that Korea should pursue its current comparative advantage in light manufacturing [International Bank for Reconstruction and Development (1974); pg.8].

The doubts surrounding the potential of HCI explains why Park was unable to implement HCI earlier. Before HCI, under both U.S. and internal pressure from planners, Park had "no choice" but to abandon early heavy industry projects, lacking domestic capital with the U.S., South Korea have little "chance of getting the seed money to finance HCI projects" [Rhyu and Lew (2011); p.329]. Korea's own Economic Planning Board was 
reluctant to pursue the targeting Park envisioned under HCI (Choue 1988). The political economy of Park's post-1972 regime was likely necessary to finally realize HCI.

C) Policies Before, During, and After HCI. Announced in January 1973, HCI signaled a break with the horizontal "export-first" policy of the 1970s. This characterization of Korea's turn-from generalist to a decidedly sector-specific - is well documented (Frank, Charles R, Kim, and Westphal 1975; Krueger 1979; Westphal and Kim 1982; K. T. Lee 1992; Westphal 1990). I summarize the nature of pre-HCI policy, and then describe changes in the two main HCI policies: investment policy and trade policy.

Horizontal export promotion was a defining feature of pre-1972 policy, and the outcome of the First and Second Five Year Plans was South Korea's "export-first" strategy. Under the First and Second Five Year Plans, Korea implemented no less than 38 different incentives to promote exports (Lim 1981, 18). ${ }^{4}$ These incentives were aimed not at sectors but at export activity writ large. Under the pre-HCI export promotion regime, an exporting firm was essentially exempted from government restrictions (Lim 1981; T. Han 1998). Korean scholars argued that such exemptions restrictions essentially "allowed exporters to operate under a virtual free trade regime (emphasis mine)" (C.-H. Nam 1980, 9). This program did not have an overt sectoral bias. This is reflected by economists at the time. World Bank economist, Larry Westphal, described export incentives as "administered uniformly across all industries" [Westphal and Kim (1982); pp.217-218; Westphal (1990), p.44], and trade scholar Wontak Hong echoed that export policies were not "designed to discriminate among industries" (Hong 1977, 28).

After 1973, South Korean industrial policy targeted discrete heavy industry and the central policy tool was directed credit (S.-C. Lee 1991). Woo (1991) summarizes, "[t]he main goal of Korea's finance was to hemorrhage as much capital as possible into the heavy industrialization program" [p.159]. During the period, half of all domestic credit consisted of subsidized "policy loans," allocated by both commercial deposit banks and nonbanking financial institutions (e.g. credit unions) (Koo 1984; Woo 1991; J.-W. Lee 1996). Broadly defined, these Korean "policy loans" advanced government objectives, and had lower interest rates and were automatically re-discounted by the central bank at a preferential rate (S.-C. Lee 1991). ${ }^{5}$ During the HCI period, policy loans had longer repayment periods and average interest rates were 5 percentage points lower than other loans (Yoon-Je Cho and Kim 1995). This changed with the liberalization of the banking sector after 1979. Special rates on policy loans were eliminated by the early 1980s and took qualitatively different forms, largely promoting horizontal policies in the 1980s (Yoon-Je Cho and Kim 1995).

Figure 2 illustrates the shift from sector-agnostic IP (pre-1973) to HCI-specific policy (post-1973) by a major state lender, plotting the change in loans issued by the Korea Development Bank (KDB), where around 90 percent of policy loans from non-banking financial institutions emanated from (Yoon-Je Cho and Kim 1995, 42). Panel B presents the real value of all new KDB loans by industry, and Panel C shows new loans specifically for equipment, a focus of HCI policy lending. The thin light lines correspond to 2-digit industries, and thick lines are averages for HCI-targeted (red) and non-HCI-targeted (gray) industries. Panels B and C both reveal a rise in new credit to HCI sectors after 1973 and the decline in direct state lending after 1979. A large share of HCI lending was also conducted through conventional commercial banks, and Appendix Figure A1 shows a similar pattern in lending by more traditional banks. Although technically private, the sector was deeply intertwined with the state throughout the Park era, disseminating 60 percent of policy loans during the 1970s (The World Bank 1993; Yoon-Je Cho and Kim 1995). Panel A of Appendix Figure A1 shows that before HCI, the value of new loans from commercial deposit banks was similar across sectors, but rose sharply for targeted

${ }^{4}$ South Korea's five-year development plans have expressed diverse development strategies. Earlier plans emphasized broad strategies, and projects in the service of aggregate goals (Yoon Je Cho 1989, 93). The HCI Plan's "engineering approach" to sectoral development was unique. HCI effectively reoriented the aborted Third Five-Year Plan (1972-1976), fully articulating heavy industrial goals with a new ambitious, sector-specific planning administration (See H.-A. Kim 2004, Ch.8 for overview of the HCI planning). Later plans, for example under Chun Doo-hwan (1982-1986), were antithetical to this and emphasized liberalization.

${ }^{5}$ These loans were designed to advance government policies and were funded through deposit money banks and central bank credit. Although policy-based loans served other objectives throughout Korean history, such as rural development and infrastructure, they constituted a key part of directed lending to $\mathrm{HCI}$ during the drive. 
sectors after 1973. After 1979, new total heavy industry lending dipped, but in contrast to the KDB, total private bank lending continued. However, these post-1979 policy loans were different, where liberalization removed preferential rates and equalized borrowing costs across industries (Woo 1991, 196; S.-C. Lee 1991, 443-44).

Tax incentives also tracked the sectoral bias of Korean industrial strategy, moving from general export promotion to targeted policy. Panel A of Figure 2 tracks the sectoral bias of tax incentives before, during, and after HCI, and plots the estimated effective marginal tax rates by industry. These estimates account for a myriad of period-specific tax incentives, notably tax incentives for investment (e.g., investment tax credits and special depreciation rates alike) (Kwack 1985; Stern et al. 1995; J.-W. Lee 1996). ${ }^{6}$ After 1973, rates across industries in Panel B diverged. During HCI, the general export incentives of the earlier era "no longer played a central role compared to that played by [the] industry incentive scheme" [Trela and Whalley (1990), p.19. Tax laws were refocused to concentrate investment in heavy industry (Kwack 1984; J. H. Kim 1990). Initiatives like the "Special Tax Treatment for Key Industries," under the Tax Exemption and Reduction Control Law, gave strategic industries the choice of either five-year tax holidays, an 8 percent tax credit toward machinery investment, or 100 percent special depreciation allowances (J.-W. Lee 1996, 395). After 1979, Figure 2 shows the convergence in tax incentives during the retrenchment of HCI.

In terms of trade policy, the heavy industrial drive ended the pre-1973 "virtual free trade regime" among exporters. Post-1973, HCI-targeted industries enjoyed 1960s-style assistance and exemptions (Woo 1991; Yoon-Je Cho and Kim 1995). Where policy exempted any exporter from import restrictions on inputs (C.-H. Nam 1980; Westphal 1990), HCI producers were exempted from up to 100 percent of duties and tariffs on imports. Park (1977) estimates that "key industries," on average, enjoyed 80 percent tariff exemptions across industries (p.212). Even though trade policy reflected the turn to heavy industry, overt protectionism does not appear to be a major policy lever during HCI. I demonstrate this for post-1973 policy in Section 6.2. Before 1973, HCI-targeted industries were relatively unprotected under the export regime of the 1960s, even though Park desired a heavy industry sector. Output market protection was substantially lower among HCI sectors. Appendix Table A2 presents the differences in output market protection for 1968 for both quantitative restrictions and tariff rates. The level of protection for HCI is significantly lower than for other manufacturers (Also see the distributions of tariffs and quantitative restrictions in Figure D3 for 1968).

Park's assassination in 1979 prompted the withdrawal of HCI and a period of economic liberalization. South Korea dismantled HCI incentives, pursuing "investment adjustment" for HCI industry, and further accelerating trade liberalization (E. M. Kim 1988; K. Kim and Leipziger 1993; K. S. Kim 1994). The import liberalization ratio climbed from 68.6 in 1979 to 76.6 by 1982. Restrictions were further reduced between 1982 and 1984. The banking sector was also liberalized, with notable reforms in 1981 and again in 1983. The share of government "policy loans" to industry shrank (Yoon-Je Cho and Cole 1986; S.-W. Nam 1992). By 1982, the gap in effective marginal corporate tax rates between strategic and non-strategic industries was eliminated (Kwack and Lee 1992).

D) Summary: Historical Context as a Natural Experiment. The context of HCI detailed above informs the design of this study and I now summarize key advantages:

- i) First, the setting introduces clear temporal and sectoral variation. HCI was a shift in national policy toward a discrete set of nascent heavy industries. The policy shift began and ended because of external political events: the Nixon Doctrine and Park's assassination. The political catalyst for HCI shifted Korea from horizontal IP (export-first policy) to targeted policy (HCI). The liberalization of HCI is important, as theoretical justifications rarely encompass the eventual scaling back of policy (Kaneda 2003; Juhasz 2018).

${ }^{6}$ The Online Appendix describes the calculation of the marginal tax estimates. These estimates by Kwack (1985) assume that firms fully avail of tax policies. These policies include the corporate tax rate, the investment tax credit rate, the depreciation rate under national tax law, and policy-specific tax reductions and exemptions (for each period). 
- ii) IP variation was purposeful. HCI was an actual policy and not random variation mimicking IP. Given the complications of estimating the impact of IP, researchers have used important natural experiments that mimic policy variation (Juhasz 2018; Hanlon 2020; Mitrunen 2019). Nevertheless, the case for IP hinges on policy being intentional. This rationale can make it difficult to glean insights from some forms of random variation across units (Rodrik 2004). ${ }^{7}$

- iii) Although targeted, stakeholders did not believe HCI would develop without intervention and debated whether HCI would benefit from intervention. Multiple Western lenders chose not to lend to $\mathrm{HCI}$, arguing that heavy industry was unlikely to become competitive under this policy. They argued, instead, that Korea's comparative advantage lay in labor-intensive manufacturing. Korean planners countered that intervention could create comparative advantage in treated sectors, using Japan as an example. Both sides agreed that without intervention, Korea was unlikely to achieve dominance in HCI. However, Korea believed that the targeted sectors would be responsive to intervention.

- iv) The political context of HCI reduces the role of political confounders. The HCI setting meant industrial policies were binding and coherent. Clientelism and political demands often divert IP to industries that suffer comparative disadvantage (Rodrik 2005; Lin 2012). Even where sectoral choice is coherent, political constraints can undermine the quality of policy administration. Policy estimates may reflect political failures rather than the impact of optimal policy. For HCI, IP was driven by topdown shifts in national industrial strategy, and the sectoral bias was not driven by the demands of competing constituencies. Furthermore, the political economy of the program meant policy was incentive compatible.

\section{The Conceptual Case for Industrial Policy and Empirics}

I now summarize the conceptual cases for industrial policy and turn to two prominent externalities relevant to the HCI episode: dynamic economies and linkage effects. The theoretical justifications for IP are vast relative to the empirical evidence (Krueger and Tuncer 1982). Neoclassical justifications for IP interventions often rely on the existence of externalities (Corden 1997; Kaneda 2003). The sources of these externalities are numerous, such as industry-level knowledge spillovers, scale economies, IO linkages, local labor market spillovers, and more (see Harrison and Rodriguez-Clare 2009; Grossman 1990; Rodrik 1995b; Corden 1997). I consider two prominent externalities and their empirical implications for this study.

A) Dynamic Economies. Dynamic externalities have been a key justification for IP (Bardhan 1971; Succar 1987; Young 1991; Redding 1999). Here, time and externalities are the critical ingredients (Corden 1997). ${ }^{8}$ Of this class of externalities, intra-industry learning-by-doing externalities have played a prominent role. These learning-bydoing spillovers occur when firms accumulate production experience and this produces industry-wide reductions in production costs. In this setting, firms fail to internalize the benefits to learning and under-produce relative to what is socially efficient. Thus, these forces are a classic justifications for IP interventions, for example, where industry policy helps infant industry mature by realizing dynamic returns.

In addition, interventions can also be justified in settings where learning-by-doing occurs within a single firm, rather than across firms. In presence of firm-level learning-dynamic internal economies-imperfect capital markets (or imperfect information) can also theoretically justify interventions (Lucas 1984; Succar 1987; Corden 1997). With firm-level learning, imperfect capital markets mean that infants are unable to finance themselves through the costly early periods of learning.

\footnotetext{
${ }^{7}$ Key studies by Criscuolo et al. (2019) and Giorcelli (2019) illustrate using random variation in ways that recover policyrelevant estimates.

${ }^{8}$ Forms of dynamic externalities are numerous. For example, industries may become more productive over time as pools of labor acquire skills (Hanlon 2020), production knowledge spills over (Rodriguez-Clare 2007), technological complementarities are realized (Rosenberg 1976), and more.
} 
Dynamic economies of scale are the means by which industrial policy can, in theory, cultivate dynamic comparative advantage in trade (Redding 1999). If learning-by-doing conditions are suitable (i.e. intra-industry dynamic externalities or firm-level learning by doing with incomplete capital markets) and strong, successful infant-industrial policy in new sectors can promote the evolution of its comparative advantage on the international market.

Empirically, IP in these environments means should correspond to the evolution of targeted industries, measured by improvements in industrial development outcomes over time, such as industrial expansion, or more importantly, higher productivity (Lucas 1984). Where learning-by-doing forces are strong enough, these effects may manifest in improved comparative advantage for these industries. I explore these outcomes in Section 5.1. More directly, however, the econometrician could observe changes in outcomes directly related to dynamic externality mechanisms, such as measures of learning by doing, which I study in Section 6.

In light of these mechanisms, correlational studies have argued that IP does not correspond to industrial development. For Korea, J.-W. Lee (1996) identifies a negative relationship between postwar IP interventions and industry-level outcomes, specifically, protection and manufacturing productivity. Dollar and Sokoloff (1990) also identify low productivity in heavy industries during the HCI period, relative to labor-intensive sectors. Other studies of East Asian economies have determined a negative relationship between interventions and industrial development outcomes. Important research by Beason and Weinstein (1996) argues that IP was not positively related to industrial development in Japan nor was it directed at sectors with static economies of scale. Others have argued that IP failed to positively impact South Korea's comparative advantage. Yoo (1990) argues that HCI may have, in fact, harmed South Korea's export development performance relative to its contemporaries.

B) Linkage Effects. The existence of pecuniary externalities has been another justification for industrial policy (Krueger and Tuncer 1982; Grossman 1990; Krugman 1993). Here, price effects and benefits are conferred on sectors that are not directly targeted. The existence and strength of these potential externalities have long formed a fundamental justification for IP. Development economists have long considered how industrial interventions impart benefits beyond the direct targets of the policies through IO linkage (Scitovsky 1954; Rasmussen 1956; Hirschman 1958).

The argument is intuitive--targeting is likely justified where the social benefits conferred to others are large. These benefits are transmitted in two directions. The first is through backward linkages to upstream industries selling inputs to targeted sectors. For example, if IP increases the scale of targeted industries, it should confer benefits through the demand channel. Second, IP can confer benefits through forward linkages to downstream industries purchasing inputs from targeted sectors. For example, if IP increases the productivity of a treated industry, it may lower the price of its output to the benefit of domestic consumers.

As with dynamic externalities, tests of IP justifications with linkage spillovers have attempted to explore the relationship between targeting-or often, policy levers—and the existence of linkage spillovers. Incisive studies of East Asia in particular have rejected IP on the grounds that it has not corresponded to these externalities. For example, Noland (2004) argues that Korean policy did not target sectors with high spillovers (linkages). Using measures of IO linkages, Pack (2000) finds industries targeted by South Korea and Japan had low linkages with nontargeted industries and questions whether the policy targeted externalities. These criticisms are closely related to the study by Beason and Weinstein (1996), who consider that targeted Japanese industries, measured through various instruments, did not correlate with static scale economies.

Taken together, Noland and Pack (2003) and Pack and Saggi (2006b) thus argue that industrial development and targeting seem uncorrelated with growth in key historical episodes. This reinforces the critique that states may not have the expertise to deploy IP. However, a recent applied theoretical study by Liu (2019) reveals that common features of IO tables may correspond to optimal targeting. Moreover, using data from this study, Liu 
(2019) demonstrates that Korean as well as Chinese targeting may in fact correspond to optimal targeting. This study seeks to test for the existence of these forces, dynamically.

\section{Data}

I construct new industry-level data on industrial development during South Korea's miracle period, 1967-1986. presents pre-1973 statistics (mean and standard deviation) for key variables. For readability, A3 reports nonnormalized values. Through this study, I default to the inverse hyperbolic sine (or ihs) normalization, which notably accommodates zeros. Variables, such as disaggregated investment data or RCA (discussed below), contain zeros; inventories contain both zeros and negative values.

A) Long and Short Panels. Industry-level panels are constructed using digitized data from the EPB's Mining and Manufacturing Surveys and Census (MMS). MMS data are suitable for studying HCI, which was fundamentally a sectoral policy. The MMS is high quality, reports manufacturing census outcomes across the study period, and importantly, is available at fine, industry-level disaggregation. The EPB published census data nearly every five years (with annual intercensal surveys) at the 5-digit industry level, aggregated from establishment-level enumeration.

I supplement digitized MMS statistics with MMS tape data (1977-1986) sold by the EPB in the 1980s. Additional data on prices are digitized from historical and contemporary Bank of Korea producer price index publications.

Creating consistent industry panels, however, is not simple. Tracking industries through the study period requires concordance and harmonization across many code revisions. Between 1967 and 1986, the EPB updated Korea's industrial codes (KSIC, based on the international ISIC standard) four times, with a major revision in 1970. The harmonization process required over a dozen crosswalk schemas. This process entailed digitizing and rebuilding official crosswalks, which are detailed in the Online Data Appendix.

This study uses two harmonized panels, shown in Table A3. Part A of Table A3 reports values from the "short" granular 5-digit industry panel, which is harmonized from 1970 to 1986 Part B reports values from the "long" more aggregated 4-digit panel, harmonized from 1967 to 1986. The terminal date of the study is 1986, the year before a disruptive democratic transition in 1987.

The harmonization process introduces a trade-off between the two panels. The short panel (1970-1986) accommodates more industry observations (5-digit level) but does so over a limited period. This shorter panel requires less harmonization and is closer to the original MMS publication statistics. By contrast, the long panel (1967-1986) contains fewer industries (4-digit level) over a longer period. Thus, the longer panel requires more harmonization—and aggregation-but covers the critical pre-1973 years. Although the long (4-digit) panel adds three years to the set of pretreatment years (data starts in 1967 vs. 1970), the harmonization process means the panel contains a third (approximately 88) of the sectors of the granular short (5-digit) panel.

B) Defining Treatment. Section 2 explained the sectoral scope of HCI, which made use of six main sectoral acts. For this study, the targeted industries are those that closely match these laws. For sectors such as shipbuilding, both aggregate sectors and granular industries are closely aligned. Care is required for more complex sectors, such as chemicals.

I match the industries that appear in the legislation (Section 2) to the harmonized data, both long and short panels. Online Appendix Table 1 provides a sample of translated harmonized industry strings (5-digit) that fall under the treated categories. Note that industry names are "synthetic" or representative names-Englishlanguage strings that best fit a harmonized industry. Because of the harmonization of industry classifications, multiple treated industries may fall under a "synthetic industry." The strings are a summary description of 
these sectors, which may be heterogeneous. I perform a similar matching procedure for IO tables and trade data.

C) Linkages. Inter-industry linkage data are constructed from the Bank of Korea's 1970 “basic" IO tables. These are the most disaggregated tables for the period, covering approximately 320 sectors. Hard copy tables were translated into English and then digitized. ${ }^{9}$ I use these direct flow tables to calculate Leontief IO coefficients. From these tables, I construct linkage measures to and from HCI-targeted industries, which I describe in Section 7.

The Bank of Korea data and MMS surveys use different coding schemes. Thus, combining IO accounts with industry data requires further harmonization. I describe the process and other harmonization in the Online Data Appendix.

Furthermore, the basic 1970 IO tables report total values of inter-industry trade flows and do not distinguish between domestic and imported activity. I supplement the study's baseline 1970 IO tables with 1975 IO tables. Though produced during the HCI period, the 1975 accounts distinguish between domestic and imported intraindustry flows. I return to this distinction in the network analysis in Section 7. Unless otherwise specified, I refer to the baseline, or "general", 1970 linkages.

D) Trade Data and Trade Policy. I also use international trade flow and trade policy data. The "long" 4-digit industry panels are hand matched to Standard International Trade Classification (SITC, Rev. 1) 4-digit-level trade data. The trade flow data come principally from the UN Comtrade database

Trade policy - product-level measures of quantitative restriction (QRs) coverage and tariffs-are digitized from Luedde-Neurath (1986) (at the Customs Commodity Code Number level). This data is available for 1968, 1974, 1976, 1978, 1980, and 1982. This is the most disaggregated readily available data for the period (Westphal 1990). These statistics contain measures of core non-tariff barriers, notably QRs (Goldberg and Pavcnik 2016). Most empirical studies of Korean trade policy use highly aggregated data. For QRs, Luedde-Neurath (1986) codes the severity of restrictions from least to most severe (0 to 3 ).

I use trade policy data to calculate separate measures for output and input market protection. ${ }^{10}$ Output protection for industry $i$ is simply the average tariff or QR score for that sector: output-tariff $i$. used exemptions from import barriers as a policy tool; thus, I calculate measures of input protection. Input tariffs faced by $i$ (or QRs) are calculated as the weighted sum of tariff (QR) exposure, with weights taken from the 1970 IO accounts (following Amiti and Konings (2007)). As such, exposure is calculated as input-tariff $i_{i}=\sum_{j} \alpha_{j i} \times$ output-tariff $_{j}$, where $\alpha_{j i}$ are input cost-shares for industry $i$.

\section{Direct Impact of Industrial Policy}

I discuss the impact of policy on industries directly targeted by the HCI drive in three steps. First, I introduce the main estimation strategy (Section 5.1) and use this to identify multiple ways in which HCI targeting corresponds to industrial development (Section 5.2). Second, I reveal patterns of industrial development using a double-robust DD estimator and report estimates for the total average impact of policy (Section 5.3). Last, I employ a DDD estimation strategy to determine the impact of HCI on Korean industry using cross-country variation (Section 5.4).

\footnotetext{
${ }^{9}$ At the time of this study, "basic" machine-readable IO tables for 1970 were not available from the Bank of Korea.

${ }^{10}$ For simplicity, this study follows the contemporary practice of using nominal statutory measures, although I also calculate measures weighted by input share for the corresponding year.
} 


\subsection{Estimation}

A) Main Estimation Strategy. I use the temporal and sectoral variation from the HCI drive to estimate the impact of HCI using a differences-in-differences strategy. I take the January 1973 announcement of HCI as the start date, and the assassination of President Park in 1979 is the de facto end date. I compare differences between the set of targeted manufacturing industries versus the set of nontargeted manufacturing industries relative to 1972. I consider the baseline specification to be as follows,

$$
Y_{i t}=\alpha_{i}+\tau_{t}+\sum_{j \neq 1972} \beta_{j} \cdot\left(\text { Targeted }_{i} \times \text { Year }_{t}^{j}\right)+\sum_{j \neq 1972} X_{i}^{\prime} \times \operatorname{Year}_{t}^{j} \Omega_{j}+\epsilon_{i t}
$$

where $Y$ is an industrial development outcome, subscript $i$ indexes each manufacturing industry, and the year is denoted by $t$, taking the values 1967-1986 for the long panel and 1970-1986 for the short panel. Equation (1) is a linear TWFE specification, with industry fixed effects $\alpha_{i}$ and time effects, $\tau_{t}$. Standard errors are corrected for heteroskedasticity and are clustered at the industry-level, allowing for within-industry correlation. Equation (1) includes baseline pretreatment variables to control for unobserved productivity correlated with the intervention. These controls include average total material costs (total material outlays per worker), the average wage bill (total wage bill per worker), the average plant size (employment per plant), and value added per worker. Since these outcomes are averaged over the pre-period, $X_{i}^{\prime}$ does not change through time, and I estimate their impact by interacting them with period effects.

The impact of HCI is estimated using a binary variable Targeted, equal to one for a treated (or targeted) HCI industry and zero otherwise (Section 4). The set of $\beta_{j}$ s are the differences between targeted and nontargeted industries for each year $j$, relative to the pre-treatment year 1972. Coefficients for 1972 are normalized to zero. This "sharp" treatment term allows me to visually assess counterfactual dynamics by clearly plotting pretrends and group averages. I also compare TWFE estimates from eq. (1) with the doubly robust DD estimators below, which requires binary treatment.

Coefficients of interest, $\beta_{j}$, convey three aspects of how HCI sectors evolved. First, estimates after 1972 describe the average impact of the targeting for each period after the start of HCI. If HCI is associated with short-term industrial development during the (six year) policy period, we should observe increasing differences in $Y$ between 1973 and 1979

Second, estimates after 1979 describe the long-term impacts of HCI. In the parlance of the IP literature, the longevity of these effects indicates the potential "dynamic effects" of IP. This evolution of industry may be realized through dynamic economies of scale (Section 3), notably learning by doing. Note that even where differences stabilize in the post period, this may also coincide with a permanent shift in levels of development between the two industries.

Third, estimates before 1972 describe average differences between HCI-targeted and non-HCI-targeted industries before the policy. Thus, they convey information about the common trend assumption of the research design. Before 1972, we should not observe systematic differences between treated and control industries: $\hat{\beta}_{1967} \approx$ $\hat{\beta}_{1968} \approx \hat{\beta}_{1972} \approx 0$. For key estimates, event study tables provide tests of joint significance for pre-period estimates. ${ }^{11}$

The goal of eq. (1) is to understand the impact of HCI on treated industries or the average treatment effect on the treated (ATT). This is specifically relevant for IP, where we are often interested in the impact of policy on the particular industries subjected to treatment. This estimand is different from the more general ATE on any

${ }^{11}$ Neither individual nor joint significance tests are conclusive. Although null results provide information about DD pretrend assumptions, they cannot verify the pre-trend assumption. This may be true, in particular, of the "detailed" 5-digit estimates used in my study, which have limited pretreatment periods. 
industry, where assumptions are stricter. Crucially, estimating the ATT requires that the common trend assumption holds.

Nevertheless, common trend assumptions may address this issue under the assumption that this form of selection does not change over time, irrespective of policy. In this circumstance, the common trends eliminate this form of selection between targeted and nontargeted industries (Heckman et al. 1998; Blundell and Dias 2009). In the context of HCI, the parallel trends assumption removes unobserved idiosyncratic gain from IP if the bias remains unchanged between the sectors at the time of treatment.

However, IP such as HCI are targeted at sectors that may stand to benefit most from the policy. ${ }^{12}$ In these cases, treated industries may be those that achieve "idiosyncratic gain" from the policy. In this study's setting, HCItargeted industries may be those expected to respond the most to the policy, for example, by virtue of having strong dynamic economies. The common trend assumption addresses this issue under the assumption that this form of selection does not change over time, irrespective of policy. If this assumption holds, common trends eliminate this form of selection between targeted and nontargeted industry (Heckman et al. 1998; Blundell and Dias 2009). Thus, the parallel trends assumption removes unobserved idiosyncratic gain from IP if the bias remains unchanged between the sectors at the time of treatment. If unobserved productivity is expected to accelerate in HCI-targeted industries regardless of treatment, this assumption is violated. ${ }^{13}$ Therefore, estimating the impact of HCI on treated industries requires a proper control group, and the treatment effects literature has emphasized the power of reweighting-style estimators (Heckman et al. 1998; A. Smith and E. Todd 2005).

With these econometric issues in mind, I go beyond the baseline TWFE analysis in two ways. First, I use a "doubly robust" DD estimator, a method that both re-weights observations in the control group through their propensity score and adjusts the counterfactual outcome using a linear regression model (Section 5.3). Second, I estimate the takeoff of Korean HCI-targeted industries using cross-country (and cross-industry) variation and a DDD estimator (Section 5.4). The triple difference strategy attempts to directly address the issues discussed above by comparing Korean industries to similar international industries.

\subsection{Direct Impact Results: Core Patterns of Industrial Development}

A) Output Expansion and Key Patterns. Figure 3 plots dynamic DD estimates (TWFE) for the impact of HCI on output, measured as real value shipped. Coefficient estimates from eq. (1) are in black, and the 95 percent confidence intervals are in gray. Panel A provides estimates for the detailed ("short") 5-digit panel, which starts in 1970. Panel B presents estimates for the more aggregated ("long") 4-digit panel, which starts in 1967. The columns provide estimates taken from estimates from the specifications with a baseline fixed effect (right) and from those with controls (left).

The top row of Figure 3 presents the mean output for HCI-targeted (red) and non-HCI-targeted (black) industries separately. These are averages for treated and nontreated sectors from model (1). The bottom row of Figure 3 shows the DD plots, or the estimated differences between the treated and non-treated. The corresponding tables are given in Online Appendix Table 2, along with the tests for joint significance for pre-trends.

Figure 3 presents three key patterns of industrial development associated with the HCI drive, and similar patterns will reappear across outcomes throughout. First, consider the pre-HCI period, 1967-1972. Figure 3 shows that output from HCI-targeted and nontargeted industries evolved similarly. This is clearest in the long aggregate 4-digit data. Pre-1973 estimates are virtually zero. Pre-period coefficients are, individually, insignificant, and the F-tests in Online Appendix Table 2 reveal that they are also jointly insignificant.

\footnotetext{
${ }^{12} \mathrm{IP}$ shares similarities with place-based (spatially targeted) policies (Neumark and Simpson 2015), where the source of bias is in the opposite direction: grants are often aimed at lagging areas.

${ }^{13}$ Section 2 part D argued that Korea and potential lenders thought this was unlikely. Neither expected Korea to be ascendant in terms of HCI-targeted industries without heavy intervention.
} 
Second, Figure 3 demonstrates that marked differences between treated and nontreated sectors emerged after the 1973 intervention. During the HCI drive period, relative to 1972, these differences widen and become salient. This divergence is starkest in estimates for the 5-digit data in Panel A, and Panel B reports similar divergence for aggregate data, which are mostly significant during the HCI drive period.

The top row of Figure 3 highlights the importance of the counterfactual manufacturing industries used in the DD strategy. The estimated differences shown at the bottom of 3 do not appear to be driven by a decline in the control industries. This is useful, as differences between treated and nontreated industries can emerge if policies harm control industries while failing to promote the expansion of treated industries. ${ }^{14}$

Third, Figure 3 shows that the impacts of the HCI period were not transitory. For the liberalization period, post1979, HCI-targeted and non-HCI-targeted industries are still significantly different in terms of the value of output production relative to 1972 levels. After the fall of HCI and the Park regime, estimated differences diminish and become noisier. The top row of Figure 3 also reveal that even though differences stabilize (or diminish), the level effects may be permanent. ${ }^{15}$

The patterns above are robust. Online Appendix Figure 3 shows that estimates in Figure 3 are similar across three measures of output, across data sets (4-digit v. 5-digit panels), and across specifications (baseline v. controls). See Online Appendix Table 2 for full regressions.

B) Industrial Development. Figure 4 shows the impact of HCI across industrial development and trade development (e.g., revealed export productivity and comparative advantage) outcomes. The top rows of Panel A of Figure 4 illustrate that HCI coincided with a significant increase in simple measures of labor productivity (real value added per worker) and relatively lower output prices. These estimates are more precisely estimated in 5digit data, with strong estimates throughout the duration of the program, whereas estimates are less precise for aggregate 4-digit data. Appendix Figure B1 shows that the labor productivity estimates are indeed driven by a rise in labor productivity for targeted industry. The top row of Appendix Figure B1 Panel A (5-digit panel) shows that the trends between the two industries are similar throughout the mid-1970s and diverge during the policy period. Labor productivity rises through the HCI period, which is notable in the 5-digit data and less precisely estimated in the 4-digit data.

A naive reading of the event study estimates in Figure 4) may indicate that prices declined for HCI versus nonHCI or that pre-1973 "pre-trends" imply a literal downward trend in prices for HCI-targeted industries. However, the story is more subtle. Prices in Appendix Figure B1 Panel B show that average prices grew markedly during the inflationary 1970s, yet HCI prices broke with the control industry averages and were relatively lower over the period. The price effects in Figure 4 and Appendix Figure B1 contrast with IP experiences elsewhere, where inefficient IP has increased the prices for targeted outputs. A positive relationship between prices and IP may be the norm rather than the exception. For example, in Egypt, India, and Turkey, heavy IP may have effectively increased the relative price of capital and intermediate goods (Schmitz Jr (2001); see Blonigen (2016) for the case of steel).

Panel A of Figure 4 shows a significant rise in the number of plants operating in HCI markets. Estimates for plant activity are highly significant, starting after 1973. Although positive, these estimates are less precise in the 4-digit data. Note that size pertains to plant—not firm-size. Since MMS is aggregated at plant level, I do not analyze firm-level measures. As well, the bottom row of Panel A (Fig. 4) demonstrates that HCI coincided with a substantial shift in the share of industrial activity to HCI-targeted industries and a rise in industrial employment, both in share of manufacturing employment and share of manufacturing output. In the HCI

\footnotetext{
${ }^{14}$ Cerqua and Pellegrini (2017) shows such effects for Italian place-based policy.

${ }^{15}$ In 1972, the average real value of output shipped was 91,070 and 72,607 (thousand won, 2010) for non-HCI and HCI industry, respectively. By 1982, after differences stabilized, these averages were 332,131 and 570,784 for non-HCI and HCI industry, respectively.
} 
post-period, the share of economic activity in $\mathrm{HCI}$ is durable, although estimates are less precise for aggregate data. The F-tests in Online Appendix Table 3 identify no pre-trends for the reallocation of activity.

C) Trade Performance and Export Productivity. Export performance was central to HCI's goal of industrial transformation. For example, a target of the drive was to attain a 50 percent share of HCI exports by 1980 (World Bank 1987; Hong 1987). Panel B of Figure 4 focuses on export development using SITC (Rev. 1, 4-digit) trade flow data, which are substantially more disaggregated than the 4-digit KSIC industry panels.

For each Korean industry, I estimate the relative export productivity using the methods proposed by Costinot, Donaldson, and Komunjer (2012) (CDK, henceforth), who propose a regression-based measure of relative productivity. ${ }^{16} \mathrm{CDK}$ estimates provide a theoretically consistent measure of revealed comparative advantage, beyond conventional RCA calculations (described below). For industry $k$, I estimate relative productivity for country $i$, where $\widehat{C D K}_{k}=\exp \left(\delta_{i k} / \hat{\theta}\right)$. The $\delta_{i k}$ term the exporter-commodity fixed effect from the bilateral trade regression, $\ln \left(X_{i j k}\right)=\delta_{i j}+\delta_{j k}+\delta_{i k}+\epsilon_{i j k}$, where $X$ are exports, $i$ is an exporter, $j$ is an importer, and $k$ is a commodity. The trade elasticity $\hat{\theta}$ is 6.53 via Costinot, Donaldson, and Komunjer (2012).

The traditional RCA (Balassa 1965) is measured as the share of exports for a Korean product relative to the world's share of exports of that same product. ${ }^{17}$ If Korea's $R C A_{k}$ for product $k$ is greater than one, Korea has a comparative advantage in that market.

Panel B in Figure 4 reports a strong positive relationship between IP and relative productivity (CDK) and traditional RCA for treated exports. Estimates across the RCA measures demonstrate a consistent pattern across three measures (the untransformed RCA, ihs-normalized, and CDK). Trade-related measures in Panel B are estimated using the Poisson pseudo-maximum likelihood (PPML), as opposed to ordinary least squares (OLS), in line with the trade literature.

First, after 1973, there is a marked rise in the relative RCA and share of manufacturing exports for targeted SITC industries. The probability of attaining RCA (RCA > 1) grows markedly after 1973. Second, before 1973, pre-trends are absent across trade development outcomes, with the exception of RCA (ihs), which is trending downwards. Third, estimates grow and become highly significant right around the time of liberalization. In general, relative comparative advantage emerges during the drive and is fully articulated after the HCI period.

\subsubsection{Direct Impact Results: Robustness and Total Factor Productivity}

A) Total Factor Productivity. Thus far, I have considered more indirect measures of productivity. I now turn to TFP, although contemporary best practice for estimating TFP has focused on micro-estimates (Van Beveren 2012). Among other things, the industry-level data used in this study can be problematic. For example, aggregation may limit the power to estimate production function parameters and may exacerbate the measurement issues that confound TFP (see Diewert 2000), and problems such as market imperfections complicate estimates of TFP for miracle economies specifically (Felipe 1999; Fernald and Neiman 2011). Nevertheless, I now consider TFP.

Figure B2 shows the estimates for the impact of HCI on industry-level TFP, where TFP is estimated using baseline OLS (fixed effects), Olley and Pakes (1996) (OP), Levinsohn and Petrin (2003) (LP), and Ackerberg, Caves, and Frazer (2015) (ACF) as well as Wooldridge (2009) (W) methods. Production function parameters are estimated at approximately 2-digit level for power. ${ }^{18}$ To be conservative, I use 1970 as the baseline for TFP

\footnotetext{
${ }^{16}$ I thank an anonymous referee for this suggestion.

${ }^{17}$ Using the Balassa (1965) definition, as the ratio of Korean export-share $\left(X_{k}\right)$ for industry $k$, relative to the world's export share: $\mathrm{RCA}_{k}=\left(X_{k}^{\text {Korea }} / X_{\text {Total }}^{\text {Korea }}\right) /\left(X_{k}^{\text {World }} / X_{\text {Total }}^{\text {World }}\right)$.

${ }^{18}$ For power, some sectors with few observations are combined. For example, the mining and minerals sectors, which contain limited 5-digit observations, are combined into an aggregated 2-digit industry. I follow TFP studies and Winsorize estimates for extreme values.
} 
estimates. Figure B2 demonstrates that 1972 was a particularly low year for HCI TFP and DD estimates; using 1972 as the baseline can overstate post-1972 TFP growth.

Figure B2 shows a slow upward trend in TFP for HCI-targeted industries relative to non-HCI-targeted industries. However, there is significant heterogeneity across the five methods, and estimates are noisy. For the preperiod data, TFP in the HCI-targeted industries seemed stagnant prior to 1973, perhaps even declining After 1973, this trend reverses, with estimates picking up steam through the later 1970s. Across the measures, estimates for TFP become significant post-1979. Although earlier studies have stressed that HCI-targeted industries experienced low productivity growth (Dollar and Sokoloff 1990), they do not account for trends in TFP. Slow relative growth during the period matches prior estimates for the period (Felipe 1999); however, the trajectory is upward rather than downward. Both these effects seem compatible with a story of industrial learning taking time.

B) Post-HCI Persistence in Plant-Level TFP. Turning to microdata estimates of TFP for the post-1979 period, I find that there are persistent positive effects on the relative TFP of treated establishments. Microdata estimates indicate that the results above are likely not an artifact of industry-level TFP estimation. Plant-level data are available from 1980 onward and I use these data to provide correlational evidence for TFP in the post-HCI period. First, Table 1 considers a cross section of TFP for HCI plants versus non-HCI plants during the post1979 period. I regress plant TFP on an indicator dummy variable equal to one if a plant is operating primarily in an HCI-targeted industry and use zero otherwise. I include Industry $\times$ Year effects (4-digit industry by time shocks). Plant fixed effects absorb HCI indicators and are excluded. I use two-way clustered standard errors at the 4-digit-industry and establishment level.

Second, across all measures of TFP, Table 1 shows that HCI plants have significantly higher TFP than non-HCI plants. TFP estimates are 2-8 percent higher for HCI-targeted industries than for non-HCI-targeted industries, depending on the TFP estimation method and specification. Appendix Figure B3 illustrates the (relative) productivity dynamics compatible with the industry-level dynamics described above (Figure B2). Appendix Figure B3 provides the plant-level event study-like estimates, using 1980 as the baseline year. Specifications here are similar to the baseline specification in eq. (1), but with establishment fixed effects and year effects. Across TFP estimates, there is a slight trend in the relative TFP for HCI plants during the 1980-1986 period.

C) Continuous HCI Treatment and Limited "Horizontal" Spillovers. I now consider the patterns of industrial development using a continuous industry-level measure of "exposure" to HCI. For each 4-digit industry, supplemental MMS tables provide the value of output plants produced across 8-digit products, inside or outside the 4-digit industry. Consider a 4-digit industry. For firms operating primarily in that industry, the MMS reports the value of output across the 8-digit products. For multi-product plants, although most output falls within a "home" industry, output may spill over into products in other 4-digit markets.

Thus, I use 1970 data to construct a continuous industry-level measure that captures the share of product-level output (value shipped) going to either HCI or non-HCI markets. I do this using the feature of MMS data described above, which captures the extent to which a 4-digit industry is "exposed" or "spills over" into other markets. An industry's product-level exposure to HCI (or non-HCI) markets is calculated as the total value of products shipped to only HCI (or non-HCI) markets divided by the total output produced by firms in a 4-digit industry.

Figure B4 show results from specification (1) using this continuous HCI measure. The results mirror the pattern of the binary measures for the main development outcomes (Fig. 4) and output (Fig. 3). Figure B4 presents continuous estimates for shipments, labor productivity, prices, employment, and the share of manufacturing output. Binary and continuous treatment track one another, and there is strong overlap. The distribution in the share of product output is highly correlated with either HCI or non-HCI 4-digit industry, as shown in Online Appendix Figure 2. This demonstrates that there may be limited horizontal spillovers across the treatment; it 
appears that multi-product firms operating in 4-digit HCI-targeted industries did not also operate in non-HCI product markets, at least in the limited 1970 data (see Rotemberg (2017) for discussion).

\subsection{Direct Impact: Double-Robust DD Results and Average Effects}

A) Double-Robust DD Estimator. The next approach employs a doubly robust DD estimator proposed by Sant'Anna and Zhao (2020) and Callaway and Sant'Anna (2020), which has some advantages. First, a doubly robust estimator re-weights observations in the control group according to their propensity score and adjusts the counterfactual outcome using a regression model. Second, it relaxes some of the constraints of TWFE DD estimators, such as including covariates to satisfy the conditional parallel trends assumption. Third, it provides an interpretable overall ATE on treated units. ${ }^{19}$

I consider the following specification,

$$
\mathrm{ATT}_{t}=\mathbf{E}\left[\frac{\text { Targeted }}{\mathbf{E}[\text { Targeted }]}-\frac{\frac{\pi(X)(1-\text { Targeted })}{1-\pi(X)}}{\mathbf{E}\left[\frac{\pi(X)(1-\text { Targeted })}{1-\pi(X)}\right]}\right]\left(Y_{t}-Y_{1972}\right)-f_{0, Y_{t}-Y_{1972}}(X)
$$

where eq. (2) refers to the weighted average differences in industry outcomes. More precisely, eq. (2) is the difference in outcomes between targeted industries (Targeted) and nontargeted industries (1 - Targeted). Weights in eq. (2) are defined as follows (Sant'Anna and Zhao 2020; Callaway and Sant'Anna 2020). The

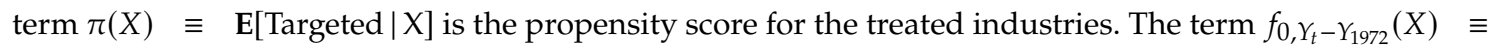
$\mathbf{E}\left[Y_{t}-Y_{1972} \mid\right.$ Targeted $\left.=0, X\right]$ is a regression for the change in outcomes for non-treated industries, between post-

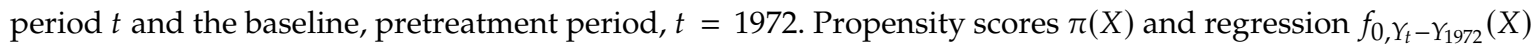
are estimated by logit and OLS, respectively. The estimator (2) is doubly-robust in the sense that if either component is correctly specified, then it is a consistent estimate of the ATT. Confidence intervals for (2) are calculated using a bootstrap procedure, allowing for autocorrelation and industry-level clustering (Callaway and Sant'Anna 2020). I use the same covariates as those used in the TWFE DD estimator above.

The two-step procedure relaxes the functional-form assumptions of the evolution of potential outcomes. The doubly robust estimation procedure ensures balance between targeted and nontargeted industries. The pre-trend assumptions are also less stringent than other estimators. The average effects in eq. (2) do not rely on zero pre-trends over all pre-treatment periods, and instead uses a long-difference (between post-period $t$ and the last pretreatment period, 1972).

Below, I demonstrate that the patterns estimated by linear TWFE estimation are similar to the doubly robust estimator above 1. For simplicity, I default to linear TWFE results for eq. 2 first and then give the corresponding estimates from eq. (2). Additionally, I report the total average impact of policy from the pre-post estimates. I show aggregate OLS (TWFE) estimates alongside aggregate doubly robust estimates. Note that specification 2 requires a binary treatment and is not used for cases of continuous treatment; this includes the later network analysis in Section 7.

B) Results: Main patterns. Figures B5-B7 provide estimates from the doubly robust estimator of Sant'Anna and Zhao (2020); Callaway and Sant'Anna (2020). The discussion above indicated that this estimator has the advantage, among other things, of creating a more consistent group of control industries. These plots show estimates of specification (2) across industrial development outcomes. Controls and specifications are

${ }^{19}$ Emerging literature documents why such linear estimates may be sensitive to a number of assumptions, such as heterogeneity of treatment and dynamic impacts of policy (Sloczynski 2018). In this study's setting, the impact of IP may vary over time. Similarly, the common trend assumption may hold only after the conditioning of covariates (Callaway and Sant'Anna 2020). Both factors can complicate direct interpretations of the total average effect of policy. 
comparable to the linear TWFE estimates above. They include the same set of pretreatment controls and standard errors clustered on the industries. Bootstrap confidence intervals are given at the 10 percent and 5 percent levels-light and dark gray, respectively.

Consider first the relationship between HCI and industrial development given by Appendix Figures B5 (4-digit panels) and B6 (5-digit panels). Similarly, Figure B7 reports estimates for export development outcomes aggregated to the 4-digit KSIC industry level. The patterns in Figures B5-B7 are qualitatively similar to the linear TWFE estimates. Although the doubly robust DD relaxes some assumptions related to the traditional TWFE DD, the general dynamic pattern associated with HCI is robust. This is important because this estimator reweights the treatment and control groups.

C) Results: Average Impact. Consider the overall average impact (specifically, the ATT) of the policy before and after 1972, which is also shown in Appendix Figure B5. The red dots are the estimated ATT, and the 95 percent confidence bounds are in pink.

Table 2 reports the ATTs, comparing double-robust and OLS estimates. Columns 1 and 2 list the double-robust results and columns 3 and 4 list the linear TWFE results. Panels A and B present the estimates for the 5-digit and 4-digit panels, respectively. Estimates without controls are provided in columns 1 and 3, and those with controls are shown in columns 2 and 4 . The preferred specifications are doubly robust estimates with controls.

The ATT results in Table 2 reveal that the overall average impact of HCI targeting was meaningful and large. ${ }^{20}$ The preferred estimates in Panel B column 2 indicate 122.52 percent growth in output for HCI manufacturers relative to non-HCI manufacturers. Estimates for the 5-digit data (Panel A column 2) suggest 161.71 percent output growth (all significant at the 1 percent level). The doubly robust estimates for output tend to be larger than OLS estimates.

The average impact on labor productivity (Panel A column 2) translates into a 58.07 percent increase in value added per worker for HCI-targeted industries after 1973. Labor productivity growth ranges from $36.65 \%$ to $74.16 \%$ across the estimates in the 5-digit data. Productivity estimates are precisely estimated across preferred specifications and across the 4-digit and 5-digit data.

Table 2 also reveals substantial development in the heavy export industry. Before 1973, the mean RCA index for targeted sectors was .76, while the average RCA for nontargeted Korea was nearly triple that (2.28) (Appendix Table A3). The preferred estimates give an increase of 48.1 in RCA for the classic RCA index, and targeted products were 10.56 percent more likely to realize comparative advantage on the world market (Table 2, col 2). For the real value of exports, DD estimates (Poisson ML col 4.) indicate exports increased 139 percent for HCI manufacturers compared to non-HCI manufacturers. This is not out of bounds for the period. The World Bank reports for the era (Yoon-Je Cho and Kim 1995; K. Kim and Leipziger 1993) calculate that for HCI industries, the export share of output tripled during the HCI period (K. Kim and Leipziger 1993), as did the share of total manufacturing exports (Yoon-Je Cho and Kim 1995). The grand export target of the original HCI plan (50 percent of manufacturing exports) was, in fact, surpassed by 1983 (ibid).

For output prices, Table 2shows that the semiparametric estimates are systematically smaller (in absolute terms) than the OLS estimates. Nevertheless, they are strong (and significant at 1 percent, column 2), indicating that output prices were 12 percent lower following HCI (4-digit data). The 5-digit estimates also suggest 12 percent lower output prices.

The average employment effects of HCI in Table 2 are also substantial. Here, semiparametric DD estimates tend to be larger than OLS DD estimates. Panel A column 2 indicates that employment grew 74 percent more for

\footnotetext{
${ }^{20}$ The ihs-linear elasticities are calculated using $100 \times \exp (\hat{\beta}-.5 \times \widehat{\operatorname{Var}}(\beta))-1$. At sufficiently high values, ihs approximates log-linear elasticities (Bellemare and Wichman 2020; Aihounton and Henningsen 2020).
} 
HCI manufacturers after 1973 (significant at 1 percent). The 4-digit data suggests an effect of 56 (0.479 estimates with 0.273 standard error).

\subsection{Direct Impact: Cross-Country Evidence}

A) Cross-Country Variation and Triple Difference Estimation. How did the HCI experience in South Korea fare relative to the world? Cross-country data allows me to move beyond the within-country comparisons above. I use a DDD estimation strategy to expand on the DD analysis above; intuitively, I compare the original DD estimates between HCI and control manufacturers in Korea to placebo DDs across international markets. Formally, I estimate the following:

$$
\begin{array}{r}
Y_{i c t}=\alpha_{i}+\sigma_{c}+\tau_{t}+\sum_{j \neq 1972} \beta_{1 j} \cdot\left(\mathrm{HCI}_{i} \times \mathrm{Year}_{t}^{j}\right)+ \\
\sum_{j \neq 1972} \beta_{2 j} \cdot\left(\text { Korea }_{c} \times \text { Year }_{t}^{j}\right)+ \\
\sum_{j \neq 1972} \beta_{3 j} \cdot\left(\text { Korea }_{c} \times \mathrm{HCI}_{i} \times \text { Year }_{t}^{j}\right)+\epsilon_{i c t}
\end{array}
$$

where $c$ denotes country, $i$ denotes industry, and $t$ denotes time. Using cross-country industry-level data, specification (3) builds on the DD specification [eq. (1)] by adding the additional triple interaction $\mathrm{Korea}_{c} \times \mathrm{HCI}_{i} \times$ Year $^{j}$, where Korea is a dummy indicator demarcating Korea. As before, industry fixed effects are $\alpha_{i}$ and time effects are $\tau_{t}$. The term $\sigma_{\mathcal{C}}$ corresponds to country-level effects. In line with the trade literature, I use two-way standard errors, clustered at the industry and country level.

Cross-country cross-industry data allow me to include time-varying industry effects $\alpha_{i t}$ and country effects $\sigma_{c t}$, which subsume the $\mathrm{Korea}_{c} \times$ Year and $\mathrm{HCI}_{i} \times$ Year interaction in eq. (3). The coefficient of interest is $\beta_{3 j}$ estimated from the three-way interaction term $\mathrm{Korea}_{c} \times$ Year $\times \mathrm{HCI}_{i}$. In effect, I compare the conventional DD for Korea to placebo DDs sectors over the same period. The identifying assumptions of DDD estimators are distinct from DD, and do not require the two distinct pre-trend assumptions to hold. We require differences in HCI and non-HCI outcomes for Korea to have trended similarly to differences in HCI-targeted and non-HCI-targeted industries in control units (Olden and Men 2022). The difference between two biased DD estimators remains unbiased as long as the bias is similar in both.

The cross-country HCI analysis - and equation 3-addresses numerous concerns about estimating the direct impacts of IP using only industry-level variation within Korea. For example, the analysis allows for the comparison of Korean HCI-targeted industries relative to the experience of HCI-targeted industries elsewhere. By doing so, I hope to address issues related to the violation of the stable unit treatment value assumption (SUTVA). If linkage spillovers from HCI-targeted industries impact non-HCI-targeted industries, this may bias estimates using only within-Korea variation. Last, DDD allows me to address concerns as to whether Korean HCI-targeted industries would have advanced in lockstep with the global HCI sector, regardless of the intervention.

I focus on eq. (3), estimated using cross-country trade data (UN Comtrade, SITC 4-digit level). I also consider less complete, coarser sectoral data for robustness (United Nations Industrial Development Organization (UNIDO), 2-digit level). Since bilateral trade data contain many zeros, introducing concerns about heteroskedasticity (Silva and Tenreyro 2006), in line with the empirical gravity literature, I estimate eq. (3) using PPML as opposed to OLS. 
B) Results: Cross-Country Trade Development. Figure 5 presents the triple differences for the impact of Korean HCI on RCA. The panels in Figure 5 plot the coefficient from the interaction: Year $\times$ Korea $\times$ HCI. I present multiple specifications: one using individual county, year, and industry effects; one using industry-year and country effects; and one with industry-year and country-year effects.

Panel A of Figure 5 reveals, qualitatively, the same pattern across the three measures of trade development: first, a declining or minimal difference between Korean HCI-targeted industries relative to the controls; second, a reversal (improvement) of their trade performance during the HCI period; and third, an expansion of Korean HCI export performance in the periods post-1979.

Three outcomes are presented in Figure 5 indicating a post-1973 break in the development of HCI export industries. The top row of 5 provides cross-country estimates for the measure of relative export productivity (CDK). Note that CDK excludes zeros. The middle row in Figure 5 shows a similar shape and pattern for the conventional RCA measure (ihs normalized), and the bottom row reports the probability of realizing comparative advantage.

How unusual is it for a country to cultivate export advantage in HCI markets? Table C1 examines the probability of achieving comparative advantage in Korea versus control countries. I restrict products to the post-1972 period and focus on HCI products only. I regress an indicator equal to one when an HCI product has RCA > 1 as an indicator for Korea versus control countries. Because of the many zeros, I present both PPML and linear fixed effect estimates. For the period 1972-1986, the average country had comparative advantage in 7.6 percent of HCI products. Columns 1 and 5 show that Korea is significantly different in its post-1972 comparative advantage in HCI goods. In fact, the effect of Korea is stronger than the effect of log gross domestic product per capita (columns 2 and 6)(2010 real PPP adjusted).

Korea was particularly more aggressive in cultivating development in HCI than countries with similar incomes in 1972. Columns 4 and 8 show that Korea is more likely to cultivate RCA than countries in the same income deciles. This effect is even stronger if one considers South Korea relative to other countries in its decile and those above and below it in 1972 (countries one band above and one band below). OLS estimates show Korea had a significantly higher (between 9 and 14 percent higher) probability of achieving comparative advantage in HCI products over the post-1972 period, relative to comparison country HCI.

C) Robustness: Cross-Country Industry Data. Thus far we have only considered cross-country comparisons of export development. What about industrial development outcomes? Cross-country industrial (UNIDO) data are far less comprehensive and granular than trade data. Nevertheless, Appendix Figure C1 considers DDD estimates for industrial outcomes recorded at the 2-digit level. ${ }^{21}$ As before, outcome variables are ihs normalized. Appendix Figure C1 reveals a salient effect for value added (top row) and workers (middle). Labor productivity (bottom), the ratio of the two panels above, is much noisier. However, differences in HCI labor productivity narrow through the HCI period after the post-1974 bump, and this trend continues after the crisis of the 1970s. I take UNIDO estimates for robustness given the data limitations.

\subsection{Direct Impact: Discussion}

The empirical relationship between IP, HCI in particular, and industrial development is not a foregone conclusion. For a multitude of reasons, theoretical and empirical, researchers anticipate a negative relationship between IP and development outcomes. Correlation studies of IP have confirmed this (Rodriguez and Rodrik 2001; Harrison and Rodriguez-Clare 2009, 4092) (see Section 3). This section showed the positive relationship between HCI IP across industrial development outcomes, from output growth to various measures of productivity. The impact of HCI is seen throughout the HCI period (1973-1979) and these effects seem durable.

\footnotetext{
${ }^{21} \mathrm{HCI}$ sectors must be (re)coded at the 2-digit level. For this reason, the mapping to HCI industry is decidedly less refined than 4-digit and 5-digit coding.
} 
These patterns are robust across data sets (short-term and long-term panels), the type of estimator (TWFE vs. doubly robust), and importantly, when using cross-country variation. Next, I turn to the forces underlying these results.

\section{Policy and Mechanisms}

Given the direct impact of HCI on industrial development, I now turn to the roles of policy and economic mechanisms. I first consider evidence surrounding the importance of investment policy (Section 6.1) and show that evidence of output market protection for HCI-targeted industries is weak (Section 6.2). Second, I provide evidence that suggests learning-by-doing mechanisms may correspond to the direct effects determined in Section 6.3 above.

\subsection{Policy: Credit Expansion, Investment, and Input Use}

A) Responses to Investment Policy. The HCI drive sought to promote investment and inputs through directed credit and investment policy. How impactful was the change in credit and investment incentives during HCI? To address this question, I must consider the observability of this class of policy lever. In general, a major barrier to IP studies is the direct observation of policy (see Kalouptsidi (2018) for discussion), and HCI is no different. For Korea, observability is complicated by the nature of directed credit policies, which are the crux of $\mathrm{HCI}$ - policy loans were disseminated by both development-oriented banks and through the commercial banking sector (Section 2), and credit flowing to specific sectors is not recorded in industrial data. In line with the literature on credit policy in developing countries (Banerjee and Duflo 2014; Manova, Wei, and Zhang 2015), I examine indirect outcomes related to investment policy, such as those related to input costs (total materials expenditure) and investment (total fixed capital formation). Additionally, I study changes across treated industries with high versus low marginal returns to capital (Bau and Matray 2021) in treated industry.

Figure 6 presents the changes in aggregate input use by industry, revealing the widening gap for fixed (Panel A) and variable (Panel B) costs across the two types of manufacturing industries. For gross capital formation (Panel A), this wedge begins at the start of the drive and widens throughout the HCI period. Panel B shows a similar, if not more acute, divergence in total material outlays.

Turning to disaggregated data, Figure 7 presents DD estimates for investment-related outcomes, using specification 1 at the 5-digit level. Panel A of 7 shows that this divergence is starkest for materials, beginning in 1973 and widening throughout the drive. Panels B and $C$ reveal divergence in total capital stock and capital formation, respectively. Estimates for material outlays and capital stock become significantly different between the treated and nontreated industries soon after the start of HCI. The effects are starkest for baseline controls and diminish when controlling for pretreatment covariates, including pretreatment input intensity.

The average total increase in material and investment after 1973 was substantial. Table 4 lists both the doubly robust and linear DD estimates of the average effect (ATT). Preferred estimates (column 2, 5-digit panel) translate into a 134.23 percent relative increase in variable costs for $\mathrm{HCI}$ over non-HCI manufacturers. DD estimates for materials are highly significant for 5-digit data. Preferred estimates (column 2) show a total 116.64 percent increase in investment for HCI over non-HCI manufacturers during the study period. The 5-digit DD estimates in Panel A are significant, whereas the 4-digit estimates are positive but imprecise.

For robustness, Online Appendix Table 5 demonstrates that investment increased across key asset classes, specifically equipment. Column 1 shows that the results for investment are strongest for machinery and equipment, followed by building and factory-related fixed capital investment (column 3). Transport equipment also increased during the HCI drive. This is consistent with the forms of investment incentivized by lending policy. Additionally, Online Appendix Table 5 reveals that inventory investment over sales did not change, but 
rather levels of inventories changed. This is useful because the rise in inventories over oil shocks typically refer to the inventory-to-sales ratios, not levels. Increase for this ratio is in large part caused by sales responding negatively to oil shocks (Herrera 2018) (e.g. 1973). This was not the case during the early oil shocks of HCI, as sales increased for HCI sectors.

B) Mechanisms: Changes in Investment and Input Wedges. A major part of the drive, directed credit, potentially reduced the wedges on inputs for industry during the HCI drive, particularly for targeted industries. Bau and Matray (2021) note that capital market reforms that expand credit should disproportionately impact firms with high wedges, and these wedges can be captured through pretreatment marginal revenue product of capital (MRPK). Such interventions should disproportionately impact investment in high-MRPK industries and increase the marginal revenue product of other inputs.

I create a basic measure of industry-level MRPK, calculated for before HCI, using the method proposed by Bau and Matray (2021).22 I then examine the differential impact of HCI targeting on high-MRPK versus low-MRPK industries before and after the drive. My MRPK calculation is limited by industry-level data and is calculated using the most disaggregated 5-digit panel. I use total sales as a proxy for revenue divided by total tangible capital stock and estimate capital coefficients at the 2-digit level. Using these MRPK measures, I split industries into high-MRPK and low-MRPK industries, according to the median level of pre-period MRPK.

Figure D1 shows the relationship between high-MRPK versus low-MRPK industries and the increase in intermediate input use. I estimate regressions separately for HCI-targeted and non-HCI-targeted industries. Panels A (total material outlays) and B (capital formation) demonstrate that inputs increase in high-MRPK industries relative to low-MRPK industries after 1973 and only for HCI-targeted relative to non-HCI-targeted industries. Similar to materials, high-MRPK industries increase in terms of labor (Panel C) and, by virtue of increased inputs, output (Panel D). The results in Figure D1 suggest that policy differentially relaxed constraints for highMRPK industries, translating into an increase in input use. I use this as indirect evidence that credit expansion was differentially operating for HCI-targeted industries. Note that these results do not suggest that MRPK converged or that misallocation improved (both unlikely) as a result of the policy.

Thus, investment policies likely succeeded in driving investment in HCI sectors, reducing wedges for highMRPK industries, specifically among HCI producers. Beyond similarities to the directed credit literature, the expansion in credit to HCI-targeted industries during the HCI drive shares similarities with the macroeconomics literature on credit booms and instability (Mendoza and Terrones 2008; Gorton and Ordoñez 2020). Although this literature has emphasized the aggregate correlates of credit booms, those sectors receiving credit may also matter and have wider implications for the impact of credit booms in industrializing economies.

C) Robustness: Investment and Crowding Out. Was HCI deleterious for investment in non-HCI-targeted industries? I turn to this question now. I find that investment, although higher in HCI industries, did not decline for non-HCI industries.

Before testing for crowding out, it is worth considering the context. Section 2 demonstrated that, although biased toward HCI, lending continued for the non-HCI manufacturing sectors throughout the drive. Although under state control, commercial banking continued to lend to non-HCI-targeted industries, remaining a sizable and competitive swath of the economy. Figure A1 Panel A (Section 2) plotted the rise in new loans for HCI sectors, yet it also showed continued lending for non-HCI-targeted industries. The trends in non-HCI growth support this. Section 5.2 demonstrated that the relative ascent of HCI was not driven by a decline in non-HCI manufacturing but by the uptick in HCI and the continued trend of non-HCI manufacturing. Nevertheless, the cost of capital may have been higher among non-HCI-targeted industries and investment may have been crowded out through other means.

${ }^{22}$ Here, the marginal revenue product of capital for industry $i$ is $M R P K_{i}=\alpha_{i}^{k} \times\left(\right.$ Revenue $\left._{i} / K_{i}\right)$. 
Now, consider the patterns for investment across sectors during the drive. Panel A of Appendix Figure D2 presents the pattern of investment separately for each sector relative to 1972. Panel A plots the coefficients for regression investment for year effects, controlling for 5-digit-industry fixed effects. ${ }^{23}$ Investment was high in HCI-targeted relative to non-HCI-targeted industries during the period, although it generally increased across both types of industries. This is consistent with the patterns of lending and growth seen above.

What about patterns of investment in capital-intensive non-HCI-targeted industries? Perhaps investment was crowded out for capital-intensive industries. Appendix Figure D2 Panel B plots the impact of pretreatment capital intensity on investment during the HCI period as well as the coefficients from the interaction Year $\times$ asinh(Pre-Treatment Capital Intensity). Capital intensity is measured using pre-1973 capital stock divided by workers. Once again, estimates are shown separately for HCI and non-HCI samples.

Appendix Figure D2 Panel B does not show a relative decline for investment in capital-intensive nontreated sectors during the drive. The relationship between capital intensity and investment is mostly zero for $\mathrm{HCI}$ sectors and non-HCI sectors during the period. The exception is the early part of the drive, in which investment increased capital-intensive industry in both sectors. After liberalization, more capital flowed to the capitalintensive sectors. In HCI sectors, which on average tend to have substantially higher capital intensity, the relationship between capital intensity and investment is zero, even after liberalization. In addition, note that Figure D1 panel B above also showed that investment did not differentially change for high-MRPK versus low-MRPK industries during the drive.

Thus, although HCI altered the patterns of investment that would have occurred for non-HCI-targeted industries, it seems to have not led to a decline in investment. Although less striking than investment in HCI, domestic lending did continue, as light industry seemed to have access to domestic credit as well as credit from countries such as Japan (Castley 1997).

\subsection{Policy: Trade Policy and the Weak Case for Nominal Protectionism}

A) Unrivaled Protectionism? Narratives of HCI have focused on the central role of trade policy. Many have emphasized output protection and HCI has been popularly characterized as overtly protectionist (Lall 1997). Figure 6 Panels D and E show two simple measures of market protection across HCI-targeted and non-HCItargeted industries for five periods between 1968 and 1982. Panel D reports the average tariff rates (percent), and Panel E presents measures of QR coverage. ${ }^{24}$ Panels D and E demonstrate that output protection, measured in terms of tariffs and QR coverage, was lower in HCI manufacturing industry than in other industries. Figure 6 that average measures of nominal protection fell, with a slight rise in the 1970s before ebbing by 1982. Liberalization would proceed fully after 1982 (see section 2).

Drilling down, Appendix Figure D3 shows convergence in the distribution of (output) trade policy between HCI and non-HCI manufacturing industries from 1968 to 1982. The right column of D3 plots the kernel density estimates for tariffs over time, whereas the left column plots kernel density estimates of QR coverage over time. The distribution of protection policies in 1968 are widely dispersed and eventually overlap by 1982. Notably, HCI-sector trade policies do not shift toward (rightward) protectionism during the five periods.

I evaluate the case for overt nominal protection more precisely by regressing industry-level measures of (input or output) protection on the binary indicator for HCI-targeted industries. Formally,

\footnotetext{
${ }^{23}$ asinh(investment) ${ }_{i t}=\alpha_{i}+\sum_{j \neq 1972} \beta_{j} \cdot$ Year $_{t}^{j}+\epsilon_{i t}$. I thank an anonymous referee for suggesting the analysis in this section.

${ }^{24}$ Quantitative restrictions are often heterogeneous, and aggregating them into tariff equivalents is challenging. In line with a common approach in the non-tariff barrier literature, Luedde-Neurath (1986) coded the severity of quantitative restriction-mainly quotas - for products within 4-digit industries using a $0-3$ scale to indicate coverage, zero being no restrictions and three being the most severe restrictions.
} 


$$
Y_{i t}=\alpha+\beta \cdot\left(\text { Targeted }_{i}\right)+\tau_{t}+X_{i}^{\prime} \Omega+\epsilon_{i t}
$$

where $i$ are industries and $t$ are the five periods covered in by trade policy (1968, 1974, 1978, 1980, and 1982). Specification (4) controls for time period $\tau_{t}$ and includes baseline controls (average wages, material costs, plant size, and labor productivity). I estimate this relationship in terms of levels and differences: $Y$ and $\Delta Y$. The coefficient of interest, $\beta$, provides the difference in the average level—or change-in policy between HCI and nonHCI industries industries during the five periods from 1968 to 1982.

First, consider differences in the level of market protection between treated and non-treated sectors. Table 5 Panel A reports that output protection was, on average, lower for HCI-targeted industries. Columns 1 and 2 show this for average output tariffs, and columns 5 and 6, for QR coverage (significant at the 1 percent level). For completeness, column 2 reports estimates weighted by the pre-1973 value of imports. restricts the sample to only post-1973 observations, and estimates indicate that the level of tariffs for HCI-targeted industries was 25 percent lower during the HCI period.

Recall, Appendix Table A2 reveals that before HCI, levels of nominal output protection (tariffs and restrictions) were significantly lower for treated industries. Panel A, columns 9-12 of Table 5 report estimated changes in output protection between 1968 and 1982. All estimates are positive, though imprecisely estimated. The most liberal estimates suggest that, at best, tariffs increased 5 percent over the period. This is likely because they fell less for targeted than for nontargeted industries on average.

However, HCI-targeted industries were assisted by trade policy vis-a-vis exemptions on duties and tariffs for imported inputs (see section2). I consider the differential exposure to input protection using industry-level measures of input protection built from IO tables (see Section 4). These measures of input tariff exposure account for the potential exemptions afforded to HCI-targeted industries during the period.

Table 5 Panel B reports estimates for input exposure outcomes, with columns 9-12 reporting estimates for changes in exposure to input protection. Column 10 suggests that HCI manufacturers enjoyed a 5 percent reduction in import tariffs as a result of the HCI drive import exemptions. Estimates for reductions in QRs, although negative, are insignificant.

\subsection{Mechanisms: Targeted Industry and Learning Mechanisms}

A) Testing for Dynamic Scale Economies. I now turn to potential learning-by-doing mechanisms underlying this development. Likewise, extensive literature on the East Asian miracle has examined the extent to which targeting corresponded to such spillovers, a key impetus for IP (Beason and Weinstein 1996; Pons-Benaiges 2017). I explore these forces in line with the learning-related literature, particularly the endogenous specifications used by Bahk and Gort (1993), Thornton and Thompson (2001), Thompson (2001), Fernandes and Isgut (2005), and Pons-Benaiges (2017). I use this analysis to explore whether learning forces were present in treated industries during (and after) the HCI period and the extent to which they differed between HCI and non-HCI manufacturers.

If learning-by-doing forces were at work in treated sectors, cumulative experience of industry (or firms) would be related to an increase in productivity or a decrease in unit cost. If HCI-targeted industries were prone to these externalities, they should exhibit high rates of learning, including industry-wide learning spillovers as opposed to plant-level spillovers. I draw from the literature on learning (Thompson 2010) and estimate the following reduced-form equation,

$$
Y_{i t}=\beta_{1} \text { Experience }_{i t}+\beta_{2}\left(\text { Experience }_{i t} \times \text { Targeted }\right)+\theta \text { Size }_{i t}+\alpha_{i}+\tau_{t}+X_{i t}^{\prime} \Omega+\epsilon_{i t}
$$


where $Y_{i t}$ is industry (firm) TFP, or alternatively, prices or labor productivity, in accordance with Barrios and Strobl (2004) and Fernandes and Isgut (2005). ${ }^{25}$ I study the post-1972 policy period. Equation (5) seeks to understand the relationship between industrial outcomes and Experience ${ }_{i t}$ which is measured as the cumulative quantity of output, or more precisely, the per-period cumulative quantity of output per worker. Following the literature, cumulative output is normalized by the number of workers to adjust for conventional scale effects (e.g. Bahk and Gort 1993). Similarly, the baseline specification controls for static scale effects Size $i t$. Moreover, since technological progress may be embodied in capital goods or inputs, I additionally control for per worker intermediates, $X_{i t}^{\prime} \Omega$. Equation (5) also includes industry (firm) effects and period effects.

Equation (5) is correlational and conveys the scope of dynamic learning externalities across HCI-targeted versus non-HCI-targeted industries after the policy announcement. Coefficient $\beta_{1}$ is the general impact of cumulative output (Experience ${ }_{i t}$ ), while coefficient $\beta_{2}$, is the differential impact of Experience ${ }_{i t}$ for HCI industry during the planning period. Estimates from eq. (5) test whether the scope of dynamic externalities is prominent in targeted industries, in the spirit of Beason and Weinstein (1996) and Pons-Benaiges (2017). These results are not causal; see Thompson (2010) for sources of bias in learning regressions.

B) Results: Learning Mechanisms in Industry-Level Data. Productivity increased with cumulative output in treated sectors during the HCI period, and these learning dynamics were more prominent in the treated sectors. First, panel A, Table 6 gives estimates of Experience within the sample of HCI-only manufacturing industry, where experience is positive and significantly related to measures of productivity, such as TFP (OP columns 5 and 6 and ACF columns 7 and 8) or value added per worker (columns 3 and 4), and experience is strongly related to reductions in prices (columns 1 and 2).

I now consider differential learning between HCI and non-HCI industry, Panel B in Table 6 reveals that learning stronger in targeted industries than in nontargeted industries. Considering all 5-digit manufacturing sectors, panel B shows that learning forces are relatively stronger in treated industries. All estimates of $\mathrm{HCI} \times \mathrm{Learning}$ are significant. Importantly, the total joint effect of learning $\left(\beta_{1}\right.$ Learning $+\beta_{2} \mathrm{HCI} \times$ Learning), given in the bottom of Table 6, is strong and significant.

Export experience is also positively related to comparative advantage in HCI-targeted industries. By merging RCA measures with long 4-digit industry-level panels, Table 6 shows a strong relationship between cumulative export experience and RCA. Since capital stocks are not available for 4-level data, investment per worker is used as a control. The differential effect of experience is positive and insignificant for CDK-based RCA measures and is significantly related to the conventional (ihs) RCA measure.

C) Results: Decomposing Firm versus Industry Learning in Post-HCI Microdata. Does industry-level experience benefit firms operating within an industry? I address this question using plant-level panel data, which are only available for the periods after 1979. Moving beyond industry-level data, I consider correlational evidence of both plant-level learning for HCI factories and industry-level spillovers within HCI-targeted industries.

Table 7 presents the learning effects, estimated by regressing TFP on measures of plant-level and industry-level experience, for the post-HCI period. Across all specifications, the relationship between plant-level cumulative experience $(\mathrm{HCI} \times$ Experience) and TFP $(\mathrm{ACF})$ is significantly higher for plants operating in HCI markets versus non-HCI markets. Columns 2-5 adds industry-level measures of experience and the differential effect of industry-level experience in HCI markets (HCI $\times$ Experience [Industry]). In these regressions, industrylevel learning effects are stronger for HCI plants, and the differential effect is larger (and significant) for industry-level learning among HCI plants.

${ }^{25}$ Experiencing increasing labor productivity is the same as experiencing decreasing unit labor costs. In addition, prices are only a rough proxy for learning activity in a noncompetitive market and are also a function of other demand parameters (Gruber 1998). 
Of course, the combined effect of plant-level learning is more consequential for TFP than for industrylevel learning, as demonstrated by the combined coefficients at the bottom of Table 7. From TFP in Table 7, industry-level learning spillovers are more than a third of the firm-level spill-overs using ACF measures of TFP. Appendix Table D1 shows estimates across five alternative measures of TFP, where industry-level spillovers are significant and meaningful across most TFP measures (except OLS), with a slightly larger effect for the alternative measures of TFP.

Together, these results indicate that industry-level learning externalities- - an argument for infant-industry policy-_seem plausible for HCI-targeted industries in plant-level data in the post-HCI period. However, these results are cursory and correlational. Additionally, for the microdata estimates above, I only observe plant-level and industry-level experience for the period after 1979, given limited panel data. Likewise, I cannot control for plant age. Nevertheless, the microdata provide evidence compatible with the longer-term industry estimates. Taken together, the results in this section hint at plausible learning-by-doing mechanisms, such as those described in 5.

D) Policy Horse-Race. How did changes in policy-related variables, or experience, contribute to growth in the HCI sectors? Appendix Table D2 shows estimates from the following equation for a sample of HCI industries,

$$
\Delta Y_{i t}=\beta_{1} \Delta \text { OutputProtection }_{i t}+\beta_{2} \Delta \text { InputProtection }_{i t}+\beta_{3} \Delta \text { Investment }_{i t}+\beta_{4} \Delta \text { Experience }_{i t}+\tau_{t}+\epsilon_{i t}
$$

where annualized growth outcomes, $Y$, are regressed on the growth of policy variables for the periods 1968, $1974,1978,1980,1982$, the periods in which trade policy data is available. ${ }^{26}$ The baseline specification (6) includes period effects $\tau_{t}$. These data are only available for the 4-digit industry panel, and thus they are run for a small sample (33) of industries. Nevertheless, the point is to convey their contribution to growth.

Table D2 demonstrates that changes in investment are correlated with strong changes in output (value added) (columns 1-3) and employment (columns 4-6). Although investment is positively related to both outcomes, it is not positively correlated with value added per worker (columns 7-9). Cumulative industry experience (learning-by-doing type) for specification s(columns 3,6, and 9) is most positively correlated with all output measures, though is harder to interpret in this setting (without further controls).

Cuts in intermediate input tariffs are associated with growth. For instance, column 3 shows that, after controlling for experience effects, input cuts and investment growth have the same correlation with annual growth in value added (absolute value of approximately .44). Moreover, growth output protection for tariffs is strongly negatively correlated with industry growth in Table D2, whereas QR output protection is positive but imprecisely estimated. Thus, output cuts, investment, and, in particular, learning-by-doing-type forces are most strongly associated with growth during the 1968-1982 period. The latter should, however, be interpreted with caution.

\section{$7 \quad$ Indirect Impact of Industrial Policy}

I now consider how HCI may have impacted manufacturing industry outside of targeted sectors. The network in Figure E2 visualizes linkages for the Korean economy using data from the 1970 South Korea input-output accounts. Red nodes are targeted industries. Gray nodes are nontargeted industries. The size of nodes reflect the total number of connections, or "degrees". ${ }^{27}$ I use the terms "backward" and "forward" from the vantage point

\footnotetext{
${ }^{26}$ In line with the growth literature, $\Delta y_{i t}$ is equivalent to $\ln \left(y_{i t} / y_{i t-k}\right) \cdot(1 /[t-(t-k)])$ where periods $t$ and $t-k$ are two periods.

${ }^{27}$ For clarity Figure E2 plots "medium" $153 \times 153$ input-output accounts. "Treated" HCI nodes in Figures E2 differ slightly from those used in the industrial census data set as input-output data is presented at a different level of aggregation and using a different coding nomenclature. The figure uses the Kamada-Kawai (1989) algorithm for spacing nodes.
} 
of a targeted industry. The connections in E2 indicate a link between two industries; specifically, nodes are connected if an industry sells its output to another downstream industry. Industries with more links appear closer to one another.

A) Measuring Linkage Exposure to HCI. To study the impact of IP through linkages, I construct measures of network exposure to HCI targeting using digitized 1970 ("basic") IO accounts for South Korea. I use the 1970 IO tables, as they predate the HCI drive and limit the extent to which linkages are endogenously formed under the drive.

Consider two industries, where $i$ is a nontargeted industry and $j$ is a treated industry. The nontreated industry is backward linked if it supplies its output to a treated industry. This direct relationship is denoted $i j$, and industries have many such links. For example, the sum of backward linkages is equal to the weighted sum of linkages between a producer and those using their output. I measure this as

$$
\text { Backward Linkages }_{i}=\sum_{j} \alpha_{i j} \quad \text { with } \alpha_{i j}=\frac{\text { Sales }_{i j}}{\sum_{j^{\prime}} \text { Sales }_{i j^{\prime}}} \text {. }
$$

where weight $\alpha_{i j}$ is the value of $i$ 's sales to $j$, divided by the total sales from $i$ to all industries $j^{\prime} .{ }^{28}$ The denominator of eq. 7 is the sum of industry $i$ 's sales to all sectors. These include sales to tradable and service buyers, as well as those sold as final products.

I measure policy exposure by summing up the share of sales ( $\alpha_{i j}$ in eq. 7$)$ to targeted industries only:

$$
\text { Backward HCI Linkages }_{i}=\sum_{j \in \mathrm{HCI}} \alpha_{i j} \text {. }
$$

In other words, (8) measures only linkages between $i$ and targeted buyers $j \in \mathrm{HCI}$, where HCI is the set of targeted industries. The forward linkage analog of 8 are calculated in the same way, but flipped. For forward links, Forward Linkages $_{i}$ is equal to $\sum_{j} \alpha_{j i}$, and Forward HCI Linkages ${ }_{i}$ is equal to $\sum_{j \in \mathrm{HCI}} \alpha_{j i}$.

Equation 8 captures only direct (first degree) connections that propagate between HCI industries and others. Nevertheless, total (n-degree) backward linkage measures are calculated using a method similar to that of the direct effects above but now using coefficients from the Leontief matrix (see Technical Appendix). Thus, the total linkages are calculated by

$$
\text { Total Backward HCI Linkage }{ }_{i}=\sum_{j \in \mathrm{HCI}} \ell_{i j} \text {. }
$$

where eq. 9 adds industry $i$ 's Leontief coefficients for purchasing sectors, $j$, but only for those targeted by the HCI drive. ${ }^{29}$ In other words, for an industry row $i$, I add column-wise entries $j$ for $j$ 's in the set of targeted industries. Thus, Total Backward HCI Linkage ${ }_{i}$ in equation 8 captures the total exposure of industry $i$ through all direct and indirect linkages. The Total Forward HCI Linkage ${ }_{i}$ measure is calculated in a similar way but with reversed indices. Instead of summing across columns for each row, I sum across rows $j$, for each column $i$.

\footnotetext{
${ }^{28}$ I do not count $i$ 's sales to itself and exclude diagonals $\alpha_{i i}$ in the input-output matrix.

${ }^{29}$ See the Technical Appendix (Online Appendix) for derivation of the Leontief inverse. As with the direct linkages, I do not count on-diagonal coefficients.
} 
Figure E1 lists the nontargeted sectors with the highest direct connections to the targeted sectors, measured by Backward HCI Linkages ${ }_{i}$ and Forward HCI Linkages ${ }_{i}$, eq. (8). ${ }^{30}$ On the left of Figure E1, the top 20 (5-digit) manufacturing industries with the highest share of inputs sourced from targeted sectors are presented. These sectors include Jewelry $\mathcal{E}$ related articles and Plastic products. Many of these sectors tend to be more downstream industries. On the right of Figure E1, the top 20 industries with the highest (direct) backward linkages to the targeted sectors are listed. These nontreated industries supply a large share of output with the HCI-targeted industries. Unsurprisingly, many sectors supplying a large share of output with HCI-targeted industries are relatively upstream, closer to the raw materials end of the supply chain.

B) Empirical Strategy. I use the linkage measures above to estimate the impact of HCI IP on industries downstream and upstream from the treated industries. I do so using a dynamic DD analysis in the spirit of specification (1) above (Section 5.1). Intuitively, I estimate the linkage effects of HCI by comparing outcomes across sectors with strong versus weak linkages relative to 1972. I consider the following specification,

$$
\begin{array}{r}
Y_{i t}=\alpha_{i}+\tau_{t}+\sum_{j \neq 1972} \gamma_{j} \cdot\left(\text { Backward Linkage }_{i} \times \text { Year }_{t}^{j}\right)+ \\
\sum_{j \neq 1972} \delta_{j} \cdot\left(\text { Forward Linkage }_{i} \times \text { Year }_{t}^{j}\right)+\sum_{j \neq 1972} X_{i}^{\prime} \times \text { Year }_{t}^{j} \Omega_{j}+\epsilon_{i t}
\end{array}
$$

where $Y$ is an outcome, $i$ indexes each 5-digit (or 4-digit) industry. Subscript $t$ denotes the years, which are 1967 - 1986 for the 4-digit panel and 1970 - 1986 for the 5-digit panel. The equation above now includes the time-varying impact of (ihs) share of backward links and (ihs) share of forward linkages described directly above. The baseline equation (10) is a linear TWFE specification. Fixed effects and controls are the same as the baseline DD model (1) from section 5.

The coefficients of interest in (10) convey the dynamic impact of linkage exposure on upstream and downstream industries, both of which appear in the equation. The first set of coefficients, $\gamma_{j}$, is the impact of HCI policy through backward links. The second set, $\delta_{j}$, is the impact of HCI policy through forward links. Thus, the set of estimates, $\gamma_{j} \mathrm{~s}\left(\delta_{j} \mathrm{~s}\right)$, conveys the differential development of sectors with strong backward (forward) linkages with HCI-targeted industries relative to those with weaker linkages.

Before 1972, the set of coefficients should be zero, reflecting no prior differences between industries with stronger or weaker linkages. If linkage effects are present, estimates after 1972 should increase until at least 1979 , the end of the policy. Estimates for the post-HCI period can indicate longer-term impacts of policy if coefficients continue to be greater than or equal to earlier estimates, or if coefficients diminish, they can indicate temporary policy effects. I take the 1970 network as fixed and determined prior to the episode. The identifying assumption is that differences in industrial development between stronger or weaker backward (forward) linked industries would have evolved similarly in the absence of the HCI policy.

Note that the dynamic DD specification (10) uses a continuous treatment variable, whereas DD estimates in the first part of this paper (Section 5) used a binary treatment. The continuous treatment precludes the semiparametric DD methods used in for direct policy estimates, and the results below come from TWFE estimators.

\subsection{Network Results}

For clarity, I present results separately for forward and backward linkages. I first demonstrates that industries with relatively strong forward linkages to HCI-targeted industries-downstream users dependent on targeted inputs-developed more during the HCI period. Additionally, I provide evidence that downstream sectors had

${ }^{30}$ Names of the sectors reflect both the harmonization of industry names over time and the matching of IO tables to 5 -digit industry codes. The industries are meant to convey a general qualitative pattern to the reader. 
a relatively high comparative advantage for the periods after HCI. Second, I turn to backward linkages, and show limited, even negative, impacts of HCI on industries upstream from HCI-targeted industries.

\subsubsection{Network Results: Forward Linkages and Downstream Industry}

A) Downstream Industrial Expansion. Figure 8 shows the relationship between forward linkage strength and downstream output, plotting DD estimates from equation (10). I focus on value added measures of output, given the emphasis on stages of production and linkages. Estimates using gross output tend to be stronger and the patterns are similar. Rows in Figure 8 correspond to estimates for real value added (top) and output prices (bottom).

The columns in Figure 8 give estimates by data set (4-digit vs. 5-digit) and by sample (full sample vs. non-HCI only). Figure 8 Panels B and D restrict the sample to non-HCI-targeted industries only. This restriction, however, significantly reduces the sample size and therefore power, especially in aggregate 4-digit data. Alternatively, Panels A and C give estimates using the full sample of industries, controlling flexibly for HCI-targeted industries over time. These "Entire Sample" estimates include an additional control for the interaction Targeted $\times$ Year.

The estimates in Figure 8 shows that industries with stronger forward linkages (to HCI-targeted industries) expanded their value added more during the drive. Before 1973, the differences between HCI-reliant industries were noisy, trending upwards in the 1960s but centered around zero. Online Appendix Table 7 provides the complete tables for these plots, with joint tests for pre-trends. The tests reject pre-trends across all specifications except those for the non-HCI sample in the 4-digit data; forward-linked sectors had relatively high output in the 1960s, but this gap closed and became insignificant before 1973.

Table 8 reports the average pre-post version of eq. (10). Forward linkage estimates are given alongside backward linkage estimates. For value added, average forward linkages estimates (panel A col. 2) imply a 1 unit rise in the share of links to HCI translates into 5.821 percent more output (1.957 percent in 4-digit data), with estimates significant at the 5 percent level. Five-digit estimates in panel A are all positive and more precisely estimated.

Similarly, Table F1 reports pre-post estimates for total (Leontief) forward linkages, those accounting for n-degree linkages between downstream industries and HCI suppliers. Similar to the direct linkages above, Table F1 reports a robust relationship between total forward linkage exposure and the change in downstream value added. These total effects are strongest in the non-HCI sample. The point estimates (Panel A column 4) suggest that a one unit rise in total forward linkage strength is associated with 4.954 percent higher value added after 1973 (significant at 10 percent level). ${ }^{31}$

The bottom row of Figure 8 demonstrates that industries using more HCI inputs had relatively low output prices during and after the drive, although with pre-trends. Before-1973, prices were relatively high in forwardlinked sectors, but they declined after 1973. This drop is shown across panels and samples. After 1979, this divergence slowed, although prices remained relatively low for sectors with stronger forward linkages. The complete tables shown in Online Appendix Table 8 demonstrate that pre-1973 prices were relatively high for sectors with strong forward linkages, but estimates suggest they may have been trending downward prior to the policy. TThus, although the price effects in Figure 8 are strong, these differential trends may have already been in motion. However, if trends were in motion, it is notable that IP did not break them or raise prices.

Table 9 demonstrates that the total average pre-post impact of forward linkages on output prices was significant. Estimates in column 2 (Panel A) indicate that a one unit rise in the share of total HCI linkages is associated

\footnotetext{
${ }^{31}$ Leontief coefficients are different than direct coefficients, the latter of which are interpretable as the percent share of inputs between 0-100.
} 
with 0.196 percent lower output prices in forward-linked industry. Similarly, Table F2, the relationship between total forward linkages and prices is negative across specifications.

Beyond value added and prices, I observe more entry into and higher employment in downstream sectors with stronger connections, although weak effects for productivity can be identified. Table F3 shows the average forward linkage impacts, Appendix Figure F1 shows the dynamic estimates. For brevity, I summarize the average DD estimates. Table F3 shows the effects are positive and significant for employment (columns 1-2) and number of plants (3-4). Although positive for labor productivity (5-6) and average wages (9-10), the effects are noisy. Estimates for TFP (columns 7-8) are weakest and essentially zero. Table F4 sshows the corresponding total (Leontief) forward linkage estimates, which are also positive where the relationship between TFP and total linkages is stronger (Table F4, columns 7-8).

B) Downstream Comparative Advantage. Turning to SITC-level trade data, Figure 9 shows improved export performance in downstream industries, which emerged during the HCI drive and continued to flourish after the drive. Pre-1973, forward-linked sectors did not demonstrate a higher RCA than other downstream sectors. If anything, the relative RCA trended downwards. Post-1973, the pattern shifted; for the 1973-1979 period and into the 1980s, estimates for export performance become larger and significant.

Online Appendix Table 9 shows the full tables for Figure 9. For robustness, Online Appendix Table 9 demonstrates that these patterns hold, additionally, for the probability of comparative advantage (RCA > 1) and positively (but imprecisely) when using the raw total value of exports across SITC industries. The total forward linkages (Online Appendix Table 9, Panel B) reveal a slightly stronger relationship between the strength of forward linkages and export development outcomes.

For robustness, Online Appendix Table 10 presents estimates using later domestic linkage measures from the 1975 IO tables. The core specifications used measures from the general 1970 IO tables, which did not yet distinguish between domestic and imported flows. The emergence of comparative advantage among users of $\mathrm{HCI}$ products is even stronger when we consider only domestic linkages.

The positive evolution of downstream exporters, presented in this section, is important for two reasons. First, it suggests that HCI may not only have promoted long-term development in directly targeted sectors but may also be correlated with positive effects in external markets. Although some external benefits of policy are contemporaneous, other external benefits may take time to come to fruition. Second, the results substantiate the direct effects identified in Section 5. Had HCI been unsuccessful in directly targeted sectors, it is likely that it would have harmed downstream exporters—-those sensitive to the competitive international market (Blonigen 2016).

C) Forward-Linkages: Mechanisms, Investment, and HCI Intermediates. If HCI policy impacted downstream industries, it likely did so through inputs—supplying domestic inputs for the benefit of downstream users. Figure 10 examines input use and investment in industry more or less exposure to HCI suppliers. Pre-1973, differences in total material outlays and investment were converging between sectors sectors with differential forward links to HCI suppliers. Post-1973, the trend reversed; Figure 10 shows a jump in material outlays (top row) and total investment (bottom row). The post-1973 divergence is seen in the data of both panels (A-B and C-D). Likewise, these estimates are strong when restricting estimates to only non-HCI-targeted industries.

Online Appendix Table 11 reports the full set of regression coefficients and joint F-tests. Nearly all the tests reject pre-trends with the exception of 4-digit panels, in which inputs trended upward and then converged before 1973. If targeted HCI products were useful for downstream industries, the cumulative impact of HCI inputs ought to be similarly useful. Online Appendix Table 12 presents estimates using total forward linkages. Es- 
timates for total forward linkages in the Online Appendix indicate a positive impact for total forward linkages, although noisier.

Thus, during the HCI period, downstream users of HCI inputs expanded outlays and inputs during the drive. Industries with higher HCI exposure (through forward linkages) increased their intermediate material use and investment.

\subsubsection{Network Results: Backward Linkages and Impact on Upstream Industry}

Since at least Hirschman (1958), proponents of IP have emphasized that policy can promote spillovers through backward linkages - the expansion of a targeted sector can promote upstream industries through increased demand. In the case of HCI, spillovers from HCI to upstream suppliers may have been limited. This results from the use of imported sectors. However, more fundamentally, because HCI planners (Section 2 part B) chose more upstream industries (confirmed by Liu (2019) in his analysis using the IO data from this study), backward linkage effects may have been limited.

Figure G1 and G2 illustrate the ambiguous or negative impact of HCI on upstream industry development. Similar to the forward linkages results in the previous section, Figure G1 shows the impact of direct backward linkages-upstream sectors supplying inputs to HCI industry. Before 1973, G1 shows upstream industries with stronger links were already in decline relative to those with weaker links. The complete tables (Online Appendix Table 13) demonstrate that these backward linkages were significantly different and trending downward in the pre-HCI period. After 1973, this downward trend among backward-linked sectors was not reversed by the expansion of HCI-targeted industries; Figure G1 shows noisy effects of direct backward linkages. Figure G2 (Online Appendix Table 14) shows the total linkage effects, which are more ambiguous than direct effects and are weakly negative across 4-digit panels and weakly positive in the 5-digit data.

Table 8 reports the average pre-post impact of (direct) backward linkages on output. Table F1 reports similar estimates for total (Leontief) backward linkages. In general, coefficients for backward estimates are smaller than forward effects (except for the non-HCI 4-digit sample, where they are larger), and average estimates (Table 8) are weakly negative and imprecise. Total linkage estimates (Table F1) tend toward zero, suggesting the direct effects are strongest.

One reason for the negative backward linkage effect may be that HCI expanded the use of imported inputs among HCI producers, thus subjecting upstream sectors to competition. If this were the case, we should observe a rise in imported goods used in HCI production.

Figure G3 plots the same regression as Figure G1, but now with the value of imports as our outcome of interest. The left of G3 shows estimates for direct linkages and the right shows estimates for total Leontief linkages. The estimates in Figure G3 show an increase in imports used more intensively by HCI industry. These estimates reveal an increase in imports, which were used more intensively by HCI-targeted industries. Substantively, these DD estimates indicate a relative rise in imports with higher backward linkages to HCI producers. This pattern is compatible with import competition, by virtue of HCI policy, having limited the extent to which HCI policy conferred beneficial demand spillovers to upstream industries.

\subsection{Robustness and Stable Unit Treatment Value Assumption}

The indirect effects of HCI shown above (Section 7.1) present a dilemma in light of the direct effects highlighted in Section 5.1. To estimate the direct effects of the policy, I compared the treated and control groups. However, the network effects of the policy may contaminate the control group by virtue of the linkage effects, violating the SUTVA in causal inference. I demonstrate that direct effects largely survive after accounting for the most salient network effects of the policy. 
A) Main Effects, Restricting Estimates to Low-Linkage Control Industries. For both downstream and upstream linkages, I classify non-HCI industries into two categories: low or high-linkage, based on whether they are above or below the medium the median intensity of linkages to treated HCI neighbors. I focus on direct linkages, which are of first-order importance.

Figure H1 shows baseline TWFE event study estimates (eq. (1)) of the impact of HCI on output and labor productivity alongside estimates in which I restrict the control to industries with low downstream linkages (triangles) or low upstream linkages (squares). For both output and labor productivity, estimates using a "low downstream linkage" control group increase slightly in industry panels, and the core pattern is preserved. Intuitively, it would make sense that the main effects of $\mathrm{HCI}$ increase when removing the control industries most likely to benefit from the policy spillovers. Standard errors also increase by virtue of the smaller sample.

Similarly, across outcomes, Figure H1 shows that limiting control industries to those with low upstream connections has a menial impact on point estimates for the main, direct impact of HCI (e.g. HCI $\times$ Year). This is expected, as the upstream linkage effects of policy were muted and weaker than the downstream effects (Section 7.1.2). In total, limiting the impact of the strongest first-order linkage effects on the control group is not sufficient to overcome the main direct impact of HCI.

B) Main Effects, Controlling for Linkages. Do the main direct effects of targeting survive the inclusion of forward or backward linkages? I test this by exploring whether the main TWFE event study estimates survive when including these effects, rerunning the main regression equation (1), now saturated with linkage effects. Specifically, I control for linkage spillovers for nontreated industries only. Thus, the regressions include the linkage effects calculated above, limited to nontreated industries. ${ }^{32}$

Panels A, Figure H2 shows baseline effects results for the main effect, HCI $\times$ Year versus estimates that include downstream linkage controls and the positive linkage spillovers shown above. These results are revealed for both direct linkages (left) and total Leontief linkages (right). The baseline estimates are in red, and those controlling for linkages are in dark gray. I control for linkages using the interaction Forward Linkage $\times$ Post, which controls for the linkages more parsimoniously. Controlling for the "fully flexible" linkages Forward or Backward Linkage $\times$ Year significantly increases the number of parameters. I include time-trend interactions, alternatively, in the online appendix, which are similar to the post interactions in Figure H2.

Estimates in Panel A of Figure H2 show that once we control for the positive downstream spillovers in nontreated industries, estimates for the main direct effect HCI $\times$ Year become larger. This is most prominent for linkages controlling for the total linkage effects. This is intuitive, as positive spillovers mean that the control group may also benefit the control group and bias estimates downward. However, I have demonstrated above that there may have been weak negative spillovers into backward-linked industries.

Accordingly, Panel B (Figure H2) also compares the main baseline estimates alongside the results of those controlling for linkages. However, I now include both the upstream and downstream linkages. Figure H2 shows that including both linkages maintains the main pattern while slightly increasing the standard errors. The main effect estimates are now less positive than those in Panel A because including backward linkages means we now control for the negative upstream spillovers. These spillovers are particularly strong for the direct backward linkage estimates. In both Panels A and B, the main pattern is preserved, although slightly increased (along with standard errors), once we control for the most prominent linkage effects.

C) Investment Crowding Out and Linkages. The crowding out of investment is another way in which the SUTVA assumption is violated. Section 6.1 demonstrated that investment, although higher in HCI-targeted

${ }^{32}$ E.g. Linkages are multiplied by an indicator equal to one for non-treated industry (zero for treated). 
industries, was not diminishing in non-HCI sectors, nor was this the case in capital-intensive non-HCI sectors. I now consider whether crowding out may occur after controlling for linkage intensity.

Figure H3 shows the relationship between investment and capital intensity (pre-1973 capital stock divided by employment) controlling for linkages. Estimates are shown separately for HCI and non-HCI industry samples. The left panel shows those with controls for linkages using Forward or Backward Linkage $\times$ Post, and the right panel shows those using the more intensive Forward or Backward Linkage $\times$ Year control.

After controlling for linkages, I am unable to identify a negative relationship between measures of capital intensity and investment. Broadly, the relationship between capital intensity and investment in nontreated sectors is similar to the robustness estimates that did not account for linkages in Figure D2. The relationship between capital intensity and investment-now controlling for linkages--is similar in both industries during the drive. There is a positive relationship between capital intensity and investment after 1973 for both types of industries, although the relationship is zero during the HCI period. After capital market liberalization, the relationship becomes more pronounced in both industries, with a stronger relationship among nontreated industries.

\subsection{Networks: Discussion}

Above, I provide some evidence for linkage effects associated with HCI. Where such spillovers are detectable, they appear as forward linkages. Forward linkages-spillovers from targeted industry to downstream users of HCI products - had larger impacts than backward linkages—spillovers from targeted industry to suppliers of inputs to HCI production. I demonstrated that these downstream users expanded outlays and outputs. Moreover, those with stronger forward linkages increased their use of inputs, such as steel, and investment in intermediate capital goods targeted by HCI, such as machinery. However, the impact of backward linkages may have been limited because HCI sectors were already upstream and upstream suppliers were subjected to import competition. Section 7.2 showed these linkage effects-particularly during the HCI period-may not have been strong enough so as to erase the main direct effects of the policy. The relative importance of forward linkages coincides with the study by Liu (2019), whose theoretical and quantitative research (using data from this study) reveals that optimal targeting of IP in the network may correspond to influential upstream sectors.

\section{Conclusion}

This paper shows that Korea's Heavy and Chemical Industry drive promoted industrial development in the manufacturing sectors targeted by the policy. I find that this intervention had wide ramifications. First, the drive created positive effects in treated industries long after the major elements of the policy had been retrenched. In the case of export performance, policy effects took time and fully materialized after the policy had ended. I provide cursory evidence that the dynamic effects may correspond to learning mechanisms. Moreover, the regime's policy likely impacted the development of industries not targeted by the policy, both in the short and long term.

The role of IP in the East Asian growth miracle has long been debated by economists (Amsden 1992; Chang 1993; Rodrik 1995a; Krueger 1995; Noland and Pack 2003) and among social scientists more broadly (Wade 1990; Evans 1992). This study provides some of the first estimates on the impact of infant industry policy on industrial development in this context, using newly assembled data for Korea's miracle period. By doing so, I add to a nascent literature using historical natural experiments to understand the foundations of industrial development and the role of interventions (Juhasz 2018; Hanlon 2020; Giorcelli 2019; Mitrunen 2019).

This study takes a multidimensional view of industrial development, demonstrating that HCI targeting corresponded to improvement across an array of outcomes, from export performance to labor market outcomes. In terms of real output, HCI corresponded to the doubling of output in targeted manufacturing industries rela- 
tive to nontargeted industries. I argue that Korea's IP relied on investment incentives and the availability of imported intermediates rather than the overt protection of output markets.

My findings correspond with some arguments posed by Wade (1990) and Amsden (1992), mainly that active policy contributed to Korea's industrialization and its shift in comparative advantage to more advanced industries. The results in this study, however, emphasize conventional economic mechanisms and forces. These include the use of directed credit to facilitate investment, the purchase of key intermediates, and the promotion of sectors with dynamic economies and linkage spillovers.

Of course, history is not a clean laboratory, and South Korea's IP experience is no exception. Nevertheless, this study attempts to discipline a key episode of IP using the contemporary econometric toolbox. The goal is to structure coherent insights around a key historical case of industrial transformation. By doing so, I hope to extract the coherent workings of the policy-those that are useful more broadly-and emphasize a more empirically grounded narrative around East Asian interventions.

A key point of this study is to document more precisely "what happened." I do so in light of the controversies surrounding IP practice (Lane 2020), East Asia (Wade 1990; Pack 2000), and HCI in Korea (Yoo 1990). Moreover, although the HCI policy perhaps led to industrial development, it did so with costs. The multitude of costs are not accounted for, and cannot be accounted for, within this study. Similarly, this study cannot speak to whether a more efficient set of sectors may have existed. Although my study highlights the impacts of IP on industrial development outcomes, I have not examined the aggregate or allocative consequences of policy. Importantly, the context of this study suggests that successful IP likely hinges on bureaucratic capacity (Johnson 1982; Evans 1995; Fukuyama 2014) and political incentive compatibility (Haggard 1990; Chibber 2002; Robinson 2010; Vu 2010). Such conditions may be rarely satisfied (Krueger 1990), highlighting the importance of future research on the political economy of IP. 


\section{References}

A. Smith, Jeffrey, and Petra E. Todd. 2005. "Does matching overcome LaLonde's critique of nonexperimental estimators?" Journal of Econometrics, Journal of econometrics, 125 (1-2): 305-53. https:/ /doi.org/DOI: ,

Acemoglu, Daron, David Autor, David Dorn, Gordon H Hanson, and Brendan Price. 2015. "Import Competition and the Great US Employment Sag of the 2000s." Journal of Labor Economics 34 (S1): S141-98.

Ackerberg, Daniel A, Kevin Caves, and Garth Frazer. 2015. "Identification Properties of Recent Production Function Estimators." Econometrica 83 (6): 2411-51. https://doi.org/10.3982/ECTA13408.

Aghion, Philippe, Jing Cai, Mathias Dewatripont, Luosha Du, Ann Harrison, and Patrick Legros. 2015. “Industrial policy and competition." American Economic Journal: Macroeconomics. https://doi.org/10.1257/mac.20120103.

Aihounton, Ghislain B D, and Arne Henningsen. 2020. "Units of measurement and the inverse hyperbolic sine transformation." The Econometrics Journal, October. https://doi.org/10.1093/ectj/utaa032.

Amiti, Mary, and Jozef Konings. 2007. “Trade Liberalization, Intermediate Inputs, and Productivity: Evidence from Indonesia." American Economic Review 97 (5): 1611-38.

Amsden, AH. 1992. Asia's Next Giant: South Korea and Late Industrialization. Second. New York, New York: Oxford University Press.

Bahk, Byong-Hyong, and Michael Gort. 1993. “Decomposing Learning by Doing in New Plants.” Journal of Political Economy 101 (4): 561-83.

Balassa, Bela. 1965. "Trade Liberalisation and "Revealed" Comparative Advantage1." The Manchester School 33 (2): 99-123. https://doi.org/10.1111/j.1467-9957.1965.tb00050.x.

Baldwin, Richard, and Paul Krugman. 1988. "Market Access and International Competition: A Simulation Study of 16K Random Access Memories." In Empirical Methods for International Trade, edited by Robert Feenstra, 1st ed., 171-97. Cambridge, MA: MIT Press.

Baldwin, Robert E. 1969. “The Case against Infant Industry Tariff Protection." Journal of Political Economy 77 (3): 295-305.

Banerjee, Abhijit V., and Esther Duflo. 2014. "Do Firms Want to Borrow More? Testing Credit Constraints Using a Directed Lending Program." The Review of Economic Studies 81 (2): 572-607. https://doi.org/10.1093/restud/rdt046.

Bardhan, Pranab K. 1971. “On Optimum Subsidy to a Learning Industry: An Aspect of the Theory of Infant-Industry Protection." International Economic Review 12 (1): 54-70. https:/ / doi.org/10.2307/2525496.

Barrios, Salvador, and Eric Strobl. 2004. "Learning by Doing and Spillovers: Evidence from Firm-Level Panel Data." Review of Industrial Organization 25 (2): 175-203. https:/ / doi.org/10.1007/s11151-004-3536-y.

Barwick, Panle Jia, Myrto Kalouptsidi, and Nahim Bin Zahur. 2019. "China's industrial policy: An empirical evaluation." National Bureau of Economic Research.

Bau, Natalie, and Adrien Matray. 2021. "Misallocation and Capital Market Integration: Evidence From India."

Beason, Richard, and David E Weinstein. 1996. "Growth, Economies of Scale, and Targeting in Japan (1955-1990)." The Review of Economics and Statistics 78 (2): 286-95.

Becker, SO, PH Egger, and M Von Ehrlich. 2010. “Going NUTS: The effect of EU Structural Funds on regional performance." Journal of Public Economics.

Bellemare, Marc F, and Casey J Wichman. 2020. "Elasticities and the Inverse Hyperbolic Sine Transformation." Oxford Bulletin of Economics and Statistics 82 (1): 50-61. https://doi.org/10.1111/obes.12325.

Besley, Timothy, and Torsten Persson. 2010. “State Capacity, Conflict, and Development." Econometrica 78 (1): 1-34.

. 2011. Pillars of Prosperity: The Political Economics of Development Clusters. The Yrjö Jahnsson Lectures. Princeton, New Jersey: Princeton University Press.

Blonigen, Bruce A. 2016. "Industrial Policy and Downstream Export Performance." The Economic Journal 126 (595): 163559. https://doi.org/10.1111/ecoj.12223.

Blundell, Richard, and Monica Costa Dias. 2009. "Alternative Approaches to Evaluation in Empirical Microeconomics." The Journal of Human Resources 44 (3): 565-640.

Callaway, Brantly, and Pedro H C Sant'Anna. 2020. "Difference-in-differences with multiple time periods." Journal of Econometrics.

Castley, Robert. 1997. Korea's Economic Miracle: The Crucial Role of Japan. First. London; Basingstoke, U.K.: Palgrave Macmillan UK.

Cerqua, Augusto, and Guido Pellegrini. 2017. "Industrial policy evaluation in the presence of spillovers." Small Business Economics 49 (3): 671-86. https://doi.org/10.1007/s11187-017-9855-9.

Chang, Ha-Joon. 1993. "The political economy of industrial policy in Korea." Cambridge Journal of Economics 17 (2): 131-57.

Cheng, Tun-jen. 1990. "Political Regimes and Development Strategies." In Manufacturing Miracles: Paths of Industrialization in Latin America and East Asia, edited by Gary Gereffi and Donald L. Wyman, 139-78. Princeton, New Jersey: Princeton University Press.

— 2001. "Transforming Taiwan's Economic Structure in the 20th Century." In Taiwan in the Twentieth Century: A Retrospective View, edited by Richard Louis Edmonds and Steven M. Goldstein, 19-36. Cambridge, England: Cambridge University Press.

Chibber, Vivek. 2002. "Bureaucratic Rationality and the Developmental State." American Journal of Sociology 107 (4): $951-$ 89.

Cho, Yoon Je. 1989. "Finance and Development: The Korean Approach." Oxford Review of Economic Policy 5 (4): 88-102.

Cho, Yoon-Je, and David C Cole. 1986. The Role of the Financial Sector in Korea's Structural Adjustment. Development Discussion Paper. Harvard Institute for International Development, Harvard University.

Cho, Yoon-Je, and Joon-Kyung Kim. 1995. "Mean_rca_time." Washington, D.C.: The World Bank.

Choi, Tae Young, and Su Gyo Lee. 1989. "Effect analysis of US military aid to the Republic of Korea." Declassified, Naval Postgraduate School; Naval Postgraduate School Archive.

Choue, Inwon. 1988. "The politics of industrial restructuring: South korea's turn toward export-led heavy and chemical industrialization, 1961-1974." PhD thesis, University of Pennsylvania.

Corden, W Max. 1997. Trade Policy and Economic Welfare. Oxford: Oxford University Press. 
Costinot, Arnaud, Dave Donaldson, and Ivana Komunjer. 2012. “What Goods Do Countries Trade? A Quantitative Exploration of Ricardo's Ideas." The Review of Economic Studies 79 (2): 581-608. https: / / doi.org/10.1093 / restud / rdr03 3.

Criscuolo, Chiara, Ralf Martin, Henry Overman, John Van Reenen, and John Van Reenen. 2019. “Some Causal Effects of an Industrial Policy." American Economic Review 109 (1): 48-85. https:/ / doi.org/10.1257/aer.20160034.

Cushman, John H. 1979. “The Military Balance in Korea." Asian Affairs: An American Review 6 (6): 359-69.

Dell, Melissa, Nathan Lane, and Pablo Querubin. 2018. "The Historical State, Local Collective Action, and Economic Development in Vietnam." Econometrica 86 (6): 2083-2121. https://doi.org/10.3982/ECTA15122.

Diewert, Erwin. 2000. “The Challenge of Total Factor Productivity Measurement." International Productivity Monitor 1 (1): $45-52$.

Dollar, David, and Kenneth Sokoloff. 1990. "Patterns of productivity growth in South Korean manufacturing industries, 1963-1979." Journal of Development Economics 33 (2): 309-27.

Eberstadt, Nick. 1999. The End of North Korea. Washington, D.C.: The AEI Press.

Evans, Peter B. 1992. "The State as Problem and Solution: Predation, Embedded Autonomy, and Structural Change." In The Politics of Economic Adjustment: International Constraints, Distributive Conflicts and the State, edited by Stephan Haggard and Robert R. Kaufman, 139-81. Princeton, New Jersey: Princeton University Press.

. 1995. Embedded Autonomy: States and Industrial Transformation. Princeton, New Jersey: Princeton University Press.

Felipe, Jesus. 1999. "Total factor productivity growth in East Asia: A critical survey." The Journal of Development Studies 35 (4): 1-41. https://doi.org/10.1080/00220389908422579.

Fernald, John, and Brent Neiman. 2011. "Growth accounting with misallocation: Or, doing less with more in Singapore." American Economic Journal: Macroeconomics 3 (2): 29-74.

Fernandes, Ana M, and Alberto E. Isgut. 2005. “Learning-by-Doing, Learning-by-Exporting, and Productivity : Evidence from Colombia." World Bank Policy Research Working Paper. Washington, D.C.: World Bank.

Frank, Charles R, Jr., Kwang Suk Kim, and Larry E Westphal. 1975. Foreign Trade Regimes and Economic Development: South Korea. New York: National Bureau of Economic Research; Columbia University Press.

Fukuyama, Francis. 2014. Political Order and Political Decay, from the industrial revolution to the Globalization of Democracy. First. New York, New York: Farrar, Straus,; Giroux.

Giorcelli, Michela. 2019. "The Long-Term Effects of Management and Technology Transfers." American Economic Review 109 (1): 1-33.

Goldberg, P K, and N Pavcnik. 2016. "Chapter 3 - The Effects of Trade Policy." In, edited by Kyle Bagwell and Robert W B T - Handbook of Commercial Policy Staiger, 1:161-206. North-Holland. https:/ /doi.org/10.1016/bs.hescop.2016.04. 002.

Gorton, Gary, and Guillermo Ordoñez. 2020. "Good Booms, Bad Booms." Journal of the European Economic Association 18 (2): 618-65. https://doi.org/10.1093/jeea/jvy058.

Grossman, Gene M. 1990. “Promoting New Industrial Activities: A Survey Of Recent Arguments And Evidence." OECD Journal: Economic Studies, no. 14: 87-125.

Gruber, Harald. 1998. "Learning by Doing and Spillovers: Further Evidence for the Semiconductor Industry." Review of Industrial Organization 13 (6): 697-711. https://doi.org/10.1023/A:1007740416004.

Haggard, Stephan. 1990. The Politics of Growth in the Newly Industrializing Countries. First. Ithaca, New York; London, U.K.: Cornell University Press.

Hamm, Taik-young. 1999. Arming the Two Koreas: State, Capital and Military Power. Vol. 10. London, England; New York, New York: Routledge.

Han, Sungjoo. 1978. "South Korea 1977: Preparing for Self-Reliance." Asian Survey 18 (1): 45-57.

Han, Taehwan. 1998. "A Comparison of Industrial Policies Between Japan and Korea: The Roles of MITI and EPB in Heavy and Automobile Industries Promotion." PhD thesis, University of Hawaii.

Hanlon, W Walker. 2020. "The Persistent Effect of Temporary Input Cost Advantages in Shipbuilding, 1850 to 1911." Journal of the European Economic Association 18 (6): 3173-3209. https:/ /doi.org/10.1093/jeea/jvz067.

Harris, Richard, Ian Keay, and Frank Lewis. 2015. "Protecting infant industries: Canadian manufacturing and the national policy, 1870-1913." Explorations in Economic History 56: 15-31. https://doi.org/10.1016/j.eeh.2015.01.001.

Harrison, Ann E, and Andres Rodriguez-Clare. 2009. "Trade, Foreign Investment, and Industrial Policy for Developing Countries." In Handbook of Development Economics, Volume 5, edited by Dani Rodrik and Mark Rosenzweig, $4039-4214$. Amsterdam, The Netherlands: Elsevier B.V.; North-Holland.

Head, Keith. 1994. "Infant Industry Protection in the Steel Rail Industry." Journal of International Economics 37 (3): 141-65. https://doi.org/10.1016/0022-1996(94)90043-4.

Heckman, James, Hidehiko Ichimura, Jeffrey Smith, and Petra Todd. 1998. “Characterizing Selection Bias Using Experimental Data." Econometrica, Econometrica, 66 (5): 1017-98. https:/ / doi.org/DOI: ,.

Herrera, Ana María. 2018. “OIL PRICE SHOCKS, INVENTORIES, AND MACROECONOMIC DYNAMICS.” Macroeconomic Dynamics 22 (3): 620-39. https://doi.org/10.1017/S1365100516000225.

Hirschman, Albert O. 1958. The Strategy of Economic Development. Third. New Haven, Connecticut: Yale University Press.

Hong, Wontack. 1977. "TRADE, DISTORTIONS AND EMPLOYMENT GROWTH IN KOREA.” KDI Working Paper Series/Korea Modernization Series. Seoul: Korean Development Institute. . 1987. "Export-Oriented Growth and Trade Patterns of Korea." In Trade and Structural Change in Pacific Asia, edited by Jr Colin I. Bradford and William H. Branson, 273-306. Chicago, Illinois: University of Chicago Press.

Horikane, Yumi. 2005. "The Political Economy of Heavy Industrialisation: The Heavy and Chemical Industry (HCI) Push in South Korea in the 1970s." Modern Asian Studies 39 (2): 369-97.

International Bank for Reconstruction and Development. 1974. "Current Economic Position and Prospects of the Republic of Korea: Volume I." Washington, D.C.: East Asia; Pacific-Department Asia Region of International Bank for Reconstruction; Development.

Inwood, Kris, and Ian Keay. 2013. "Trade policy and industrial development: iron and steel in a small open economy, 1870-1913." Canadian Journal of Economics/Revue Canadienne d'économique 46 (4): 1265-94. https:/ / doi.org/10.1111/ca je.12048. 
Irwin, Douglas A. 2000. “Did Late-Nineteenth-Century U.S. Tariffs Promote Infant Industries? Evidence from the Tinplate Industry." The Journal of Economic History 60 (2): 335-60. https:/ / doi.org/10.1017/S0022050700025122.

Jaworski, Taylor, and Andrew Smyth. 2018. "Shakeout in the early commercial airframe industry." The Economic History Review 71 (2): 617-38. https://doi.org/10.1111/ehr.12430.

Johnson, Chalmers. 1982. MITI and the Japanese Miracle: The Growth of Industrial Policy : 1925-1975. Stanford, California: Stanford University Press.

Juhasz, Reka. 2018. “Temporary Protection and Technology Adoption: Evidence from the Napoleonic Blockade." American Economic Review 108 (11): 3339-76. https:/ / doi.org/10.1257/aer.20151730.

Kalouptsidi, Myrto. 2018. "Detection and Impact of Industrial Subsidies: The Case of Chinese Shipbuilding." The Review of Economic Studies 85 (2): 1111-58. https://doi.org/10.1093/restud/rdx050.

Kamada, Tomihisa, and Satoru Kawai. 1989. "An Algorithm for Drawing General Undirected Graphs." Information Processing Letters 31 (1): 7-15.

Kaneda, Mitsuhiro. 2003. "Policy designs in a dynamic model of infant industry protection." Journal of Development Economics 72 (1): 91-115. https:/ / doi.org/10.1016/S0304-3878(03)00069-5.

Kim, Byung-kook. 2011. "The Laviathan: Economic bureaucracy under Park." In The Park Chung Hee Era: The Transformation of South Korea, edited by Byung-kook Kim and Ezra Vogel, 200-233. Cambridge, Massachusetts; London, England: Harvard University Press.

Kim, Chung-yum. 2011. “From Despair to Hope : Economic Policymaking in Korea, 1945-1979." In. Seoul, Korea: Korea Development Institute.

Kim, Do Hoon DaHoon, Young Seok Oh, Kye Hwan Kim, Ma Joy V. Abrenca, Mauricio Canedo Pinheiro, and Chen Tsung Yun. 2013. "A Study on International Comparisons of Processes and Policies for Developing Heavy and Chemical Industries." Research Report. Seoul: Korea Institute for Industrial Economics; Trade.

Kim, Eun Mee. 1988. "From Dominance to Symbiosis: State and Chaebol in Korea." Pacific Focus 3 (2): 105-21.

1997. Big Business, Strong State: Collusion and Conflict in South Korean Development, 1960-1990. Albany, New York: State University of New York Press.

Kim, Hyung-A. 2004. Korea's Development Under Park Chung Hee: Rapid Industrialization, 1961-1979. Routledge/Asian Studies Association of Australia (ASAA) East Asian Series. Abingdon, UK; New York, NY: Routledge; Taylor \& Francis Group.

_. 2011. "Heavy and Chemical Industrialization, 1973-1979: South Korea's Homeland Security Measures." Reassessing the Park Chung Hee Era, 1961-1979; Development, Political Thought, Democracy, \& Cultural Influence.

Kim, Ji Hong. 1990. “Korean Industrial Policy in the 1970's: The Heavy and Chemical Industry Drive." Seoul: Korea Development Institute.

Kim, Jong Kil. 1981. "The Incentive Structure for Industrialization in a Developing Economy: The Case of Korea." PhD thesis, University of Connecticut.

Kim, Joon-Kyung, Sang Dal Shim, and Jun-Il Kim. 1995. "The Role of Government in Promoting Industrialization and Human Capital Accumulation in Korea." In Growth Theories in Light of the East Asian Experience, NBER-EASE Volume 4, edited by Takatoshi Ito and Anne O. Krueger, 181-200. Chicago, Illinois: University of Chicago Press.

Kim, Kihwan, and Danny M Leipziger. 1993. "Korea: a Case of Government-Led Development." In The Lessons of East Asia, Third. Washington, D.C.: World Bank Publications.

Kim, Kwang Suk. 1994. "Trade and Industrialization Policies in Korea: An overview." In Trade Policy and Industrialization in Turbulent Times, edited by Gerald K. Helleiner, First, 317-63. New York, New York: Routledge.

Kim, Se Jin. 1970. "South Korea's Involvement in Vietnam and Its Economic and Political Impact." Asian Survey 10 (6): 519-32.

Kim, Seung-Young. 2001. "Security, nationalism and the pursuit of nuclear weapons and missiles: The South Korean case, 1970-82." Diplomacy and Statecraft 12 (4): 53-80.

Kohli, Atul. 2004. State-Directed Development: Political Power and Industrialization in the Global Periphery. Cambridge, U.K.: Cambridge University Press.

Kong, Tat Yan. 2000. The Politics of Economic Reform in South Korea: A Fragile Miracle. Routledge Advances in Korean Studies. London, England; New York, New York: Routledge; Taylor \& Francis Group.

Koo, Bohn-Young. 1984. "The Role of the Government in Korea's Industrial Development: A paper submitted to the U.S.I.T.C. for its Study on 'Industrial Targeting Practices in Korea'." Seoul: Korea Development Institute.

Krueger, Anne O. 1979. The Developmental Role of the Foreign Sector and Aid. Cambridge, Massachusetts; London, England: Council on East Asian Studies, Harvard University; Harvard University Press.

- 1990. "Government Failures in Development." The Journal of Economic Perspectives 4 (3): 9-23.

- 1995. "East Asian Experience and Endogenous Growth Theory." In Growth Theories in Light of the East Asian Experience, NBER-EASE Volume 4, 9-36. Chicago, Illinois: University of Chicago Press.

Krueger, Anne O., and Baran Tuncer. 1982. "An Empirical Test of the Infant Industry Argument." American Economic Review 72 (5): 1142-52.

Krugman, Paul R. 1993. “The Current Case for Industrial Policy." In Protectionism and World Welfare, edited by Dominick Salvatore, 160-79. Cambridge, U.K; New York, New York: Cambridge University Press.

Kwack, Taewon. 1984. "Industrial Restructuring Experience and Policies in Korea in the 1970s." KDI Working Paper Series. Seoul: Korean Development Institute.

- 1985. "Depreciation and Taxation of Income from Capital." Seoul, Korea: Korean Development Institute.

Kwack, Taewon, and Kye-Sik Lee. 1992. "Tax Reform in Korea." In The Political Economy of Tax Reform, NBER-East Asia Seminar on Economics Volume 1, edited by Takatoshi Ito and Anne O. Krueger, First, 117-36. Chicago, Illinois; London, England: University of Chicago Press.

Kwak, Tae Yang. 2003. "The Nixon Doctrine and the Yusin Reforms: American Foreign Policy, the Vietnam War, and the Rise of Authoritarianism in Korea, 1968-1973." Journal of American-East Asian Relations 12 (1): 33-34.

Kwang Mo, Kim. 2015. (The spirit of Park Chung-hee lives on in the heavy and chemical industry: A Record of History) 중화학 공 업 에 박 정희 의 혼 이 살아 있다: 청와대 비서관 이 엮은'역사 의 기록. Seoul: 기파랑. 
Lall, Sanjaya. 1995. “Malaysia: Industrial success and the role of the government." Journal of International Development 7 (5): 759-73.

_ 1996. “The East Asian Miracle' Study: Does the Bell Toll for Industrial Strategy?” In Learning from the Asian Tigers: Studies in Technology and Industrial Policy, edited by Sanjaya Lall, 107-23. London, England: Palgrave Macmillan UK.

- 1997. "Selective Policies for Export Promotion Lessons from Asian Tigers - Lall WP 1997." Research for Action 43. Helsinki: UNU World Institute for Development Economics Research.

Lane, Nathan. 2020. "The New Empirics of Industrial Policy." Journal of Industry, Competition and Trade 1 (2): 1-26. https: //doi.org/10.1007/s10842-019-00323-2.

Lawrence, Robert Z, and David E Weinstein. 1999. “Trade and growth: import-led or export-led? Evidence from Japan and Korea." National bureau of economic research.

Lee, Jong-Wha. 1996. "Government Interventions and Productivity Growth.” Journal of Economic Growth 1 (3): 391-414.

Lee, Kyung Tae. 1992. “Korea's Economic Development; Market-Pulled or Government-Pushed?” Korea Institute for Industrial Economics; Trade.

Lee, Nae-young. 2011. "The Automobile Industry." In The Park Chung Hee Era: The Transformation of South Korea, edited by Byung-Kook Kim and Ezra F. Vogel, 295-321. Cambridge, Massachusetts; London, England: Harvard University Press.

Lee, Suk-Chae. 1991. “The Heavy and Chemical Industries Promotion Plan (1973-1979)." In Economic Development in the Republic of Korea: A Policy Perspective, edited by Lee-Jay Cho and Yoon Hyung Kim, 431-71. Honolulu, Hawaii: EastWest Center, University of Hawaii Press.

Levinsohn, J, and Amil Petrin. 2003. "Estimating production functions using inputs to control for unobservables." The Review of Economic Studies 70 (2): 317-41.

Lim, Youngil. 1981. Government Policy and Private Enterprise: Korean Experience in Industrialization. 1st ed. Berkeley: Center for Korean Studies, Institute of East Asia Studies, University of California at Berkeley.

Lin, Justin Yifu. 2012. New Structural Economics: A Framework for Rethinking Development and Policy. Vol. 26. 2. Washington, D.C.: The World Bank.

Liu, Ernest. 2019. "Industrial Policies in Production Networks." Quarterly Journal of Economics, no. Forthcoming.

Lucas, Robert E B. 1984. “An Empirical Test of the Infant Industry Argument: Comment.” The American Economic Review 74 (5): 1110-11.

Luedde-Neurath, Richard. 1986. Import controls and Export-Oriented Development: a Reassessment of the South Korean case. Boulder, Colorado; Londong, England: Westview Press.

Man, Bae Suk. 2019. "Negotiations between Korea and Japan over Economic Development during the Park Chung-hee Regime - Focusing on 'Four Core Factory Construction Plan' (Korean)." 경제사학 43 (1): 43-77.

Manova, Kalina, Shang-Jin Wei, and Zhiwei Zhang. 2015. "Firm exports and multinational activity under credit constraints." Review of Economics and Statistics 97 (3): 574-88.

Martin, Leslie A, Shanthi Nataraj, and Ann E Harrison. 2017. "In with the Big, Out with the Small: Removing Small-Scale Reservations in India." American Economic Review 107 (2): 354-86.

Mendoza, Enrique G, and Marco E Terrones. 2008. “An anatomy of credit booms: evidence from macro aggregates and micro data." National Bureau of Economic Research.

Mitrunen, Matti. 2019. "War Reparations, Structural Change, and Intergenerational Mobility."

Moon, Chung-in, and Byung-joon Jun. 2011. "Modernization Strategy: Ideas and Influences." In The Park Chung Hee Era: The Transformation of South Korea, edited by Byung-Kook Kim and Ezra F. Vogel, 115-39. Cambridge, Massachusetts; London, England: Harvard University Press.

Moon, Chung-in, and Sangkeun Lee. 2009. "Military Spending and the Arms Race on the Korean Peninsula." Asian Perspective 33 (4): 69-99.

Moreira, Mauricio Mesquita. 1994. "Industrialization, Trade and Market Failures: the Role of Government Intervention in Brazil." Revista Brasileira de Economia 48 (3): 295-324.

Nam, Chong-Hyun. 1980. "Trade and Industrial Policies, and the Structure of Protection in Korea." Seoul: Korea Development Institute.

Nam, Sang-Woo. 1992. “Korea's financial reform since the early 1980s." In Financial Reform: Theory and Experience, edited by Gerard Caprio, Izak Atiyas, and James A. Hanson, 184-222. New York, New York: Cambridge University Press.

Nelson, Richard R, and Howard Pack. 1999. "The Asian Miracle and Modern Growth Theory." The Economic Journal 109 (457): 416-36.

Neumark, David, and Helen Simpson. 2015. “Place-Based Policies." In Handbook of Regional and Urban Economics, edited by Gilles Duranton, J Vernon Henderson, and William C Strange, 5:1197-287. Elsevier. https://doi.org/10.1016/B9 78-0-444-59531-7.00018-1.

Nixon, Richard M. 1969. Public Papers of the Presidents of the United States - Richard Nixon. Washington, D.C.: Office of the Federal Register, Government Printing Office.

- 1970. "Letter From President Nixon to Korean President Park." In Foreign Relations of the United States, 1969-1976, edited by Edward C Keefer and Carolyn Yee, 2010th ed., XIX:152-54. Washington, D.C.: United States Government Printing Office.

Noland, Marcus. 2004. "Selective Intervention and Growth: The Case of Korea." In Empirical Methods in International Trade: Essays in Honor of Mordechai Kreinin, edited by Michael G. Plummer, 229-46. August. Cheltenham, UK; Northampton, MA: Edward Elgar.

Noland, Marcus, and Howard Pack. 2003. Industrial Policy in an Era of Globalization: Lessons from Asia. Washington, D.C.: Institute for International Economics.

Nunn, Nathan, and Daniel Trefler. 2010. “The Structure of Tariffs and Long-Term Growth." American Economic Journal: Macroeconomics 2 (4): 158-94.

Nurkse, Ragnar. 1953. Problems of Capital Formation in Underdeveloped Countries. Oxford, UK: Oxford University Press.

Okazaki, Tetsuji. 1998. "Industrial Policy and Government Organization in Postwar Japan (in Japanese)." CIRJE-J-2. CIRJE j-Series. CIRJE, Faculty of Economics, University of Tokyo. https://doi.org/DOI: 
Olden, Andreas, and Jarle Men. 2022. "The triple difference estimator." The Econometrics Journal, March, utac010. https: //doi.org/10.1093/ectj/utac010.

Olley, G Steven, and Ariel Pakes. 1996. "The Dynamics of Productivity in the Telecommunications Equipment Industry." Econometrica 64 (6): 1263-97. https:/ / doi.org/10.2307/2171831.

Ostermann, Christian F., and James F. Person. 2011. “The rise and fall of Détente on the Korean Peninsula, 1970-1974." In History and Public Policy Program Critical Oral History Conference Series, edited by Christian F Ostermann and James F Person. Washington, D.C.: Woodrow Wilson International Center for Scholars.

Pack, Howard. 2000. "Industrial Policy: Growth Elixir or Poison?" The World Bank Research Observer 15 (1): 47-67.

Pack, Howard, and Kamal Saggi. 2006a. "Is there a case for industrial policy? A critical survey." The World Bank Research Observer 21 (2): 267-97.

_ 2006b. "Is There a Case for Industrial Policy? A Critical Survey." The World Bank Research Observer 21 (2): $267-97$. https://doi.org/10.1093/wbro/lk1001.

Park, Tong-Ho. 1977. "A Study on the Industry Tariff System of Korea - with refer to Heavy \& Chemical Industry Development" 4 (5): 173-214.

Perkins, Dwight H. 2013. East Asian Development: Foundations and Strategies (The Edwin O. Reischauer Lectures). Cambridge, Massachusetts; London, England: Harvard University Press.

Pons-Benaiges, Oriol. 2017. “Did Government Intervention Target Technological Externalities? Industrial Policy and Economic Growth in Postwar Japan, 1964-1983."

Rasmussen, Poul Nørregaard. 1956. Studies in Inter-Sectoral Relations. First. (København) Copenhagen, Denmark: E. Harck.

Redding, Stephen. 1999. “Dynamic Comparative Advantage and the Welfare Effects of Trade." Oxford Economic Papers 51 (1): 15-39.

Rhyu, Sang-young, and Seok-jin Lew. 2011. “Pohang Iron \& Steel Company.” In The Park Chung Hee Era: The Transformation of South Korea, edited by Byung-kook Kim and Ezra Vogel, 322-44. Cambridge, Massachusetts; London, England: Harvard University Press.

Robinson, James A. 2010. "Industrial Policy and Development: A Political Economy Perspective." In Annual World Bank Conference on Development Economics 2010 - Global: Lessons from East Asia and the Global Financial Crisis, edited by Justin Yifu Lin and Boris Pleskovic, 61-79. Washington, D.C.: The World Bank.

Rodriguez, Francisco, and Dani Rodrik. 2001. "Trade Policy and Economic Growth: A Skeptic's Guide to the CrossNational Evidence." In NBER Macroeconomics Annual 2000, Volume 15, 15:261-338. January. University of Chicago Press. https://doi.org/10.1086/654419.

Rodriguez-Clare, Andres. 2007. "Clusters and comparative advantage: Implications for industrial policy." Journal of Development Economics 82 (1): 43-57.

Rodrik, Dani. 1995a. “Getting Interventions Right: How South Korea and Taiwan Grew Rich.” Economic Policy 10 (20): $53-$ 107.

_. 1995b. "Trade and industrial policy reform." In Handbook of Development Economics, 3B:2925-82. Elsevier. https: //doi.org/10.1016/S1573-4471(95)30022-8.

- 2004. "Industrial Policy for the Twenty-First Century." John F. Kennedy School of Government. . 2005. "Growth Strategies." In Handbook of Economic Growth, edited by Philippe Aghion and Steven N. Durlauf, 1:967-1014. Amsterdam, The Netherlands: Elsevier B.V.; North-Holland.

Rogers, William P. 1970. "Telegram From the Department of State to the Embassy in Korea." In Foreign Relations of the United States, 1969-1976, edited by Edward C Keefer and Carolyn Yee, 2010th ed., XIX:150-52. Washington, D.C.: United States Government Printing Office.

Rosenberg, Nathan. 1976. Perspectives on Technology. Cambridge: Cambridge University Press.

Rosenstein-Rodan, Paul N. 1943. "Problems of Industrialisation of Eastern and South-Eastern Europe." The Economic Journal 53 (210/211): 202-11.

Rotemberg, Martin. 2017. "Equilibrium Effects of Firm Subsidies."

Sant'Anna, Pedro H C, and Jun Zhao. 2020. "Doubly robust difference-in-differences estimators." Journal of Econometrics 219 (1): 101-22.

Schmitz Jr, James A. 2001. “Government production of investment goods and aggregate labor productivity." Journal of Monetary Economics 47 (1): 163-87.

Scitovsky, Tibor. 1954. “Two Concepts of External Economies.” Journal of Political Economy 62 (2): 143-51.

Scobell, Andrew, and John M. Sanford. 2007. "North Korea's Military Threat: Pyongyang's Conventional Forces, Weapons of Mass Destruction, and Ballistic Missiles." Carlisle Barracks, Pennsylvania: U.S. Army War College Strategic Studies Institute.

Silva, J M C Santos, and Silvana Tenreyro. 2006. “The Log of Gravity.” The Review of Economics and Statistics 88 (4): $641-58$. https://doi.org/10.1162/rest.88.4.641.

Sloczynski, Tymon. 2018. "A General Weighted Average Representation of the Ordinary and Two-Stage Least Squares Estimands." Working Papers. Brandeis University, Department of Economics; International Businesss School. https: //doi.org/DOI:

Stern, Joseph J, Ji-hong Kim, Dwight H Perkins, and Jung-ho Yoo. 1995. Industrialization and the State: The Korean Heavy and Chemical Industry Drive. Cambridge, Massachusetts: Harvard Institute for International Development.

Succar, Patricia. 1987. "The Need for Industrial Policy in LDC's - A Restatement of the Infant Industry Argument." International Economic Review 28 (2): 521-34. https:/ / doi.org/10.2307/2526741.

Taylor, William J, Jennifer A Smith, and Michael J Mazarr. 1990. “US Troop Reductions from Korea, 1970-1990." The Journal of East Asian Affairs 4 (2): 256-86.

The World Bank. 1993. The East Asian Miracle: Economic Growth and Public Policy: A World Bank Policy Research Report. London: Oxford University Press.

Thompson, Peter. 2001. "How Much Did the Liberty Shipbuilders Learn? New Evidence for an Old Case Study." Journal of Political Economy 109 (1): 103-37. https:/ / doi.org/10.1086/318605. 
2010. "Chapter 10 - Learning by Doing." In Handbook of the Economics of Innovation, Vol. 1, edited by Bronwyn H Hall and Nathan B T - Handbook of the Economics of Innovation Rosenberg, 1:429-76. North-Holland. https:/ doi. org/10.1016/S0169-7218(10)01010-5.

Thornton, Rebecca Achee, and Peter Thompson. 2001. "Learning from Experience and Learning from Others: An Exploration of Learning and Spillovers in Wartime Shipbuilding." American Economic Review 91 (5): $1350-68$.

Trager, Frank N. 1972. "The Nixon Doctrine and Asian Policy." Southeast Asian Perspectives, no. 6: 1-34.

Trela, Irene, and John Whalley. 1990. "Taxes, outward orientation, and growth performance in Korea." Policy, Research, and External Affairs Working Paper Series. Washington, D.C.: The World Bank.

Van Beveren, Ilke. 2012. "TOTAL FACTOR PRODUCTIVITY ESTIMATION: A PRACTICAL REVIEW." Journal of Economic Surveys 26 (1): 98-128. https:/ / doi.org/10.1111/j.1467-6419.2010.00631.x.

Vu, Tuong. 2010. Paths to Development in Asia South Korea, Vietnam, China, and Indonesia. New York, NY: Cambridge University Press.

Wade, Robert H. 1990. Governing the market: Economic theory and the role of government in East Asian industrialization. Second. Princeton, New Jersey: Princeton University Press.

Weinstein, David E. 1995. "Evaluating administrative guidance and cartels in Japan (1957-1988)." Journal of the Japanese and International Economies 9: 200-223.

Westphal, Larry E. 1990. "Industrial Policy in an Export Propelled Economy: Lessons from South Korea's Experience." Journal of Economic Perspectives 4 (3): 41-59.

Westphal, Larry E, and Kwang Suk Kim. 1982. "Fostering Technological Mastery by Means of Selective Infant Industry Protection." In Development Strategies in Semi-Industrial Economies, edited by Bela Balassa, 212-79. Baltimore, Maryland: Johns Hopkins University Press.

Woo, Jung-en. 1991. Race to the Swift: State and Finance in Korean Industrialization. New York, New York: Columbia University Press.

Woo-Cumings, Meredith Jung-En. 1998. "14 National security and the rise of the developmental state in South Korea and Taiwan." Behind East Asian Growth: The Political and Social Foundations of Prosperity, 319.

Wooldridge, Jeffrey M. 2009. "On estimating firm-level production functions using proxy variables to control for unobservables." Economics Letters 104 (3): 112-14. https:/ / doi.org/10.1016/j.econlet.2009.04.026.

World Bank. 1987. "Korea - Managing the industrial transition : The conduct of industrial policy." Washington, D.C.: The World Bank.

Yoo, Jung-ho. 1990. "The Industrial Policy of the 1970s and the Evolution of the Manufacturing Sector in Korea." 9017. Seoul, Korea: Korea Development Institute; Korea Development Institute.

Yoshioka, Shinji, and Hirofumi Kawasaki. 2016. "Japan's High-Growth Postwar Period: The Role of Economic Plans." Tokyo: Cabinet Office (CAO) Government of Japan, Economic; Social Research Institute.

Young, Alwyn. 1991. "Learning by Doing and the Dynamic Effects of International Trade." The Quarterly Journal of Economics 106 (2): 369-405. https:/ / doi.org/10.2307/2937942.

Zeile, William John. 1993. "Industrial targeting, business organization, and industry productivity growth in the Republic of Korea, 1972-1985." PhD thesis, Ann Arbor: University of California, Davis. 
Figure 1: Political Events Surrounding HCI - US Withdrawal and Korean Provocations
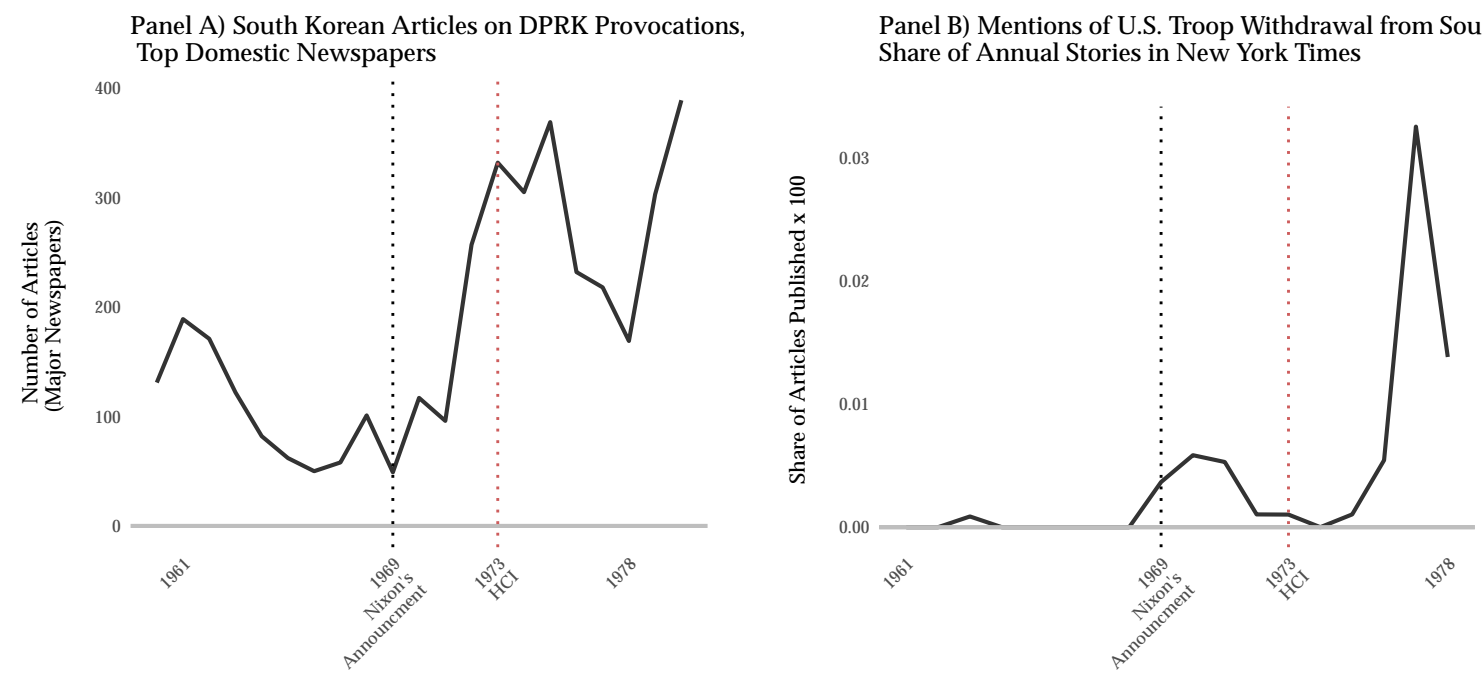

Notes: Figure shows the military-political crisis facing South Korea via U.S. and South Korean media. Panel A (left) shows the number of articles (count) in Donga and Kyunghyang newspapers matching a Korean-language dictionary of 'provocation' keywords (examples in text). I provide a list of Korean-language terms in the Online Appendix, which also details the selection of these terms using "'word2vector"'style models. The count includes articles matching dictionary terms that appear before page 5 . The 'provocation' count in panel B matches the same count by Choi (1989) of DPRK actions violating the Korean War armistace, shown in Figure 1 of Online Appendix. Panel B (right) shows the share of New York Times news stories referring to troop withdrawal. Share is measured as the total number of full-text article hits divided by number of stories published (times 100). The search term used is 'South Korea+Troop Withdrawal' via The New York Times (Lab). 
Figure 2: Public Finance and Specialized State Lending, Before, During, and After HCI

Panel A - Tax Rates on Marginal Returns to Capital, 1969-1983

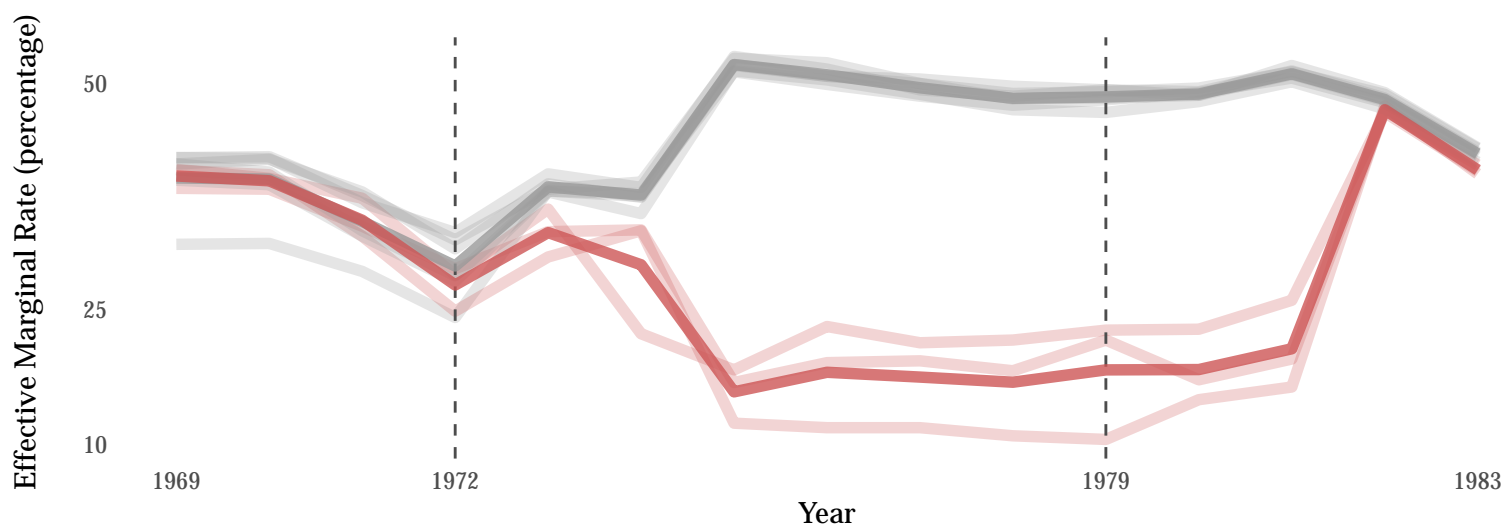

Year

Panel B - New Total Lending by Korean Development Bank

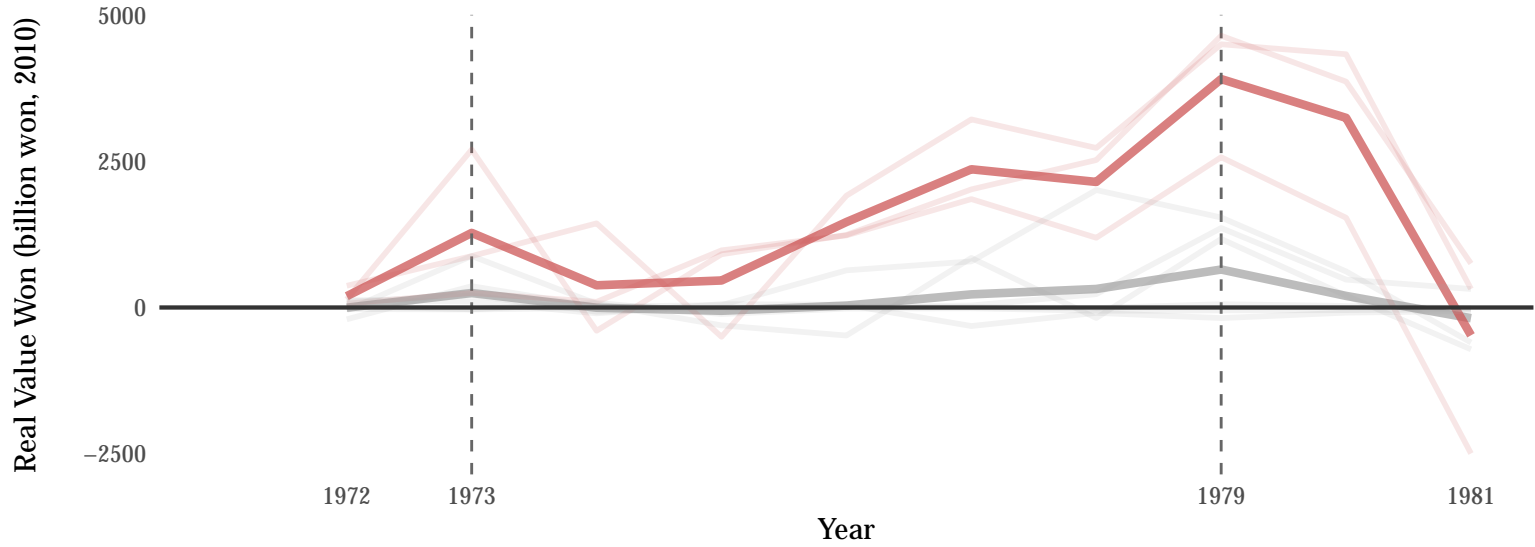

Panel C - New Machinery Lending by Korean Development Bank

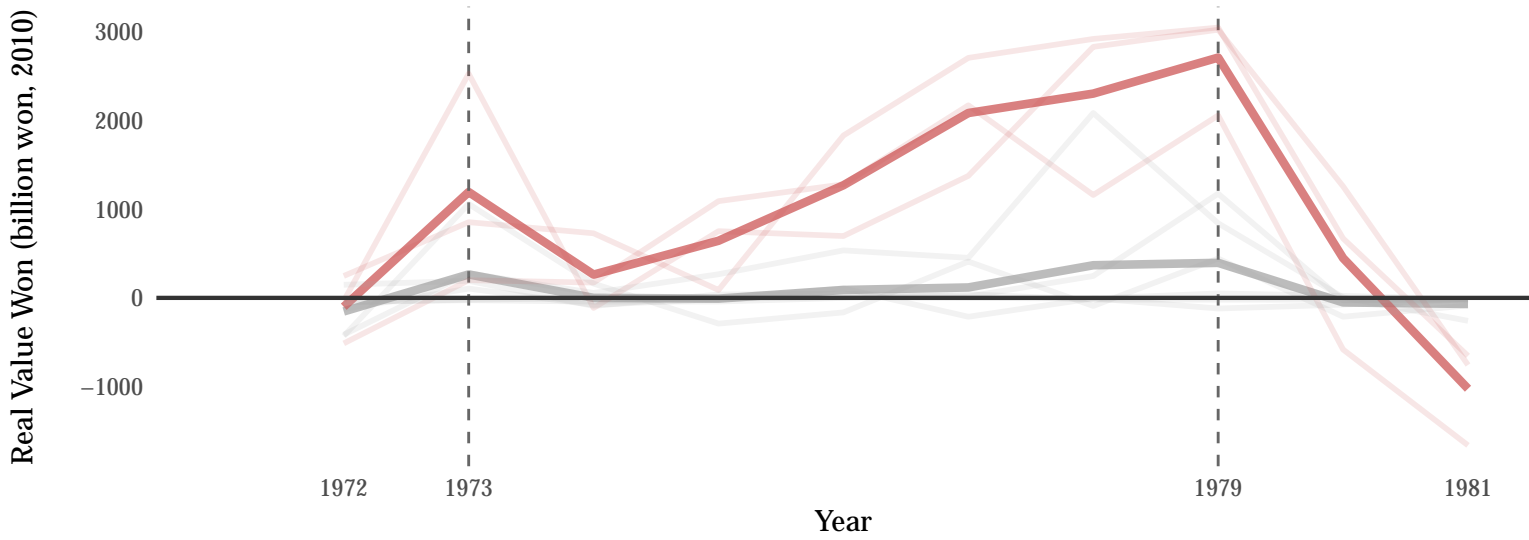

Type of Industry Non-HCI Manufacturing $=$ HCI Manufacturing

Notes: Top - Panel A plots estimates of the average effective marginal tax rate (percentage) on the returns of capital, accounting for changes in industry-specific tax subsidies, 1969-1983. Effective rates estimated for aggregate 2-digit manufacturing industries (thin lines). Thick lines show the rates by treated and non-treated industries. Source: see text and online appendix for documentation. Middle - Panel B plots the change in the (real) value of total loans issued by the Korea Development Bank, 1972-1981, a representative state lending bank. Bottom - Panel C plots the change in _only_ changes in lending for machinery, which was a major component of HCI lending and policy loans. See text for details on KDB lending and policy loans. For B and C, units are real value in 2010 won (billions). Gray lines correspond to non-targeted sectors and red lines correspond to targeted sectors. Thick lines are averages. Source: Korean Yearbooks, multiple years. 
Figure 3: Differences in Industrial Output (Real Value Shipped), HCI v. Non-HCI Industry

A) 5-Digit Panel - 1970-1986
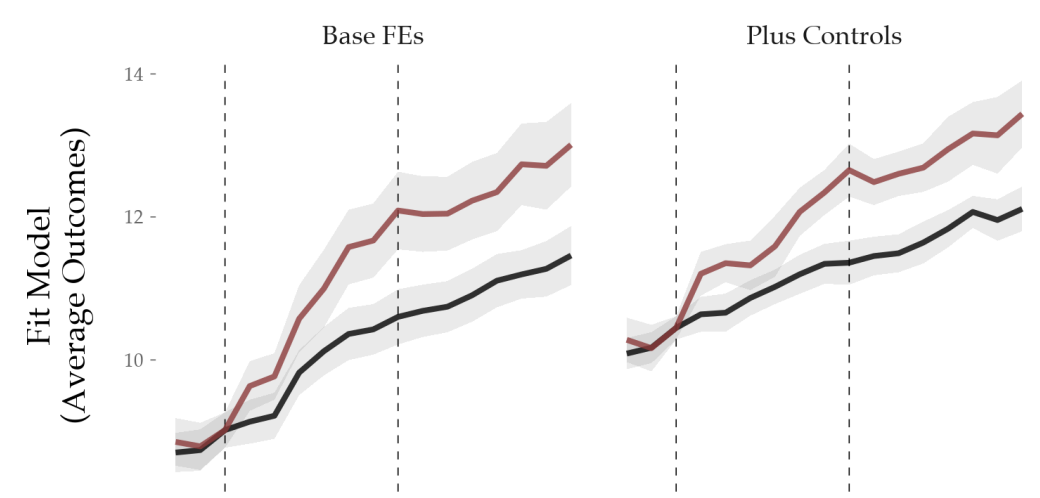

$\$$
B) 4-Digit Panel - 1967-1986
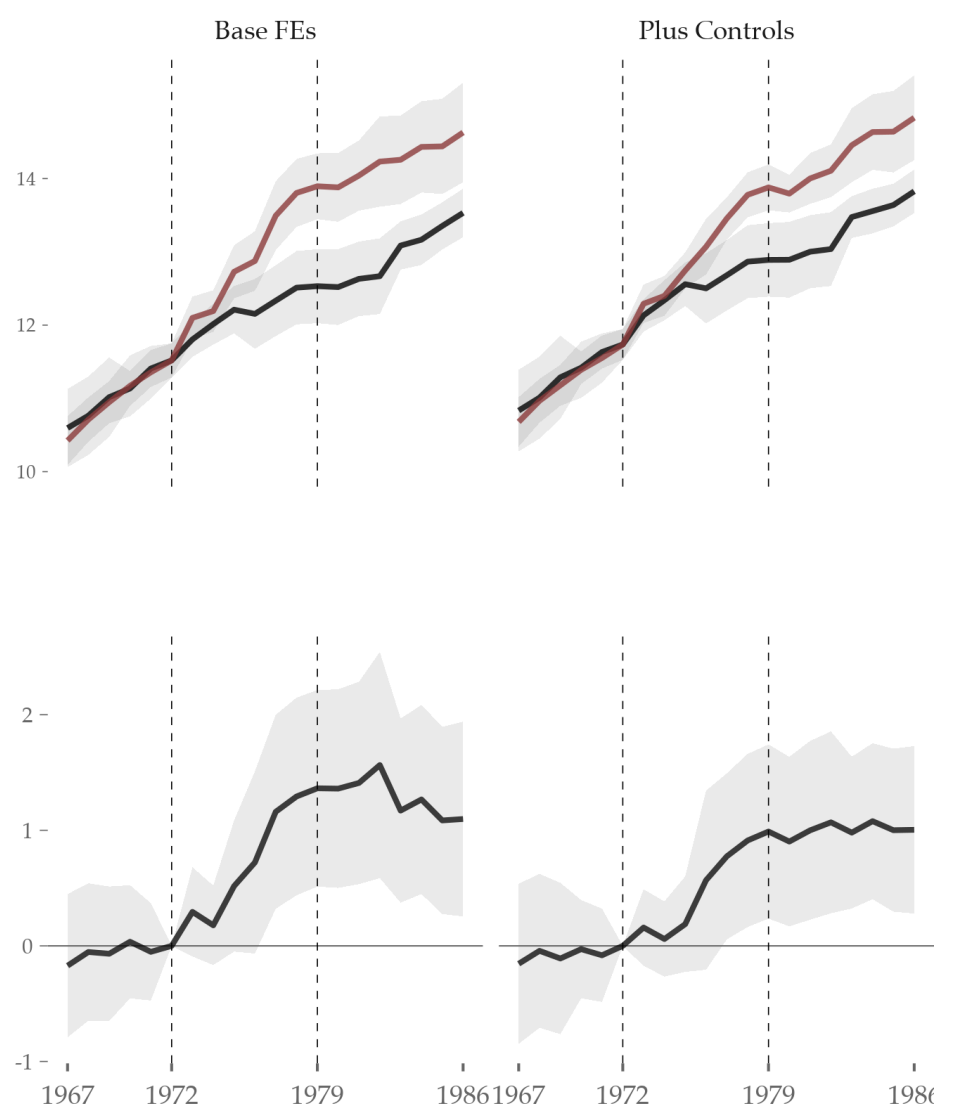

- Non-HCI

$-\mathrm{HCI}$

Note: Figure shows dynamic differences-in-differences estimates for the relationship between HCI and real value of output shiped. Top row plots averages for HCI (red) and non-HCI industry (black), or the fit DD model. Bottom row shows dynamic DD estimates. Panel A corresponds to estimates for detailed (short) 5-digit level panel. Panel B corresponds to estimates for aggregate (long) 4-digit level panel. 'Base FEs' are baseline regressions with two-way fixed effects. 'Plus Controls' are specifications with full pre-treatment controls, interacted with time effects. Estimates are relative to 1972, the year before the HCI policy. 1973 is the start of HCI. The line at 1979 demarcates the fall of the Park regime. Standard errors are clustered at the industry-level and corrected for heteroskedasticity. Confidence bands are in light grey and are 95 percent confidence intervals. 
Figure 4: Impact of HCI on (A) Industrial Development and (B) Trade Development

Panel A - Industrial Developmet

4-Digit Panel, 1967-1986

5-Digit Panel, 1970-1986

Labor Prod.
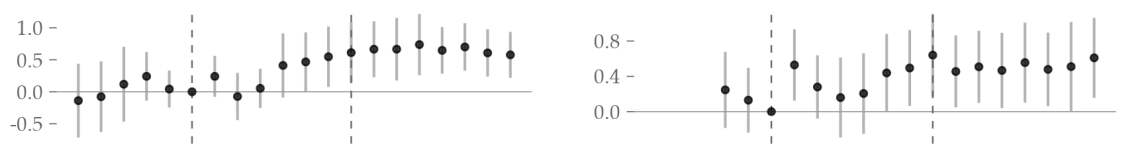

Prices
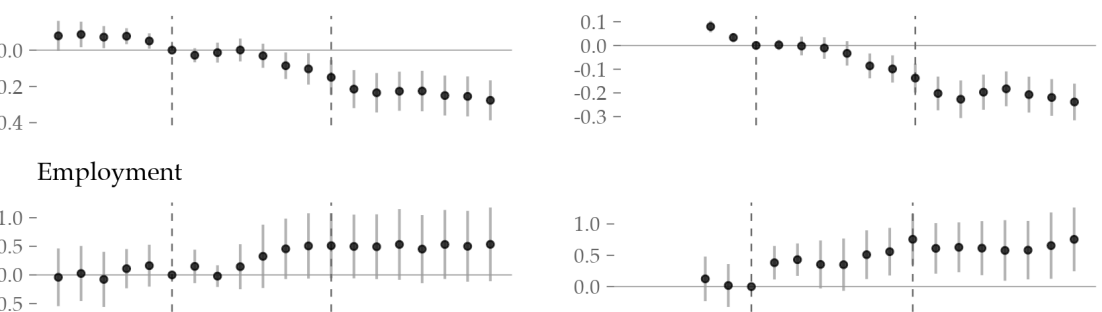

Num. Plants
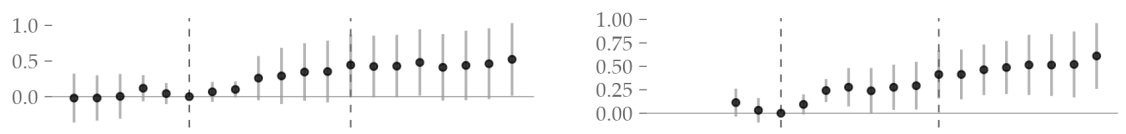

Output Share
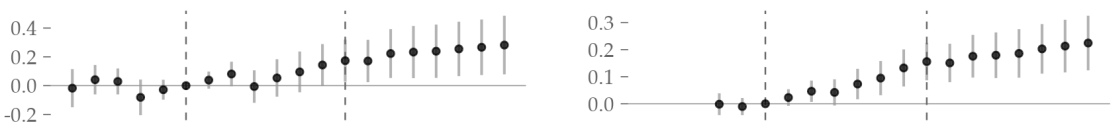

Labor Share
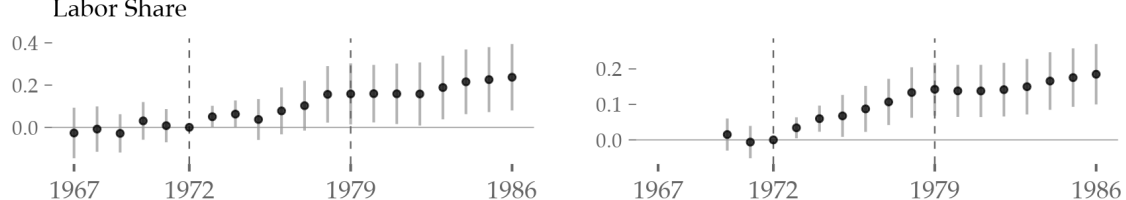

Panel B - Trade Developmet RCA (Balassa)

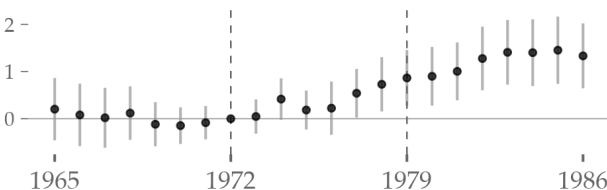

RCA (ihs)

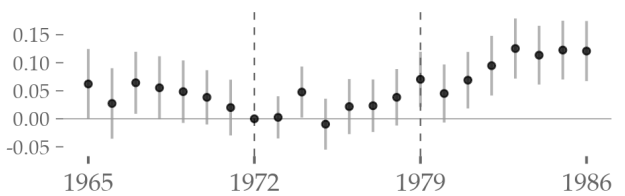

Relative Productivity (CDK)

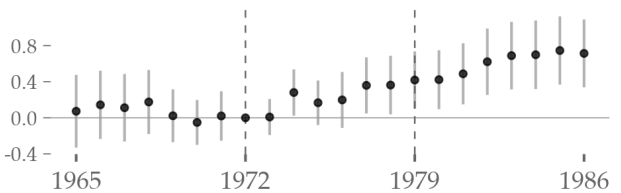

Prob. of Comparative Advantage (RCA $>1)$

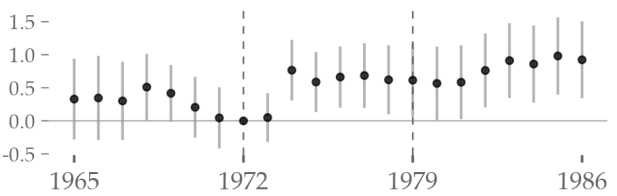

Export Share of Mfg. (ihs)

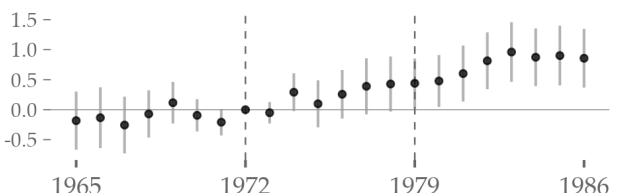

Note: Figure shows dynamic differences-in-differences estimates for the relationship between HCI and industrial development outcomes (Panel A) and trade development outcomes (Panel B). All figures plot DD regression coefficients. For Panel A, Left are estimates from long panel data. Right are estimates from detailed short panel data. Shipments are the real value of output shipped. Employment is the number of workers. Labor productivity is real value added by total employment. Output (labor) share is total manufacturing share of industry output (employment). Prices are industry output prices. Num. Plants are the number of establishments operating in an industry. For Panel B: Trade data (SITC) covers the 1965-1986 period. Top row corresponds to estimates of relative (export) productivity, as measured by CDK (see text). Middle row corresponds to regression estimates for conventional RCA index, IHS normalized. Bottom outcome, I[RCA>1], is probability of having realized comparative advantage, where the outcome dummy takes on the value of one for RCA $>1$, zero otherwise. Figure plots coefficients of interest from intereaction of interest: HCI x Year. Estimates are relative to 1972, the year before the $\mathrm{HCI}$ policy intervention. The line at 1972 is the start of the policy. The line at 1979 demarcates the fall of the Park regime. Standard errors are clustered at the industry-level and corrected for heteroskedasticity. Confidence bands are in light grey and correspond to 95 percent confidence intervals. 
Figure 5: Triple Difference Estimations of Korean HCI on Trade Development

Relative Productivity (CDK)

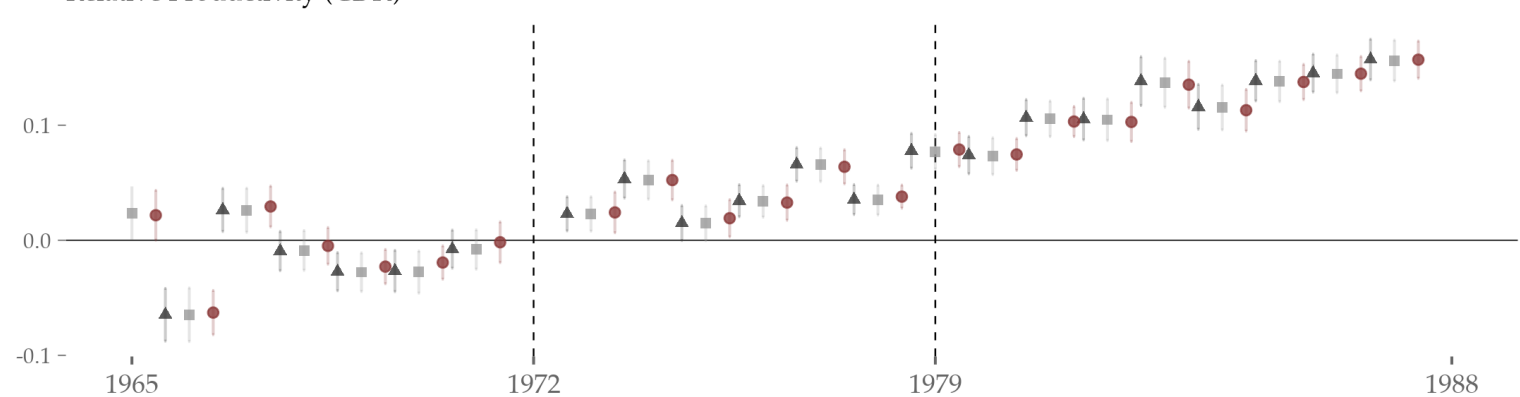

RCA (ihs)

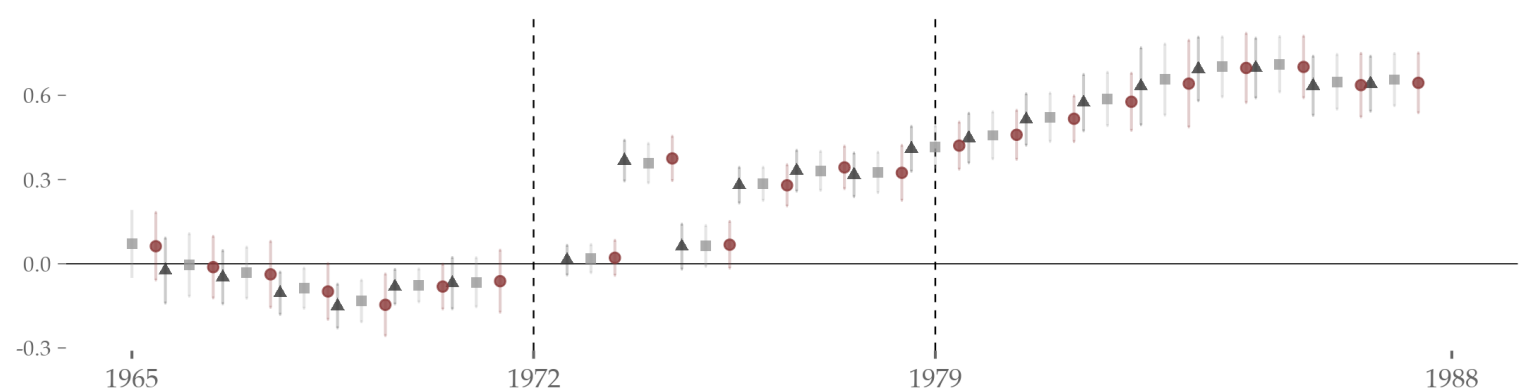

\section{Fixed Effects}

- Industry-Year, Country-Year

- Industry-Year, Country

- Industry, Year, and Country

Prob. of Comparative Advantage (Dummy)

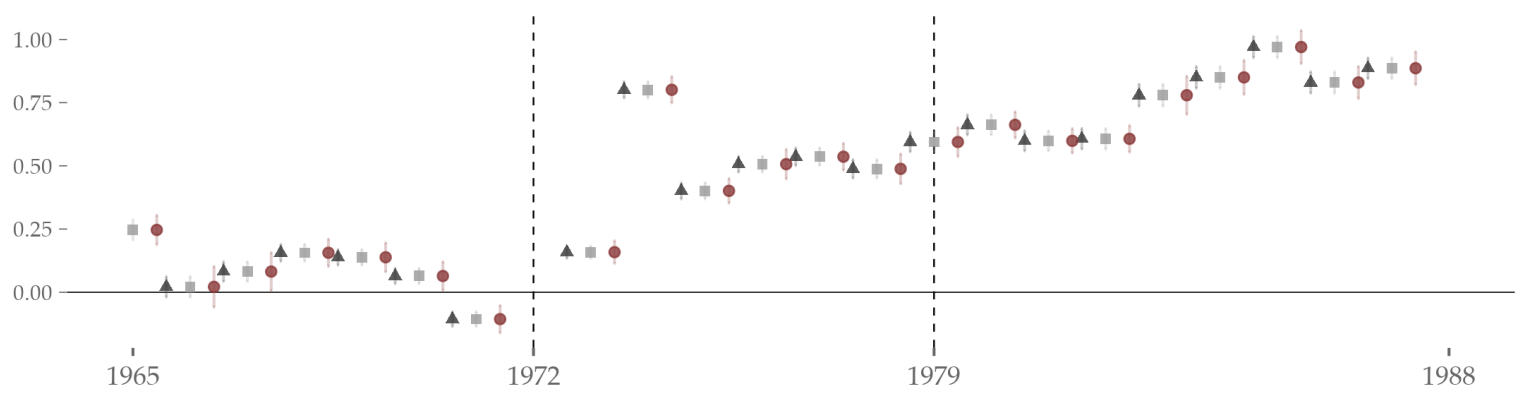

Note: Figure shows dynamic triple difference (DDD). for the main triple interaction coefficient. Figure plots triple difference interactions for the impact of (Korean) HCI on SITC-level trade data. Fixed effects for each specification are shown in the legend. Specifications are estimated using PPML estimation method, given the extent of zeros. All specifications use two-way clustering at the country and industry level. Figure plots coefficients of interest from intereaction of interest: HCI x Year x Korea. Estimates are relative to 1972, the year before the HCI policy intervention. The line at 1973 is the start of the policy. The line at 1979 demarcates the fall of the Park regime. Standard errors are clustered at the industry-level and corrected for heteroskedasticity. Confidence bands are in light grey and correspond to 95 percent confidence intervals. 
Figure 6: Average Investment Incentive and Trade Policy Outcomes 1967-1986
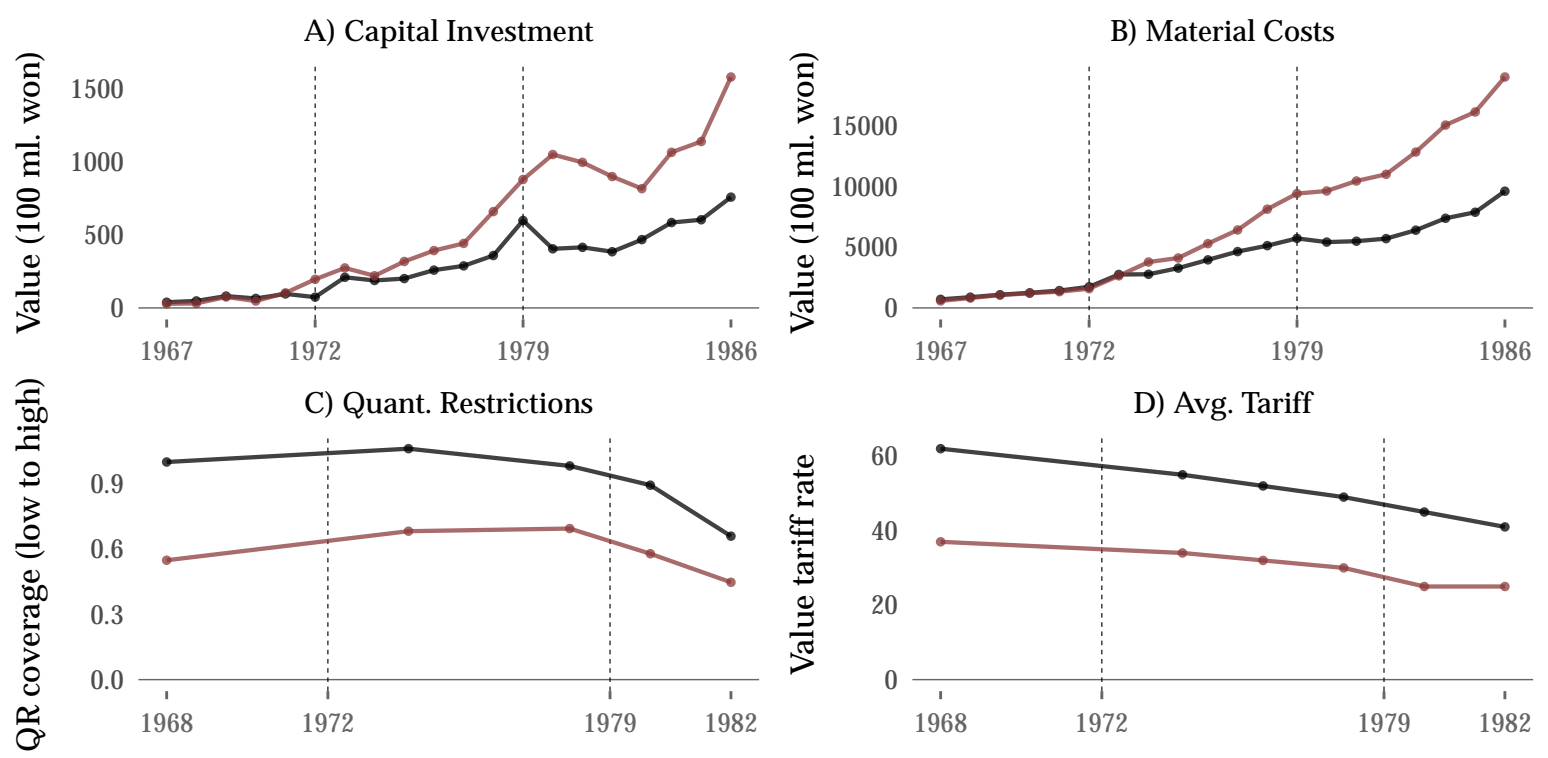

$$
\begin{aligned}
& \rightarrow \text { Non-HCI } \\
& \rightarrow \mathrm{HCI}
\end{aligned}
$$

Notes: Each panel plots outcomes related to investment and protection. Points are averages across $\mathrm{HCI}$ and non-HCI industries. The top row, panels A-C, are outcomes related to investment incentives. Panel A reports mean, real total capital formation across HCI and nonHCI industries. Panel B shows real total material costs. Panels C and D show outcomes for trade policy: D shows quantitative restriction measures $(\mathrm{QR})$ and $\mathrm{C}$ reports average ad valorem tariff rates (percent). QR is qualitative ranking of coverage on products within an industry, 0 being minimal coverage and 3 being high coverage. See discussion in text. Note that the average materials costs in an industry can indeed exceed investment: for the chemical industry in 1976 the nominal materials costs $(1,939,000$ thousand won) swamped investment costs (123,000,000 thousand Won) in the MMS. 
Figure 7: Input Use and Investment During HCI Drive, HCI v. Non-HCI Industries
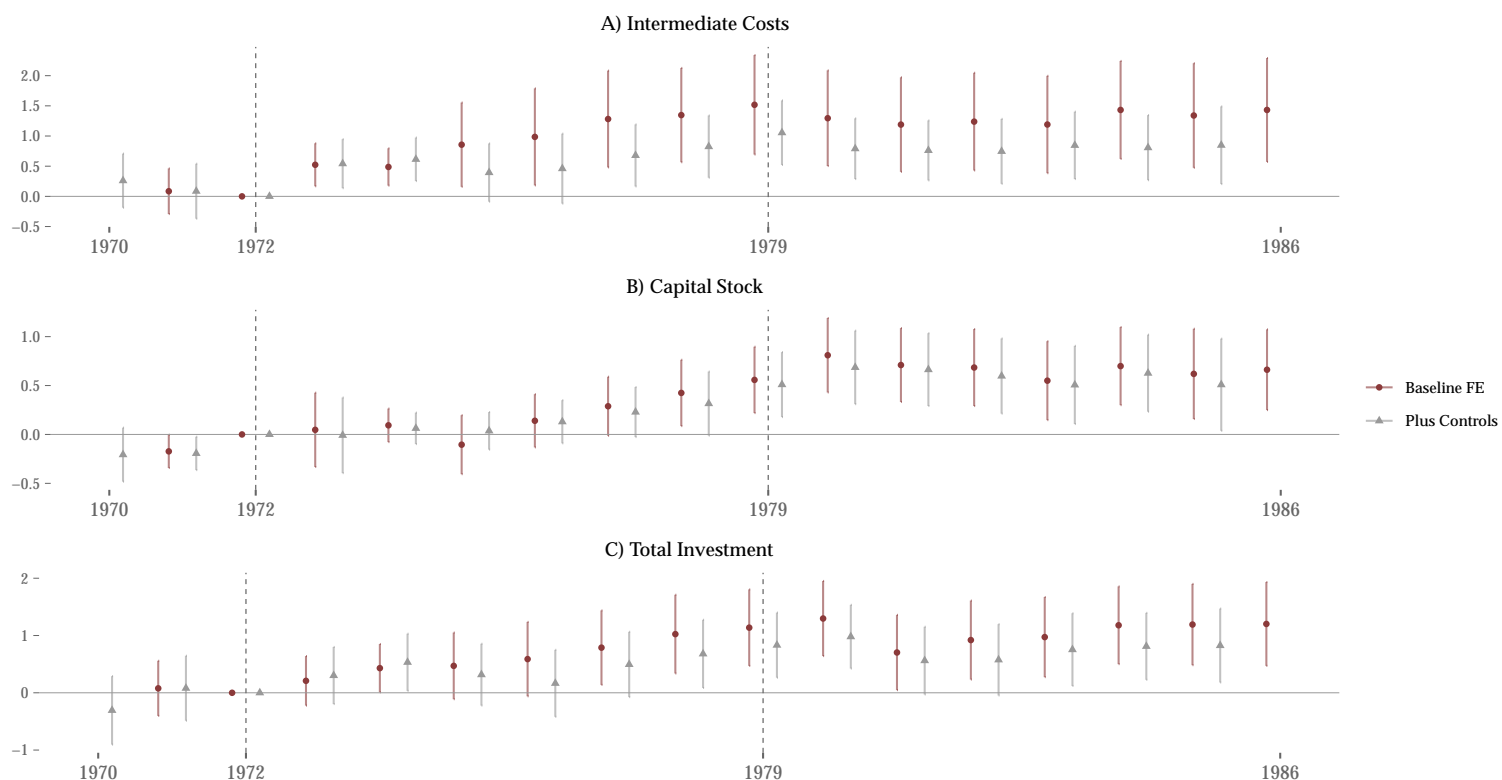

Note: Figure shows dynamic differences-in-differences estimates for the relationship between HCI and responses to investment incentives. Outcome are real total input material costs, total fixed capital stock, total capital formation. Panels report estimates from 5-digit industry panel (1970-1986). Controls include (pre-treatment) costs, avg. wages, avg. plant size, and labor productivity, interacted with time effects. Regression tables in Appendix. Figure plots coefficients of interest from intereaction of interest: HCI x Year. Estimates are relative to 1972, the year before the HCI policy intervention. The line at 1972 is the start of the policy. The line at 1979 demarcates the fall of the Park regime. Standard errors are clustered at the industry-level and corrected for heteroskedasticity. Confidence bands are in light grey and correspond to 95 percent confidence intervals.

Figure 8: Direct Forward Linkages and Downstream Value Added and Output Prices
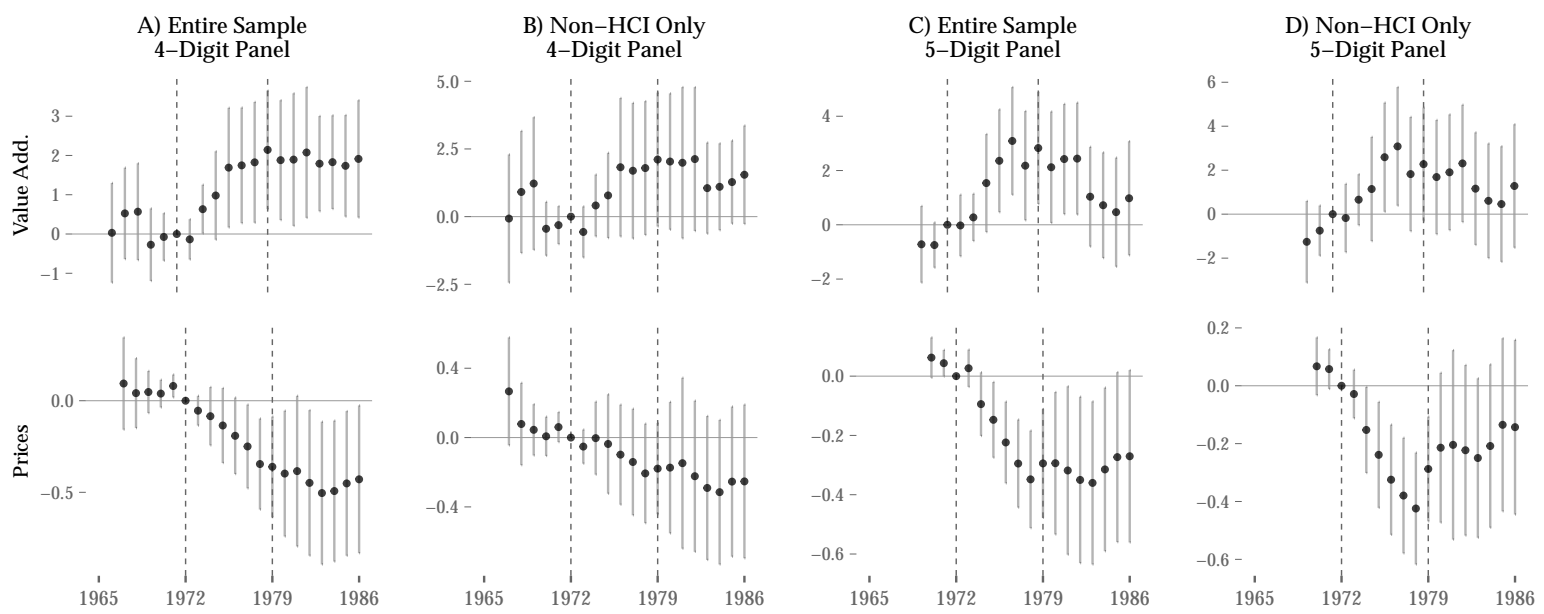

Notes: Figures plot dynamic differences-in-differences estimates for the relationship between direct forward linkage exposure to $\mathrm{HCI}$ and outcomes: real output (value shipped) (top) and value added per worker (bottom). Forward linkage measures corresponds to 1970 share of inputs sourced directly from HCI industry. See text for details. Estimates are relative to 1972, the year before HCI. The year 1979 corresponds to collapse of Park regime. Years are on the x-axis. Estimates for the effect of direct forward linkages effects (Linkage X Year) are on the yaxis. Linkage exposure is calculated from weighted sum of exposure through IO network; see text for details. Panels (A) and (C) show estimates for the entire sample of industries, controlling the effect of direct targeting, HCI x Year. Panels (B) and (D) shows estimates for only nontargeted industry. Regressions include controls for direct backward linkage connections, interacted with time. 95 percent confidence intervals are shown in gray. 
Figure 9: Direct Forward Linkages and the Evolution of Downstream Exports
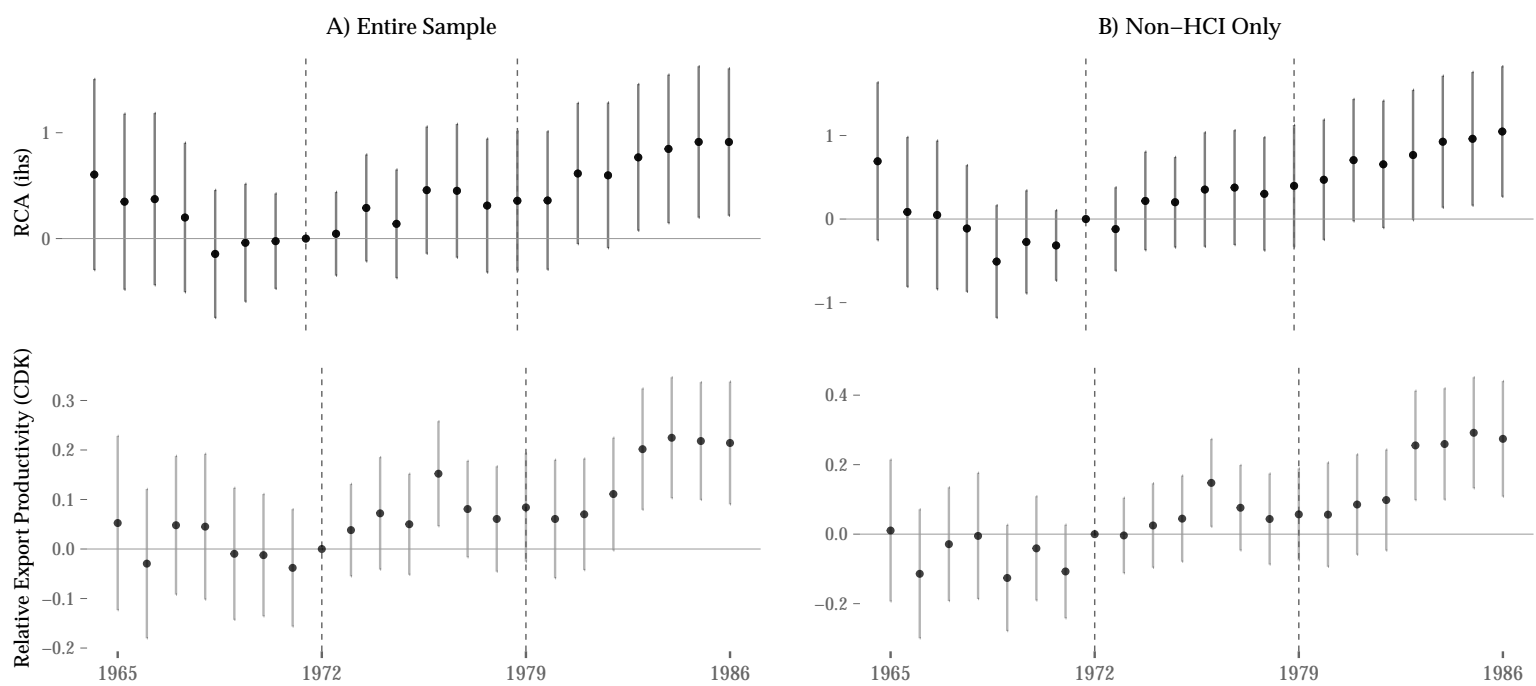

Notes: Figure plots dynamic differences-in-differences estimates for the relationship between direct forward linkage exposure to HCI and outcomes: revealed comparative advantage (RCA). Top row is RCA (ihs). The bottom row is the relative export productivity (CDK). Estimates are relative to, 1972, the year before HCI. The year 1979 corresponds to collapse of Park regime. Years are on the $x$-axis. Estimates for the effect of direct forward (Linkage X Year) linkages are on y-axis. Full sample regressions control for the main HCI x Year effect. All regressions include controls for direct backward linkage connections, interacted with time. 95 percent confidence intervals are shown in gray. 
Figure 10: Mechanisms: Direct Forward Linkages and Input Use and Investment
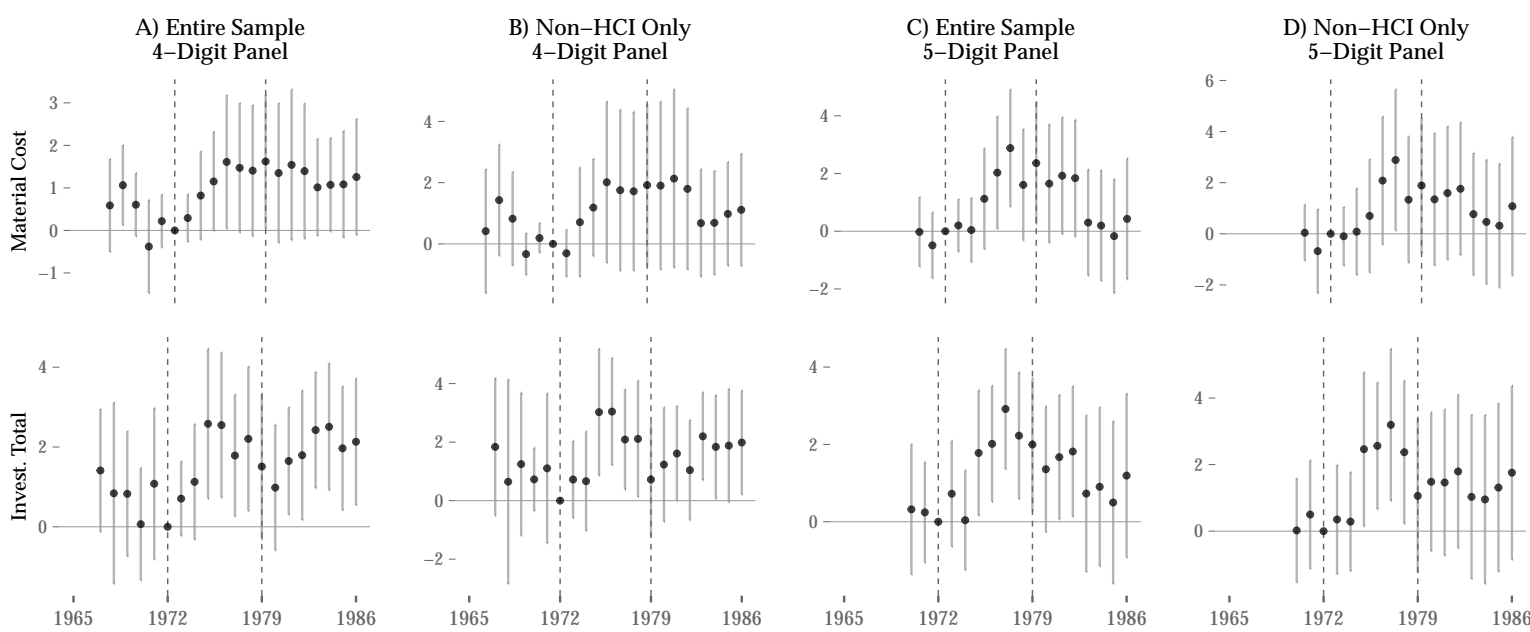

Notes: Figures plot dynamic differences-in-differences estimates for the relationship between direct forward linkage exposure to HCI and outcomes: real total variable input costs (Material Cost, ihs), and real total gross capital formation (ihs) (Invest. Total, ihs). Estimates are relative to 1972, the year before HCI. The year 1979 corresponds to collapse of Park regime. Years are on the x-axis. Estimates for the effect of direct forward linkages effects (Linkage X Year) are on the y-axis. Linkage exposure is calculated from weighted sum of exposure through IO network; see text for details. Panels (A) and (C) show estimates for the entire sample of industries, controlling the effect of direct targeting, HCI x Year. Panels (B) and (D) shows estimates for only non-targeted industry. Regressions include controls for direct backward linkage connections, interacted with time. 95 percent confidence intervals are shown in gray.

Table 1: Differences in Plant-Level TFP, HCI vs. Non-HCI Industry, 1980-1986

Type of TFP Estimate:

\begin{tabular}{|c|c|c|c|c|}
\hline Wooldridge & ACF & LP & OP & OLS \\
\hline 1 & 2 & 3 & 4 & 5 \\
\hline
\end{tabular}

Outcomes: Plant TFP

$\begin{array}{clllll}\text { Targeted } & 0.062^{* * *} & 0.033^{* * *} & 0.074^{* * *} & 0.058^{* * *} & 0.018^{*} \\ & (0.012) & (0.009) & (0.012) & (0.011) & (0.009) \\ \text { Industry X Year } & \text { Yes } & \text { Yes } & \text { Yes } & \text { Yes } & \text { Yes } \\ \text { R-Squared } & 0.458 & 0.335 & 0.474 & 0.347 & 0.159 \\ \text { Observations } & 272394 & 272394 & 272394 & 272394 & 272394\end{array}$

Note:

This table shows the relationship between plant-level TFP and HCI (Targeted industries) for the post-HCI period, 1980-1986. The specification regresses one of five TFP measures on a plant-level dummy indicator of HCI industry (see text for defitions). This equation controls and year-by-industry (4-digit level) effects. I use twoway clustering, where standard errors are clustered at the industry and plant level. Standard errors are clustered at the industry-level and corrected for heteroskedasticity. ${ }^{*}$ Significant at the 10 percent level. ${ }^{*}$ Significant at the 5 percent level. ** Significant at the 1 percent level.

* Mining and Manufacturing Survey and Mining and Manufacturing Census: 19801986. 
Table 2: Estimates for Average Impact (ATT) of HCI on Industrial Development Outcomes, Before and After 1973

\begin{tabular}{|c|c|c|c|c|}
\hline & \multicolumn{2}{|c|}{ Doubly-Robust DD Estimates } & \multicolumn{2}{|c|}{ Linear DD Estimates } \\
\hline & No Controls & With Controls & No Controls & With Controls \\
\hline & (1) & $(2)$ & (3) & $(4)$ \\
\hline \multicolumn{5}{|c|}{ Panel A) 5-Digit Panel 1970-1986 } \\
\hline \multirow[t]{2}{*}{ Val. Ship } & $1.1689^{* * *}$ & $0.9846^{* * *}$ & $1.1023^{* * *}$ & $0.8875^{* * *}$ \\
\hline & [0.3193] & {$[0.2123]$} & $(0.2971)$ & $(0.1681)$ \\
\hline \multirow[t]{2}{*}{ Employment } & $0.7458^{* * *}$ & $0.5678^{* * *}$ & $0.7286^{* * *}$ & $0.5037^{* * *}$ \\
\hline & [0.2423] & {$[0.1736]$} & $(0.2331)$ & $(0.132)$ \\
\hline \multirow[t]{2}{*}{ Prices } & $-0.181^{* * *}$ & $-0.1331^{* * *}$ & $-0.2181^{* * *}$ & $-0.1706^{* * *}$ \\
\hline & [0.032] & {$[0.0275]$} & $(0.033)$ & $(0.0281)$ \\
\hline \multirow[t]{2}{*}{ Labor Prod. } & $0.5854^{* *}$ & $0.4751^{* *}$ & $0.4747^{* *}$ & $0.32^{* *}$ \\
\hline & [0.2473] & [0.1857] & $(0.2241)$ & $(0.1245)$ \\
\hline \multirow[t]{2}{*}{ Output Share } & $0.1138^{* * *}$ & $0.136^{* * *}$ & $0.1214^{* * *}$ & $0.1354^{* * *}$ \\
\hline & {$[0.0286]$} & [0.0368] & $(0.0298)$ & $(0.0332)$ \\
\hline \multirow[t]{2}{*}{ Labor Share } & $0.1032^{* * *}$ & $0.1195^{* * *}$ & $0.1035^{* * *}$ & $0.1151^{* * *}$ \\
\hline & {$[0.0278]$} & {$[0.0326]$} & $(0.0287)$ & $(0.033)$ \\
\hline \multicolumn{5}{|c|}{ Panel B) 4-Digit Panel 1967-1986 } \\
\hline \multirow[t]{2}{*}{ Val. Ship } & $1.0381^{* * *}$ & $0.8691^{* *}$ & $1.0893^{* * *}$ & $0.8372^{* * *}$ \\
\hline & [0.313] & {$[0.3722]$} & $(0.3106)$ & $(0.303)$ \\
\hline \multirow[t]{2}{*}{ Employment } & $0.4789^{*}$ & $0.4789^{*}$ & $0.5066^{* *}$ & 0.3715 \\
\hline & [0.2579] & {$[0.2734]$} & $(0.2514)$ & $(0.2517)$ \\
\hline \multirow[t]{2}{*}{ Prices } & $-0.2055^{* * *}$ & $-0.1313^{* * *}$ & $-0.2849 * * *$ & $-0.2097^{* * *}$ \\
\hline & {$[0.0572]$} & {$[0.0441]$} & $(0.0666)$ & $(0.046)$ \\
\hline \multirow[t]{2}{*}{ Labor Prod. } & $0.6444^{* * *}$ & $0.5347^{* *}$ & $0.6163^{* * *}$ & $0.4597^{* *}$ \\
\hline & {$[0.2152]$} & {$[0.2286]$} & $(0.1979)$ & $(0.1884)$ \\
\hline \multirow[t]{2}{*}{ Output Share } & $0.2137^{* * *}$ & $0.1991^{*}$ & $0.2475^{* * *}$ & $0.1721^{* *}$ \\
\hline & {$[0.0748]$} & [0.1029] & $(0.0835)$ & $(0.0706)$ \\
\hline \multirow[t]{2}{*}{ Labor Share } & $0.1474^{* * *}$ & $0.1596^{* * *}$ & $0.1832^{* *}$ & $0.1461^{* *}$ \\
\hline & [0.0559] & {$[0.0604]$} & $(0.0718)$ & $(0.0658)$ \\
\hline \multirow[t]{2}{*}{ Export } & $1.6415^{* * *}$ & $1.2866^{* * *}$ & $1.767^{* * *}$ & $1.3957^{* * *}$ \\
\hline & [0.4321] & [0.3959] & $(0.5574)$ & $(0.4922)$ \\
\hline \multirow[t]{2}{*}{ Export Share } & $0.2507^{* * *}$ & $0.2511^{* *}$ & $0.3077^{* *}$ & $0.3099^{* *}$ \\
\hline & [0.0962] & [0.1011] & $(0.1224)$ & $(0.1265)$ \\
\hline
\end{tabular}

Note:

Table reports many estimates of the average treatment effect on the treated (ATT). Each cell is a single DID estimate the from doubly-robust (left column) estimator or similar linear two-way fixed effect estimator (right column). Targeted is industry-level dummy variable ( 0 or 1 ) for HCI sectors. Panel A shows estimates using shorter, detailed 5-digit level industrial data (1970-1986). Panel B shows estimates using longer, aggregate 4-digit level industrial data (1967-1986). Val. Ship is the real value of output shipped. Employment is the total number of workers. Prices are industry output indices. Labor Prod. is real value added per employee. Output Share is the manufacturing share of industry output. Exports are the real (won) value of exports and export share is the manufacturing share of industry exports. These are SITC trade data concorded to KSIC industry-level data (see text). Specifications without additional controls include baseline industry and year effects. Specifications with controls include pre-1973 averages for avg. wage, avg. size, cost, labor productivity. Bootstrapped standard errors are in square brackets (10,000 iterations) and are adjusted to allow for within-industry correlation. Cluster robust standard errors (industry-level) are reported in brackets. * Significant at the 10 percent level. ${ }^{* *}$ Significant at the 5 percent level. ${ }^{* *}$ Significant at the 1 percent level. 
Table 3: Estimates for Average Impact (ATT) of HCI on Export Development, Before and After 1973

\begin{tabular}{|c|c|c|c|c|}
\hline & \multicolumn{2}{|c|}{ Doubly-Robust DD Estimates } & \multicolumn{2}{|c|}{ Linear DD Estimates } \\
\hline & No Controls & With Controls & No Controls & With Controls \\
\hline & (1) & $(2)$ & (3) & $(4)$ \\
\hline \multicolumn{5}{|c|}{ 4-Digit SITC Data, 1965-1986 } \\
\hline \multirow[t]{2}{*}{ Rca (Classic) } & $0.4342^{* *}$ & $0.481^{* *}$ & $0.627^{*}$ & $0.915^{* * *}$ \\
\hline & {$[0.2168]$} & [0.2188] & $(0.3367)$ & $(0.2851)$ \\
\hline \multirow[t]{2}{*}{ Rca (IHS) } & $0.1041^{*}$ & $0.1301^{* *}$ & $0.4067^{* *}$ & $0.5676^{* * *}$ \\
\hline & [0.0532] & {$[0.0546]$} & $(0.1707)$ & $(0.1618)$ \\
\hline \multirow[t]{2}{*}{ Rca Cdk } & 0.0349 & 0.0103 & $0.0596^{* * *}$ & 0.0288 \\
\hline & [0.0243] & [0.0268] & $(0.0191)$ & $(0.0186)$ \\
\hline \multirow[t]{2}{*}{$\mathrm{I}[\mathrm{Rca}>1]$} & $0.0916^{* * *}$ & $0.1056^{* * *}$ & $0.5679^{* * *}$ & $0.6513^{* * *}$ \\
\hline & {$[0.0281]$} & {$[0.0304]$} & $(0.1827)$ & $(0.1963)$ \\
\hline \multirow[t]{2}{*}{ Export Share } & $0.0824^{* *}$ & $0.0715^{* *}$ & $0.9612^{* * *}$ & $0.9444^{* * *}$ \\
\hline & {$[0.0351]$} & [0.0364] & $(0.2896)$ & $(0.3106)$ \\
\hline \multirow[t]{2}{*}{ Export Share (IHS) } & $0.0646^{* * *}$ & $0.0599^{* * *}$ & $0.8053^{* * *}$ & $0.8293^{* * *}$ \\
\hline & [0.0192] & {$[0.021]$} & $(0.2287)$ & $(0.225)$ \\
\hline \multirow[t]{2}{*}{ Export Value } & . & . & $1.0418^{* * *}$ & $0.9207^{* * *}$ \\
\hline & . & . & $(0.2812)$ & $(0.3103)$ \\
\hline
\end{tabular}

Note:

Table reports many estimates of the average treatment effect on the treated (ATT). Each cell is a single DID estimate the from doubly-robust (left column) estimator or similar linear two-way fixed effect estimator (right column). Targeted is industry-level dummy variable (0 or 1) for HCI sectors. Panel is SITC Rev. 1 goods data over the period 19651986. RCA is the standard revealed comparative advantage index. RCA is also normalized using ihs. RCA (CDK) is relative productivity estimated using CDK; note CDK will be different because 0 s do not appear. Indicator I[RCA $>1]$ is dummy equal to one when RCA $>1,0$ otherwise Specifications without additional controls include baseline industry and year effects. Specifications with controls include pre-1973 averages for avg. wage, avg. size, cost, labor productivity. Bootstrapped standard errors are in square brackets (10,000 iterations) and are adjusted to allow for within-industry correlation. Cluster robust standard errors (industry-level) are reported in brackets. * Significant at the 10 percent level. ${ }^{* *}$ Significant at the 5 percent level. ${ }^{* * *}$ Significant at the 1 percent level. 
Table 4: Estimates for Average Impact (ATT) of HCI on Export Development, Before and After 1973

\begin{tabular}{|c|c|c|c|c|}
\hline & \multicolumn{2}{|c|}{ Semiparametric DID Estimates } & \multicolumn{2}{|c|}{ Linear DID Estimates } \\
\hline & No Controls & With Controls & No Controls & With Controls \\
\hline & $(1)$ & $(2)$ & (3) & $(4)$ \\
\hline \multicolumn{5}{|c|}{ Panel A) 5-Digit Panel 1970-1986 } \\
\hline \multirow[t]{2}{*}{ Material Cost } & $1.1511^{* * *}$ & $0.8747^{* * *}$ & $1.0462^{* * *}$ & $0.7386^{* * *}$ \\
\hline & {$[0.3234]$} & [0.2172] & $(0.297)$ & $(0.1694)$ \\
\hline \multirow[t]{2}{*}{ Invest. Total } & $0.9309^{* * *}$ & $0.8012^{* * *}$ & $0.908^{* * *}$ & $0.8146^{* * *}$ \\
\hline & {$[0.2605]$} & {$[0.2373]$} & $(0.2393)$ & $(0.2084)$ \\
\hline \multicolumn{5}{|c|}{ Panel B) 4-Digit Panel 1967-1986 } \\
\hline \multirow[t]{2}{*}{ Material Cost } & $0.8922^{* * *}$ & $1.1169^{* *}$ & $0.7748^{* * *}$ & $0.6815^{* *}$ \\
\hline & {$[0.3345]$} & {$[0.5323]$} & $(0.2931)$ & $(0.3086)$ \\
\hline \multirow[t]{2}{*}{ Invest. Total } & 0.2605 & 0.2733 & $0.452^{*}$ & $0.3847^{*}$ \\
\hline & {$[0.2838]$} & {$[0.2131]$} & $(0.2614)$ & $(0.2084)$ \\
\hline
\end{tabular}

Note:

Table reports many estimates of the average treatment effect on the treated (ATT). Each cell is a single DID estimate the from doubly-robust (left column) estimator or similar linear two-way fixed effect estimator (right column). Targeted is industry-level dummy variable (0 or 1 ) for HCI sectors. Panel A shows estimates using shorter, detailed 5-digit level industrial data (1970-1986). Panel B shows estimates using longer, aggregate 4-digit level industrial data (1967-1986). Material Cost is real input material costs. Invest. Total is real total gross capital formation. Specifications without additional controls include baseline industry and year effects. Specifications with controls include pre-1973 averages for avg. wage, avg. size, cost, labor productivity. Bootstrapped standard errors are in square brackets (10,000 iterations) and are adjusted to allow for within-industry correlation. Cluster robust standard errors (industry-level) are reported in brackets. * Significant at the 10 percent level. ${ }^{* *}$ Significant at the 5 percent level. ${ }^{* *}$ Significant at the 1 percent level. 
Table 5: Differences in Trade Policy, HCI vs. Non-HCI Industry, 1968-1982

\begin{tabular}{|c|c|c|c|c|c|c|c|c|c|c|c|c|}
\hline & \multicolumn{8}{|c|}{ Outcomes: Levels } & \multicolumn{4}{|c|}{ Outcomes: Differences } \\
\hline & \multicolumn{4}{|c|}{ Tariff Rate } & \multicolumn{4}{|c|}{ QRs Coverage } & \multicolumn{2}{|c|}{ Tariffs Rate } & \multicolumn{2}{|c|}{ QR Coverage } \\
\hline & 1 & 2 & 3 & 4 & 5 & 6 & 7 & 8 & 9 & 10 & 11 & 12 \\
\hline \multicolumn{13}{|c|}{ Panel A - Outcomes: Output Protection } \\
\hline \multirow[t]{2}{*}{ Targeted } & $-0.516^{* * *}$ & $-0.290^{*}$ & $-0.505^{* * *}$ & $-0.276^{*}$ & $-0.286^{* * *}$ & $-0.196^{* *}$ & $-0.268^{* * *}$ & $-0.188^{* *}$ & 0.035 & 0.047 & 0.029 & $0.083^{*}$ \\
\hline & $(0.104)$ & $(0.113)$ & $(0.103)$ & $(0.116)$ & $(0.076)$ & $(0.062)$ & $(0.076)$ & $(0.064)$ & $(0.029)$ & $(0.036)$ & $(0.017)$ & $(0.035)$ \\
\hline Year Effect & Yes & Yes & Yes & Yes & Yes & Yes & Yes & Yes & Yes & Yes & Yes & Yes \\
\hline Controls & Yes & Yes & Yes & Yes & Yes & Yes & Yes & Yes & Yes & Yes & Yes & Yes \\
\hline Sample & Full & Full & Post-1973 & Post-1973 & Full & Full & Post-1973 & Post-1973 & Full & Full & Full & Full \\
\hline Weighted & None & Weighted & None & Weighted & None & Weighted & None & Weighted & None & Weighted & None & Weighted \\
\hline R-Squared & 0.433 & 0.482 & 0.426 & 0.479 & 0.200 & 0.256 & 0.210 & 0.261 & 0.188 & 0.207 & 0.202 & 0.391 \\
\hline Observations & 516 & 516 & 430 & 430 & 430 & 430 & 344 & 344 & 258 & 258 & 430 & 430 \\
\hline Clusters & 86 & 86 & 86 & 86 & 86 & 86 & 86 & 86 & 86 & 86 & 86 & 86 \\
\hline \multicolumn{13}{|c|}{ Panel B - Outcomes: Exposure to Input Protection } \\
\hline \multirow[t]{2}{*}{ Targeted } & $-0.408^{* *}$ & $-0.418^{*}$ & $-0.445^{* *}$ & $-0.441^{* *}$ & $-0.119^{* * *}$ & $-0.111^{* * *}$ & $-0.121^{* * *}$ & $-0.112^{* * *}$ & $-0.047^{* *}$ & $-0.049^{* *}$ & -0.008 & -0.002 \\
\hline & $(0.128)$ & $(0.161)$ & $(0.132)$ & $(0.165)$ & $(0.030)$ & $(0.031)$ & $(0.028)$ & $(0.030)$ & $(0.017)$ & $(0.017)$ & $(0.012)$ & $(0.013)$ \\
\hline Year Effect & Yes & Yes & Yes & Yes & Yes & Yes & Yes & Yes & Yes & Yes & Yes & Yes \\
\hline Controls & Yes & Yes & Yes & Yes & Yes & Yes & Yes & Yes & Yes & Yes & Yes & Yes \\
\hline Sample & Full & Full & Post-1973 & Post-1973 & Full & Full & Post-1973 & Post-1973 & Full & Full & Full & Full \\
\hline Weighted & None & Weighted & None & Weighted & None & Weighted & None & Weighted & None & Weighted & None & Weighted \\
\hline R-Squared & 0.218 & 0.294 & 0.203 & 0.281 & 0.289 & 0.427 & 0.307 & 0.430 & 0.253 & 0.361 & 0.303 & 0.286 \\
\hline Observations & 516 & 516 & 430 & 430 & 430 & 430 & 344 & 344 & 430 & 430 & 258 & 258 \\
\hline Clusters & 86 & 86 & 86 & 86 & 86 & 86 & 86 & 86 & 86 & 86 & 86 & 86 \\
\hline
\end{tabular}

Note:
Table shows the relationship between trade policy and HCI (Targeted industries), using nominal trade policy data for the years 1968-1982. Columns show estimates in levels and differences (see text). All regressions are at the 4-digit KSIC industry level. The first set of columns report results for regressions in levels. The second set of columns reports differences outcomes. Columns (1-4) report estimates for tariffs. Columns 5-8 reports estimates for quantitative restriction coverage (QR). Columns (9-10) shows estimates for changes in tariff rates. Columns (11-12) shows estimates for changes in tariff rates QRs. Standard errors are clustered at the industry-level and corrected for heteroskedasticity. ${ }^{*}$ Significant at the 10 percent level. ${ }^{* *}$ Significant at the 5 percent level. ${ }^{* * *}$ Significant at the 1 percent level.

a Panel A groups estimates for tariff and QR outcomes related to industry-level output market protection-the average level (or change) in tariff or QR coverage of a given output market. Panel B examines the industry-level exposure to tariffs vis-a-vis their input bundle. Input exposure is calculated using the weighted sum of QRs or tariffs for industry's input basket, with weights are taken from the 1970 input-output accounts. Sample refers to whether all five periods are used, or whether only post-HCI (1973) observations are used.

* Source - Tariffs rates and QR coverages, Luedde-Neurath (1986). Mining and Manufacturing Census: 1967-1986. 
Table 6: Mechanisms - Relationship Between Industry-Level Experience and Industry Outcomes, HCI v. Non-HCI Industry, Following HCI Announcement, Post-1972

\begin{tabular}{|c|c|c|c|c|c|c|c|c|c|c|}
\hline & Prices & Prices & Lab Prod & Lab Prod & TFP (OP) & $\mathrm{TFP}(\mathrm{OP})$ & TFP (ACF) & TFP (ACF) & RCA (CDK) & RCA (ihs) \\
\hline & 1 & 2 & 3 & 4 & 5 & 6 & 7 & 8 & 9 & 10 \\
\hline \multicolumn{11}{|c|}{ Panel A - Learning in HCI-Only Sample } \\
\hline Experience & $-0.114^{* * *}$ & $-0.130^{* * *}$ & $0.279^{* * *}$ & $0.248^{* * *}$ & 0.081 & $0.175^{\text {****}}$ & 0.120 & $0.246^{* * *}$ & & \\
\hline Avg. Size & $\begin{array}{l}(0.027) \\
0.068^{*}\end{array}$ & $\begin{array}{l}(0.030) \\
0.091^{* *}\end{array}$ & $\begin{array}{l}(0.040) \\
-0.433^{* * *}\end{array}$ & $\begin{array}{l}(0.037)^{* * *} \\
-0.270^{* * *}\end{array}$ & $\begin{array}{l}(0.050) \\
-0.325^{* * *}\end{array}$ & $\begin{array}{l}(0.036) \\
-0.248^{* * *}\end{array}$ & $\begin{array}{l}(0.062) \\
-0.259 * * *\end{array}$ & $\begin{array}{l}(0.034) \\
-0.197 * * *\end{array}$ & -0.052 & $-0,545^{* *}$ \\
\hline & $(0.029)$ & $(0.034)$ & $(0.052)$ & $(0.053)$ & $(0.066)$ & $(0.058)$ & $(0.071)$ & $\begin{array}{l}-0.197 \\
(0.054)\end{array}$ & $\begin{array}{l}-0.052 \\
(0.039)\end{array}$ & $(0.184)$ \\
\hline Capital Per Worker & & $\begin{array}{l}0.009 \\
(0.014)\end{array}$ & & $\begin{array}{l}0.007 \\
(0.022)\end{array}$ & & $\begin{array}{l}-0.225^{* * *} \\
(0.025)\end{array}$ & & $\begin{array}{l}-0.288^{* * *} \\
(0.029)\end{array}$ & & \\
\hline Materials Per Worker & & $\begin{array}{l}0.078^{* * *} \\
(0.028)\end{array}$ & & $0.370^{* * *}$ & & $0.373^{* * *}$ & & $0.393^{* * *}$ & -0.019 & -0.021 \\
\hline Invest. Per Worker & & $\begin{array}{l}(0.028) \\
-0.013^{*}\end{array}$ & & $\begin{array}{l}(0.043) \\
0.042^{* * *}\end{array}$ & & $\begin{array}{l}(0.046) \\
0.043^{* *}\end{array}$ & & $\begin{array}{l}(0.044) \\
0.047^{* * *}\end{array}$ & $\begin{array}{l}(0.020) \\
-0.000\end{array}$ & $\begin{array}{l}(0.085) \\
-0.042\end{array}$ \\
\hline & & $(0.005)$ & & $(0.012)$ & & $(0.013)$ & & $(0.012)$ & $(0.008)$ & $\begin{array}{l}-0.042 \\
(0.029)\end{array}$ \\
\hline Experience (Export) & & & & & & & & & 0.024 & $0.412^{* * *}$ \\
\hline Industry Effect & Yes & Yes & Yes & Yes & Yes & Yes & Yes & Yes & $\begin{array}{l}(0.014) \\
\text { Yes }\end{array}$ & $\begin{array}{l}(0.097) \\
\text { Yes }\end{array}$ \\
\hline Year Effect & Yes & Yes & Yes & Yes & Yes & Yes & Yes & Yes & Yes & Yes \\
\hline R-Squared & 0.972 & 0.973 & 0.934 & 0.945 & 0.967 & 0.976 & 0.928 & 0.954 & 0.764 & 0.815 \\
\hline Observations & 1325 & 1316 & 1325 & 1316 & 1316 & 1316 & 1316 & 1316 & 450 & 454 \\
\hline Clusters & 101 & 100 & 101 & 100 & 100 & 100 & 100 & 100 & 33 & 33 \\
\hline \multicolumn{11}{|c|}{ Panel B - Learning in HCI vs. Non-HCI } \\
\hline Experience & $-0.052^{\text {** }}$ & $-0.063^{* *}$ & $0.210^{* * *}$ & $0.162^{* *}$ & -0.028 & $0.119^{*}$ & 0.073 & $0.180^{* * *}$ & & \\
\hline Hci X Experience & $\begin{array}{l}(0.019) \\
-0.098^{* * *}\end{array}$ & $\begin{array}{l}(0.020) \\
-0.100^{* * *}\end{array}$ & $\begin{array}{l}(0.059) \\
0.115^{* *}\end{array}$ & $\begin{array}{l}(0.050) \\
0.103^{* * *}\end{array}$ & $\begin{array}{l}(0.066) \\
0.150^{* * *}\end{array}$ & $\begin{array}{l}(0.049) \\
0.139^{* * *}\end{array}$ & $\begin{array}{l}(0.062) \\
0.077^{*}\end{array}$ & $\begin{array}{l}(0.046) \\
0.064^{*}\end{array}$ & & \\
\hline & $(0.016)$ & $(0.016)$ & $(0.035)$ & $(0.030)$ & $(0.039)$ & $(0.032)$ & $(0.036)$ & $(0.028)$ & & \\
\hline Avg. Size & $0.059^{*}$ & $0.063^{* *}$ & $-0.352^{* * * *}$ & $-0.205^{* * * *}$ & $-0.228^{* * *}$ & $-0.165^{* * *}$ & $-0.218^{* * *}$ & $-0.130^{* *}$ & $-0.037^{*}$ & $-0.328^{* * *}$ \\
\hline & $(0.023)$ & $(0.024)$ & $(0.053)$ & $(0.043)$ & $(0.063)$ & $(0.046)$ & $(0.055)$ & $(0.044)$ & $(0.018)$ & $(0.084)$ \\
\hline Capital Per Worker & & $\begin{array}{l}0.007 \\
(0.010)\end{array}$ & & $\begin{array}{l}-0.019 \\
(0.021)\end{array}$ & & $\begin{array}{l}-0.321^{* * *} \\
(0.038)\end{array}$ & & $\begin{array}{l}-0.259^{* * *} \\
(0.025)\end{array}$ & & \\
\hline Materials Per Worker & & 0.031 & & $0.458^{* * *}$ & & $0.449^{* * *}$ & & $0.467^{* * *}$ & -0.003 & 0.002 \\
\hline Invest. Per Worker & & $\begin{array}{l}(0.017) \\
-0.014^{* * *}\end{array}$ & & $\begin{array}{l}(0.032) \\
0.030^{* *}\end{array}$ & & $\begin{array}{l}(0.033) \\
0.038^{* * *}\end{array}$ & & $\begin{array}{l}(0.033) \\
0.043^{* * *}\end{array}$ & $\begin{array}{l}(0.010) \\
0.001\end{array}$ & $\begin{array}{l}(0.048) \\
-0.017\end{array}$ \\
\hline & & $\begin{array}{l}-0.014 \\
(0.004)\end{array}$ & & $(0.010)$ & & $(0.011)$ & & $(0.011)$ & $(0.004)$ & $(0.016)$ \\
\hline Experience (Export) & & & & & & & & & -0.011 & $0.130^{* *}$ \\
\hline \multirow{2}{*}{\multicolumn{9}{|c|}{ Hci X Experience (Export) }} & $\begin{array}{l}(0.007) \\
0.044^{* * *}\end{array}$ & $\begin{array}{l}(0.048) \\
0.241^{* * *}\end{array}$ \\
\hline & & & & & & & & & $(0.010)$ & $(0.061)$ \\
\hline Industry Effect & Yes & Yes & Yes & Yes & Yes & Yes & Yes & Yes & Yes & Yes \\
\hline Year Effect & Yes & Yes & Yes & Yes & Yes & Yes & Yes & Yes & Yes & Yes \\
\hline R-Squared & 0.951 & 0.951 & 0.857 & 0.888 & 0.931 & 0.953 & 0.896 & 0.928 & 0.857 & 0.895 \\
\hline Observations & 3594 & 3581 & 3595 & 3582 & 3582 & 3582 & 3582 & 3582 & 1167 & 1191 \\
\hline Clusters & 275 & 274 & 275 & 274 & 274 & 274 & 274 & 274 & 86 & 87 \\
\hline $\begin{array}{l}\text { Linear Combination } \\
\text { St.err. }\end{array}$ & $\begin{array}{l}-0.151 \\
(0.021)\end{array}$ & $\begin{array}{l}-0.163 \\
(0.022)\end{array}$ & $\begin{array}{l}0.324 \\
(0.042)\end{array}$ & $\begin{array}{l}0.266 \\
(0.038)\end{array}$ & $\begin{array}{l}0.122 \\
(0.049)\end{array}$ & $\begin{array}{l}0.258 \\
(0.042)\end{array}$ & $\begin{array}{l}0.149 \\
(0.052)\end{array}$ & $\begin{array}{l}0.245 \\
(0.039)\end{array}$ & $\begin{array}{l}0.033 \\
(0.011)\end{array}$ & $\begin{array}{l}0.371 \\
(0.068)\end{array}$ \\
\hline
\end{tabular}

Note:

Table shows the industry-level relationship between industrial outcomes and experience (cumulative output per worker), in $\mathrm{HCI}$ v. non-HCI industry. Specifically, I consider the role of experience on outcomes related to productivity and comparative advantage: prices, labor productivity (the reciprocal of unit labor cost), TFP (OP and ACF), and RCA (CDK and classic index, ihs adjusted). Panel A shows learning in only the HCI industry subsample. Panel B is for the full sample. For Panel B, the combined effect of the coefficients (Linear Combination), Experience and Experience $x$ $\mathrm{HCI}$, is shown at the bottom of the table. All industrial outcome regressions estimated using the detailed 5-digit panel (1970-1986). RCA regressions use 4-digit SITC trade data and export experience measured from value exported. Standard errors are clustered at the industry-level and corrected for heteroskedasticity. ${ }^{*}$ Significant at the 10 percent level. ${ }^{* *}$ Significant at the 5 percent level. *** Significant at the 1 percent level.

* Source - Mining and Manufacturing Survey and Mining and Manufacturing Census: 1970-1986. 
Table 7: Mechanisms - Relationship Between Plant-Level and Industry-Level Learning, HCI v. NonHCI, 1980-1986

\begin{tabular}{|c|c|c|c|c|c|}
\hline & \multicolumn{5}{|c|}{ Outcome: TFP } \\
\hline & 1 & 2 & 3 & 4 & 5 \\
\hline \multirow[t]{2}{*}{ Experience } & $0.356^{* * *}$ & $0.342^{* * *}$ & $0.352^{* * *}$ & $0.351^{* * *}$ & $0.360^{* * *}$ \\
\hline & $(0.013)$ & $(0.012)$ & $(0.015)$ & $(0.015)$ & $(0.014)$ \\
\hline \multirow[t]{2}{*}{ Hci X Experience } & $0.062^{* * *}$ & $0.037^{* *}$ & $0.037^{* *}$ & $0.037^{* *}$ & $0.034^{*}$ \\
\hline & $(0.014)$ & $(0.014)$ & $(0.014)$ & $(0.014)$ & $(0.014)$ \\
\hline \multirow[t]{2}{*}{ Experience (Industry) } & & $0.039^{* * *}$ & $0.039^{* * *}$ & $0.039^{* * *}$ & $0.037^{* *}$ \\
\hline & & $(0.012)$ & $(0.012)$ & $(0.012)$ & $(0.011)$ \\
\hline \multirow[t]{2}{*}{ Hci X Experience (Industry) } & & $0.129^{* * *}$ & $0.129^{* * *}$ & $0.129^{* * *}$ & $0.126^{* * *}$ \\
\hline & & $(0.020)$ & $(0.020)$ & $(0.020)$ & $(0.020)$ \\
\hline \multirow[t]{2}{*}{ Capital Per Worker } & & & -0.008 & -0.008 & $-0.024^{* * *}$ \\
\hline & & & $(0.005)$ & $(0.005)$ & $(0.005)$ \\
\hline \multirow[t]{2}{*}{ Materials Per Worker } & & & -0.012 & -0.012 & $-0.029^{*}$ \\
\hline & & & $(0.014)$ & $(0.014)$ & $(0.013)$ \\
\hline \multirow[t]{2}{*}{ Skill Ratio } & & & & -0.050 & -0.035 \\
\hline & & & & $(0.052)$ & $(0.051)$ \\
\hline \multirow[t]{2}{*}{ Invest. Per Worker } & & & & & $0.236^{* * *}$ \\
\hline & & & & & $(0.011)$ \\
\hline Plant Effect & Yes & Yes & Yes & Yes & Yes \\
\hline Year Effect & Yes & Yes & Yes & Yes & Yes \\
\hline R-Squared & 0.633 & 0.638 & 0.638 & 0.638 & 0.642 \\
\hline Observations & 237334 & 237334 & 237334 & 237334 & 237334 \\
\hline Clusters (Industry And Plant) & $490 \times 58245$ & $490 \times 58245$ & $490 \times 58245$ & $490 \times 58245$ & $490 \times 58245$ \\
\hline \multirow[t]{2}{*}{ Linear Combination (Firm-Level) } & 0.418 & 0.379 & 0.390 & 0.388 & 0.395 \\
\hline & $(0.015)$ & $(0.014)$ & $(0.017)$ & $(0.017)$ & $(0.017)$ \\
\hline \multirow[t]{2}{*}{ Linear Combination (Industry-Level) } & & 0.168 & 0.168 & 0.168 & 0.163 \\
\hline & & $(0.018)$ & $(0.018)$ & $(0.018)$ & $(0.018)$ \\
\hline
\end{tabular}

Note:

Table shows the plant-level relationship between TFP (ACF) and measures of experience (cumulative output per worker). 'Experience' is plant-level cumulative learning and 'Experience (Industry)' are industry-level spillovers. The combined effect of the experience coefficients are shown at the bottom of the table (Linear Combination). Specifications are estimated using industry and year effects. Standard errors are clustered at the industry-level and corrected for heteroskedasticity. * Significant at the 10 percent level. ** Significant at the 5 percent level. ${ }^{* *}$ Significant at the 1 percent level.

* Source - Mining and Manufacturing Survey and Mining and Manufacturing Census, 1980-1986 
Table 8: Average Impact of Linkages on Output, Before and After 1973

\begin{tabular}{|c|c|c|c|c|c|c|c|c|}
\hline & \multicolumn{8}{|c|}{ Outcome - Real value added (ihs) } \\
\hline & \multicolumn{4}{|c|}{ Panel A) 5-Digit Panel, 1970 - 1986} & \multicolumn{4}{|c|}{ Panel B) 4-Digit Panel, 1967 - 1986} \\
\hline & \multicolumn{2}{|c|}{ Full Sample } & \multicolumn{2}{|c|}{ Non-HCI Sample } & \multicolumn{2}{|c|}{ Full Sample } & \multicolumn{2}{|c|}{ Non-HCI Sample } \\
\hline & 1 & 2 & 3 & 4 & 1 & 2 & 3 & 4 \\
\hline \multirow[t]{2}{*}{ Post $X$ Forward Link } & $1.920^{* *}$ & $2.090^{* *}$ & 1.997 & $2.155^{*}$ & 1.084 & $1.442^{*}$ & 0.886 & 1.153 \\
\hline & $(0.698)$ & $(0.774)$ & $(1.020)$ & $(1.074)$ & $(0.683)$ & $(0.610)$ & $(1.053)$ & $(0.937)$ \\
\hline \multirow[t]{2}{*}{ Post X Backward Link } & $-1.664^{*}$ & $-1.593^{*}$ & $-1.962^{*}$ & $-1.814^{*}$ & -1.119 & -1.120 & $-2.081^{* *}$ & $-2.144^{* *}$ \\
\hline & $(0.685)$ & $(0.685)$ & $(0.890)$ & $(0.883)$ & $(0.641)$ & $(0.677)$ & $(0.693)$ & $(0.724)$ \\
\hline Industry Fe & Yes & Yes & Yes & Yes & Yes & Yes & Yes & Yes \\
\hline Year Fe & Yes & Yes & Yes & Yes & Yes & Yes & Yes & Yes \\
\hline Targeted X Year & Yes & Yes & No & No & Yes & Yes & No & No \\
\hline Network Controls & No & Yes & No & Yes & No & Yes & No & Yes \\
\hline R-Squared & 0.766 & 0.767 & 0.753 & 0.756 & 0.836 & 0.839 & 0.806 & 0.811 \\
\hline Observations & 4726 & 4726 & 2992 & 2992 & 1760 & 1760 & 1100 & 1100 \\
\hline Clusters & 278 & 278 & 176 & 176 & 88 & 88 & 55 & 55 \\
\hline
\end{tabular}

Note:

Average differences-in-differences estimates, before and after 1973. Regressions interact linkage measure with Post indicator. For these estimates, both linkage interactions are shown (forward and backward); whereas, dynamic estimates presented only linkages for the interaction of interest (forward or backward). Standard errors are clustered at the industry-level and corrected for heteroskedasticity. * Significant at the 10 percent level. ${ }^{* *}$ Significant at the 5 percent level. *** Significant at the 1 percent level.

* Source for Panel A - Mining and Manufacturing Survey and Mining and Manufacturing Census: 1970-1986.

${ }^{\dagger}$ Source for Panel B - Mining and Manufacturing Survey and Mining and Manufacturing Census: 1967-1986.

Table 9: Average Impact of Linkages on Output Prices, Before and After 1973

\begin{tabular}{|c|c|c|c|c|c|c|c|c|}
\hline & \multicolumn{8}{|c|}{ Outcome - Output prices (ihs) } \\
\hline & \multicolumn{4}{|c|}{ Panel A) 5-Digit Panel, 1970 - 1986} & \multicolumn{4}{|c|}{ Panel B) 4-Digit Panel, 1967 - 1986} \\
\hline & \multicolumn{2}{|c|}{ Full Sample } & \multicolumn{2}{|c|}{ Non-HCI Sample } & \multicolumn{2}{|c|}{ Full Sample } & \multicolumn{2}{|c|}{ Non-HCI Sample } \\
\hline & 1 & 2 & 3 & 4 & 1 & 2 & 3 & 4 \\
\hline \multirow[t]{2}{*}{ Post $X$ Forward Link } & $-0.218^{*}$ & $-0.289^{* *}$ & -0.192 & $-0.271 * *$ & $-0.281^{*}$ & $-0.372^{* *}$ & -0.161 & -0.246 \\
\hline & $(0.0984)$ & $(0.0964)$ & $(0.108)$ & $(0.102)$ & $(0.141)$ & $(0.140)$ & $(0.151)$ & $(0.142)$ \\
\hline \multirow[t]{2}{*}{ Post X Backward Link } & $0.339^{* * *}$ & $0.317^{* * *}$ & $0.335^{* * *}$ & $0.311^{* * *}$ & $0.569^{* *}$ & $0.536^{* *}$ & $0.795^{* *}$ & $0.764^{* *}$ \\
\hline & $(0.0536)$ & $(0.0525)$ & $(0.0472)$ & $(0.0456)$ & $(0.203)$ & $(0.197)$ & $(0.270)$ & $(0.254)$ \\
\hline Industry $\mathrm{Fe}$ & Yes & Yes & Yes & Yes & Yes & Yes & Yes & Yes \\
\hline Year Fe & Yes & Yes & Yes & Yes & Yes & Yes & Yes & Yes \\
\hline Targeted X Year & Yes & Yes & No & No & Yes & Yes & No & No \\
\hline Network Controls & No & Yes & No & Yes & No & Yes & No & Yes \\
\hline R-Squared & 0.953 & 0.954 & 0.937 & 0.939 & 0.957 & 0.959 & 0.947 & 0.950 \\
\hline Observations & 4722 & 4722 & 2988 & 2988 & 1751 & 1751 & 1097 & 1097 \\
\hline Clusters & 278 & 278 & 176 & 176 & 88 & 88 & 55 & 55 \\
\hline
\end{tabular}

Note:

Average differences-in-differences estimates, before and after 1973. Regressions interact linkage measure with Post indicator. For these estimates, both linkage interactions are shown (forward and backward); whereas, dynamic estimates presented only linkages for the interaction of interest (forward or backward). Standard errors are clustered at the industry-level and corrected for heteroskedasticity. * Significant at the 10 percent level. ** Significant at the 5 percent level. ${ }^{* * *}$ Significant at the 1 percent level. All specifications are unweighted.

* Source for Panel A - Mining and Manufacturing Survey and Mining and Manufacturing Census: 1970-1986.

${ }^{+}$Source for Panel B - Mining and Manufacturing Survey and Mining and Manufacturing Census: 1967-1986. 


\section{Appendix}

Table A1: Sectoral Acts and HCI Industry

\begin{tabular}{|c|c|c|}
\hline HCI Sector Act & Korean Industry & Translated Industry \\
\hline Steel Industry & 제선 & Iron making \\
\hline Steel Industry & 제강 & Steel making \\
\hline Steel Industry & 압연 & Rolling \\
\hline Steel Industry & 주물용 선철 생산 & Production of pig iron for casting \\
\hline Steel Industry & 합금철 생산 & Ferro alloy production \\
\hline Steel Industry & 강괴 생산 & Steel ingot production \\
\hline Steel Industry & 압연재(제품 포함) 생산 & Production of rolled materials (including products) \\
\hline Steel Industry & 주물 생산 & Casting production \\
\hline Steel Industry & 주단강품 생산 & Casting and forging production \\
\hline Steel Industry & 스텐레스강판 생산 & Production of stainless steel plates \\
\hline Steel Industry & 스텐레스봉강 생산 & Production of stainless steel bars \\
\hline Steel Industry & 고탄소강 생산 & High carbon steel production \\
\hline Steel Industry & 합금강(소재 포함) 생산 & Production of alloy steel (including material) \\
\hline Steel Industry & 전자연철판 생산 & Electronic wrought iron plate production \\
\hline Nonferrous Metal Industry & 동광 & Copper ore \\
\hline Nonferrous Metal Industry & 연광 & Lead ore \\
\hline Nonferrous Metal Industry & 아연광 & Zinc ore \\
\hline Nonferrous Metal Industry & 금광 & Gold ore \\
\hline Nonferrous Metal Industry & 은광 & Silver ore \\
\hline Shipbuilding Industry & 넌박 건조 & Shipbuilding \\
\hline Shipbuilding Industry & 선박 개조 & Ship renovation \\
\hline Shipbuilding Industry & 선박 수리 & Ship repair \\
\hline Shipbuilding Industry & 선박 부분품 제조 & mfg. parts for ships \\
\hline Shipbuilding Industry & 선박 부분품 수리 & Repairing parts of the ship \\
\hline Shipbuilding Industry & 구명기구 & Life equipment \\
\hline Shipbuilding Industry & 항해기구 & Navigation equipment \\
\hline Shipbuilding Industry & 갑판기계 & Deck machinery \\
\hline Chemical Industry & 나프타 분해공업 & Naphtha decomposition industry \\
\hline Chemical Industry & 폴리에틸렌 제조공업 & Polyethylene mfg. industry \\
\hline Chemical Industry & V.C.M. 제조공업 & Vinyl Chloride Monomer mfg. industry \\
\hline Chemical Industry & 스틸렌보노바 제조공업 & Styrenebonova mfg. industry \\
\hline Chemical Industry & 에탄올(합성) 제조공업 & Ethanol (synthetic) mfg. industry \\
\hline Chemical Industry & 아세트 알데히트 제조공업 & Acetaldehyde mfg. industry \\
\hline Chemical Industry & 부탄올 제조공업 & Butanol mfg. industry \\
\hline Chemical Industry & 옥탄올 제조공업 & Octanol mfg. industry \\
\hline Chemical Industry & 빙초산 제조공업 & Glacial acetic acid mfg. industry \\
\hline Chemical Industry & 아크릴로니트릴 제조공업 & Acrylonitrile mfg. industry \\
\hline Chemical Industry & 알킬벤젠 제조공업 & Alkylbenzene mfg. industry \\
\hline Chemical Industry & 폴리푸로필렌 제조공업 & Polypropylene mfg. industry \\
\hline Chemical Industry & 합성고무(S.B.R.) 제조공업 & Styrene Butadiene Rubber mfg. industry \\
\hline Chemical Industry & 씨크로헥산 제조공업 & Cyclohexane mfg. industry \\
\hline Chemical Industry & 훼놀 제조공업 & Phenol mfg. industry \\
\hline Chemical Industry & 아니린 제조공업 & Aniline mfg. industry \\
\hline Chemical Industry & 무수푸탈산 제조공업 & Phthalic anhydride mfg. industry \\
\hline Chemical Industry & 메탄올 제조공업 & Methanol mfg. industry \\
\hline Chemical Industry & 카본불랙 제조공업 & Carbon black mfg. Industry \\
\hline Chemical Industry & 포리스틸랜 제조공업 & Polystyrene mfg. industry \\
\hline Chemical Industry & 카프로락탐 제조공업 & Caprolactam mfg. industry \\
\hline Chemical Industry & 암모니아 제조공업(석유화학공업연료로 공급하는 것에 한함) & Ammonia mfg. industry (limited to supply as petrochemical fuel) \\
\hline Chemical Industry & D.M.T. 제조공업 & Dimethyl Terephthalate mfg. industry \\
\hline Chemical Industry & 에틸렌그리클 제조공업 & Ethylene glycol mfg. industry \\
\hline Chemical Industry & 폴리푸로필렌그리콜 제조공업 & Polypropylene glycol mfg. industry \\
\hline Chemical Industry & 테레프탈산(T.P.A.) 제조공업 & Terephthalic Acid mfg. industry \\
\hline Chemical Industry & 무수마레인산 제조공업 & Maleic anhydride mfg. industry \\
\hline Chemical Industry & 큐멘 제조공업 & Cumene mfg. industry \\
\hline Chemical Industry & 아세톤 제조공업 & Acetone mfg. industry \\
\hline Chemical Industry & 2염화 에틸렌(E.D.C.) 제조공업 & Ethylene Dichloride mfg. industry \\
\hline Chemical Industry & 펜타에리스리틀 제조공업 & Pentaerythrityl mfg. industry \\
\hline Chemical Industry & 키시렌분유공업 & Xylene milk powder industry \\
\hline Chemical Industry & 산화푸로필렌제조공업 & Propylene oxide mfg. industry \\
\hline Chemical Industry & 산화에틸렌제조공업 & Ethylene oxide mfg. industry \\
\hline Chemical Industry & 염소제조공업(석유화학 원료로 공급하는 것에 한한다) & Chlorine mfg. industry (limited to supply as petrochemical fuel) \\
\hline Chemical Industry & 톨루엔 디 이소시아네이트제조공업 & Toluene diisocyanate mfg. industry \\
\hline Chemical Industry & 메틸메타 아그레이트모노 마제조공업(중간체인 시안화합물을 포함한다) & Methyl methacrylate monomer mfg. industry (including intermediate cyanide compound) \\
\hline Chemical Industry & 합성고무(폴리부타디엔 고무에 한한다) 제조공업 & Synthetic rubber (limited to polybutadiene rubber) mfg. industry \\
\hline Chemical Industry & 초산비닐모노마제조공업 & Vinyl acetate monomer mfg. industry \\
\hline Chemical Industry & 염화비니리딘수지제조공업 & Viniridine chloride resin mfg. industry \\
\hline Chemical Industry & 석유수지제조공업 & Petroleum resin mfg. industry \\
\hline Chemical Industry & 정파라핀(노루말 파라핀에 한한다)제조공업 & Regular paraffin (limited to normal paraffin) $\mathrm{mfg}$. industry \\
\hline Chemical Industry & 폴리비닐 알콜제조공업 & Polyvinyl alcohol mfg. industry \\
\hline Chemical Industry & 초산에틸제조공업 & Ethyl acetate mfg. industry \\
\hline Machine Industry & 보일러 및 원자로 & Boiler and reactor \\
\hline Machine Industry & 내연기관 및터빈 & Internal combustion engine and turbine \\
\hline Machine Industry & 축수 & Bearing \\
\hline Machine Industry & 동력전달장치 & Power transmission device \\
\hline Machine Industry & 볼트 및 너트 & Bolt and nut \\
\hline Machine Industry & 금속공작기계 & Metal machine tools \\
\hline Machine Industry & 금속1차제품제조기 & Metal primary product mfg. machine \\
\hline Machine Industry & 제 2 차금속가공기계 & Secondary metal processing machine \\
\hline Machine Industry & 용접기계 & Welding machine \\
\hline Machine Industry & 금형 & Mold \\
\hline Machine Industry & 공구 & Tool \\
\hline Machine Industry & 전구 & Electric bulb \\
\hline Machine Industry & 펌프, 송풍기, 압축기 & Pump, blower, compressor \\
\hline Machine Industry & 유압기계 & Hydraulic machine \\
\hline Machine Industry & 냉동기 및 공기조절장치 & Refrigerator and air conditioner \\
\hline Machine Industry & 화학기계 & Chemical instruments \\
\hline Machine Industry & 하역운반기계 & Unloading machine \\
\hline Machine Industry & 광산기계 & Mining machine \\
\hline Machine Industry & 토목건설기계 & Civil construction machine \\
\hline
\end{tabular}


Table A1: Sectoral Acts and HCI Industry (continued)

\begin{tabular}{|c|c|c|}
\hline HCI Sector Act & Korean Industry & Translated Industry \\
\hline Machine Industry & 플라스틱 성형가공기계 & Plastic molding machine \\
\hline Machine Industry & 섬유기계 & Textile machine \\
\hline Machine Industry & 팔프 제지 지공기계 & Pulp paper making machine \\
\hline Machine Industry & 포장 하조기계 & Packaging machine \\
\hline Machine Industry & 인쇄제본기계 & Machine for printing and binding \\
\hline Machine Industry & 목공기계 & Woodworking machine \\
\hline Machine Industry & 식료 및 음료가공기계 & Food and beverage processing machine \\
\hline Machine Industry & 농업용기계 & Agricultural machine \\
\hline Machine Industry & 공업용 로 및 발열기기 & Industrial furnaces and heating device \\
\hline Machine Industry & 주조장치 & Casting machine \\
\hline Machine Industry & 밸브 및 관이음쇠 & Valve and pipe joints \\
\hline Machine Industry & 계측기계 & Measuring machine \\
\hline Machine Industry & 시계 & Clock \\
\hline Machine Industry & 광학기계 & Optical machine \\
\hline Machine Industry & 사무용기계 & Office machine \\
\hline Machine Industry & 재봉기 & Sewing machine \\
\hline Machine Industry & 제약 및 의료용기기 & Pharmaceutical and medical device \\
\hline Machine Industry & 중전기 장치 & Heavy electric device \\
\hline Machine Industry & 가정용 전기기기 & Home appliance \\
\hline Machine Industry & 조명기기 & Lighting equipment \\
\hline Machine Industry & 전지 및 축전기 & Battery and capacitor \\
\hline Machine Industry & 유무선 통신장치 & Wired and wireless communication device \\
\hline Machine Industry & 방송 및 수신장치 & Broadcasting and receiving device \\
\hline Machine Industry & 전자응용장치 & Electronic application device \\
\hline Machine Industry & 전선 및 케이블 & Wires and cables \\
\hline Machine Industry & 자동차 & Car \\
\hline Machine Industry & 자전차 & Bicycle \\
\hline Machine Industry & 산업차량 & Industrial vehicle \\
\hline Machine Industry & 철도차량 & Railway vehicle \\
\hline Machine Industry & 선박 & Vessel \\
\hline Machine Industry & 항공기 & Aircraft \\
\hline Machine Industry & 교통 신호보안 관제장치 & Traffic signal security control system \\
\hline Machine Industry & 민수용 총기 & Civil gun \\
\hline Machine Industry & 주물 & Casting \\
\hline Machine Industry & 기계기구용 비철금속 단조품과 프레스제품 & Nonferrous metal forging and press products for machinery \\
\hline Machine Industry & 방위산업용기기 및 장비 & Equipment for the defense industry \\
\hline Machine Industry & 특수강제품 & Special steel product \\
\hline Electronics Industry & 라듸오수신기 & Radio receiver \\
\hline Electronics Industry & 텔레비존수상기 & Television \\
\hline Electronics Industry & 음성주파장치 & Voice frequency device \\
\hline Electronics Industry & 통신기계기구 & Communication equipment \\
\hline Electronics Industry & 무선응용장치 & Wireless application device \\
\hline Electronics Industry & 전자응용장치 & Electronic application device \\
\hline Electronics Industry & 전기계측기 & Electrical measuring instrument \\
\hline Electronics Industry & 전자관 & Electronic tube \\
\hline Electronics Industry & 반도체소자 & Semiconductor device \\
\hline Electronics Industry & 직접회로 & Integrated crcuit \\
\hline Electronics Industry & 회로부품 & Circuit parts \\
\hline Electronics Industry & 음향부품 & Sound components \\
\hline Electronics Industry & 기구부품 & Equipment parts \\
\hline Electronics Industry & 집합부품 & Assembly parts \\
\hline Electronics Industry & 기타 기계·금속·화공계열부품 & Other mechanical, metal, and chemical parts \\
\hline Electronics Industry & 자기재료 & Magnetic material \\
\hline Electronics Industry & 절연재료 & Insulating material \\
\hline Electronics Industry & 도전재료 & Conductive material \\
\hline Electronics Industry & 반도체재료 & Semiconductor material \\
\hline Electronics Industry & 특수재료 & Special material \\
\hline
\end{tabular}

Source notes:

List of sectoral acts and industries falling under $\mathrm{HCI}$ incentive programs. Large cells are the original six sector acts that underpinned the HCI plan. Industries are those markets falling under the acts. Sectoral acts were defined before the HCI drive announcement (see text), and minor additions were made to subsequent enforcement decrees defined after the original acts. I cite, for completeness, the more final enforcement decrees from these acts. In a small number of cases, some products were added to the lists.

* GigyegongEnforcement Decree of the Machinery Industry Promotion Act], amended by Presidential Decree No. 7850, Oct. 27, 1975 (S. Kor.). Cheolganggong-eopyukseongbeop [Steel Industry Promotion Act], amended by Act. No. 3011, Dec. 16, 1977 (S. Kor.). Cheolganggong-eopyukseongbeopsihaengryung [Enforcement Decree of the Steel Industry Promotion Act], amended by Presidential Decree No. 8885, Mar. 9, 1978 (S. Kor.). Bicheolgeumsokjeryeonsa-eopbeop [Nonferrous Metal Industry Promotion Act], amended by Act. No. 3011, Dec. 16, 1977 (S. Kor.). Bicheolgeumsokjeryeonsa-eopbeopsihaengryung [Enforcement Decree of the Nonferrous Metal Industry Promotion Act], amended by Presidential Decree No. 7743 , Aug. 20, 1975 (S. Kor.). Jeonjagong-eopjinheungbeopsihaengryung [Enforcement Decree of the Electronics Industry Promotion Act], amended by Presidential Decree No. 8272, Nov. 5, 1976 (S. Kor.). Joseon-gongeopjinheungbeop [Shipbuilding Industry Promotion Act], amended by Act. No. 3339, Dec. 31, 1980 (S. Kor.). Joseon-gong-eopjinheungbeopsihaenggyuchik, amended by Decree by the Ministry of Commerce No. 411, Dec. 8, 1975 (S. Kor.).Seokyuhwahakgong-eopyukseongbeopsihaengryung [Enforcement Decree of the Petrochemical Industry Promotion Act], amended by Presidential Decree No. 10331, June 5, 1981 (S. Kor.) 
Figure A1: New Loans Issued By Traditional Commercial Deposit Money Banks, 1966-1983

Panel A - New Total Lending by Deposit Money Banks

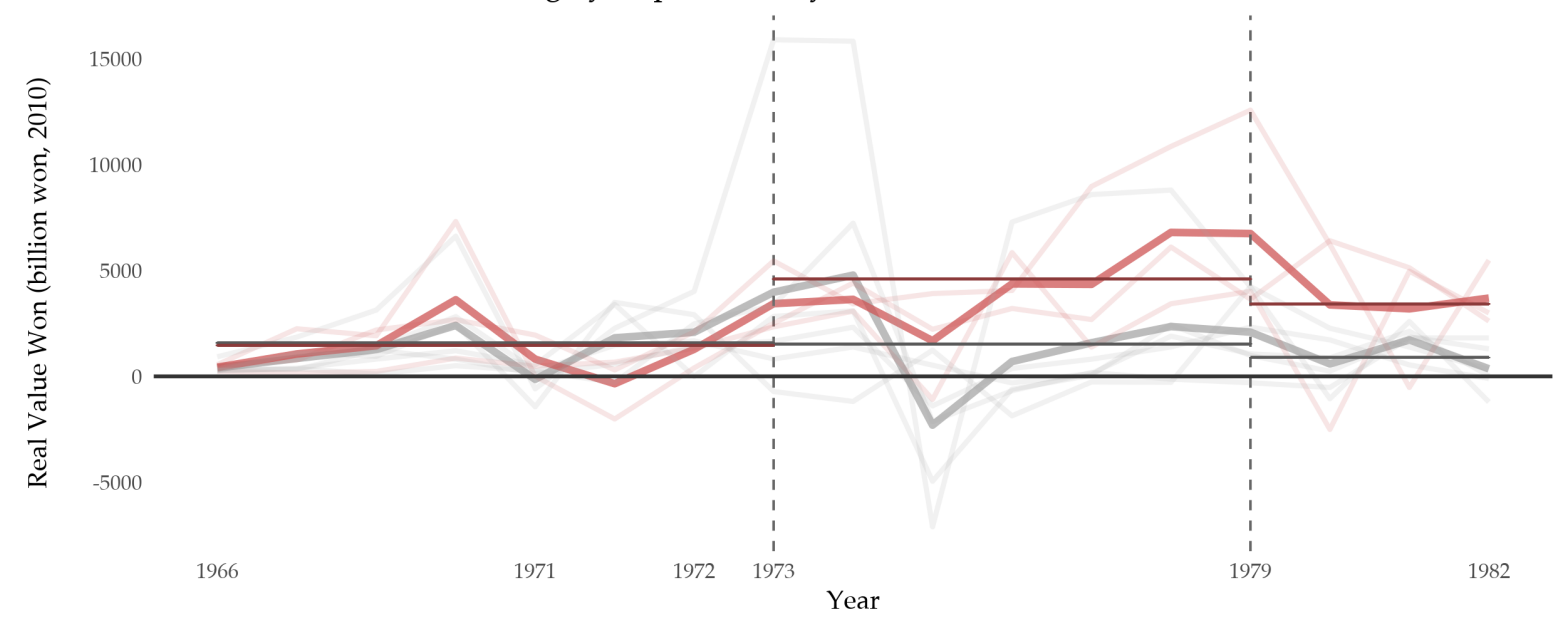

Panel B - New Machinery Lending by Deposit Money Banks

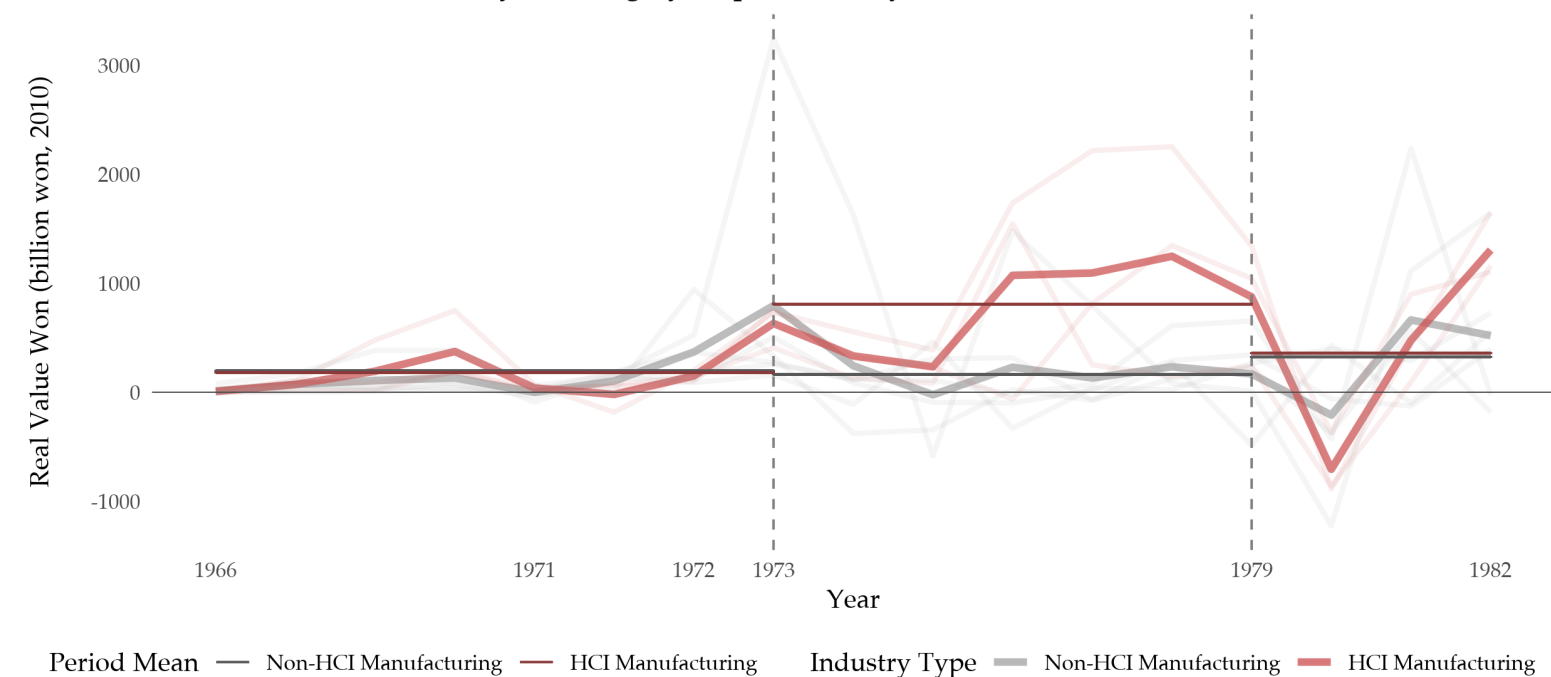

Notes: Plots show the change in the real value of loans issued by the South Korean commercial banks (traditional deposit money banks). The top panel
plots changes in total new lending. Bottom panel plots new lending for machinery loans only. Units are real value in 2010 won (billions). Gray lines

correspond to non-targeted sectors. Red lines correspond to targeted sectors. Thick lines show averages by treated and non-treated sectors. Subsidized

'policy loans' were lent through the commercial banking sector. See Section 2 for details. After 1979, the banking sector was liberalized, and the

differences in policy interest rates were eliminated. The cost of borrowing converged between HCI and non-HCI converged. Source: Korean Yearbooks. 
Table A2: Differences in Trade Policy, HCI v. Non-HCI Industry, 1968 Only

\begin{tabular}{|c|c|c|c|c|}
\hline & \multicolumn{2}{|c|}{ Tariff Rate } & \multicolumn{2}{|c|}{ QRs Coverage } \\
\hline & 1 & 2 & 3 & 4 \\
\hline \multicolumn{5}{|c|}{ Outcomes: Levels of Output Protection } \\
\hline Targeted & $\begin{array}{l}-0.504^{* * *} \\
(0.135)\end{array}$ & $\begin{array}{l}-0.434^{* * *} \\
(0.121)\end{array}$ & $\begin{array}{l}-0.315^{* *} \\
(0.097)\end{array}$ & $\begin{array}{l}-0.246^{* *} \\
(0.076)\end{array}$ \\
\hline Year Effect & Yes & Yes & Yes & Yes \\
\hline Sample & 1968 Only & 1968 Only & 1968 Only & 1968 Only \\
\hline Weighted & None & Weighted & None & Weighted \\
\hline R-Squared & 0.139 & 0.129 & 0.109 & 0.107 \\
\hline Observations & 88 & 88 & 88 & 88 \\
\hline N Cluster & . & . & . & . \\
\hline \multicolumn{5}{|l|}{ Note: } \\
\hline \multicolumn{5}{|c|}{$\begin{array}{l}\text { Table shows the cross-sectional relationship between trade policy and } \\
\text { HCI (Targeted industries), using nominal trade policy data for the year } \\
\text { 1968, the year of trade policy data before HCI. All regressions are at the } \\
\text { 4-digit industry level. The first set of columns report results for regres- } \\
\text { sions in levels. The second set of columns reports differences outcomes. } \\
\text { Columns (1-2) report estimates for tariffs. Columns } 3-4 \text { reports estimates } \\
\text { for quantitative restriction coverage (QR). }{ }^{*} \text { Significant at the } 10 \text { percent } \\
\text { level. ** Significant at the } 5 \text { percent level. ** Significant at the } 1 \text { percent } \\
\text { level. } \\
\text { Source - Tariffs rates and QR coverage, Luedde-Neurath (1986). }\end{array}$} \\
\hline
\end{tabular}


Table A3: Pre-HCI Drive Statistics Across Manufacturing Industry - By Panel and Treatment

\begin{tabular}{|c|c|c|c|c|c|c|c|}
\hline \multirow[b]{2}{*}{$\mathrm{HCI}$} & \multirow[b]{2}{*}{ Variable } & \multicolumn{3}{|c|}{ A) 4-Digit Panel 1967-1972 } & \multicolumn{3}{|c|}{ B) 5-Digit Panel 1970-1972 } \\
\hline & & Mean & Stdev. & Obs. & Mean & Stdev. & Obs. \\
\hline \multicolumn{8}{|c|}{ i. Industrial Statistics } \\
\hline Non-HCI & Average Size & 3.70 & 3.07 & 330 & 3.26 & 3.53 & 528 \\
\hline $\mathrm{HCI}$ & Average Size & 2.88 & 2.47 & 198 & 2.78 & 3.01 & 306 \\
\hline Non-HCI & Establishments & 404.94 & 573.99 & 330 & 106.35 & 239.13 & 528 \\
\hline $\mathrm{HCI}$ & Establishments & 162.23 & 207.08 & 198 & 50.22 & 78.49 & 306 \\
\hline Non-HCI & Gross Output & 182283.73 & 268697.65 & 330 & 75534.11 & 171985.04 & 528 \\
\hline $\mathrm{HCI}$ & Gross Output & 149872.90 & 316962.55 & 198 & 61968.10 & 197701.15 & 306 \\
\hline Non-HCI & Investment & 6624.47 & 13217.23 & 330 & 2261.10 & 5220.20 & 528 \\
\hline $\mathrm{HCI}$ & Investment & 8123.71 & 23626.80 & 198 & 3351.19 & 15308.23 & 306 \\
\hline Non-HCI & Labor Productivity & 740.74 & 915.77 & 330 & 708.96 & 1034.00 & 528 \\
\hline $\mathrm{HCI}$ & Labor Productivity & 867.80 & 2370.54 & 198 & 744.37 & 1689.35 & 306 \\
\hline Non-HCI & Labor Share (X 100) & 1.38 & 1.77 & 330 & 0.42 & 0.77 & 528 \\
\hline $\mathrm{HCI}$ & Labor Share (X 100) & 0.72 & 0.77 & 198 & 0.24 & 0.33 & 306 \\
\hline Non-HCI & Prices & 9.70 & 4.97 & 330 & 10.97 & 5.08 & 528 \\
\hline $\mathrm{HCI}$ & Prices & 29.20 & 41.45 & 198 & 29.14 & 36.67 & 306 \\
\hline Non-HCI & Value Added & 85336.99 & 154925.03 & 330 & 31335.02 & 68599.31 & 528 \\
\hline $\mathrm{HCI}$ & Value Added & 51414.51 & 103408.20 & 198 & 22038.69 & 67048.19 & 306 \\
\hline Non-HCI & Value Added Share (X 100) & 1.33 & 2.44 & 330 & 0.37 & 0.81 & 528 \\
\hline $\mathrm{HCI}$ & Value Added Share (X 100) & 0.78 & 1.47 & 198 & 0.26 & 0.80 & 306 \\
\hline Non-HCI & Workers & 12979.95 & 16910.92 & 330 & 4117.89 & 7565.39 & 528 \\
\hline $\mathrm{HCI}$ & Workers & 6775.03 & 7475.16 & 198 & 2351.84 & 3264.28 & 306 \\
\hline \multicolumn{8}{|c|}{ ii. Linkage Measures } \\
\hline Non-HCI & Backward, Upstream From Hci & 0.09 & 0.15 & 330 & 0.13 & 0.24 & 528 \\
\hline $\mathrm{HCI}$ & Backward, Upstream From Hci & 0.13 & 0.20 & 198 & 0.16 & 0.20 & 306 \\
\hline Non-HCI & Forward, Downstream From Hci & 0.20 & 0.18 & 330 & 0.19 & 0.16 & 528 \\
\hline $\mathrm{HCI}$ & Forward, Downstream From Hci & 0.45 & 0.20 & 198 & 0.50 & 0.19 & 306 \\
\hline \multicolumn{8}{|c|}{ iii. Trade Statistics } \\
\hline Non-HCI & Rca (Belassa) & 1.42 & 5.76 & 3464 & & & \\
\hline $\mathrm{HCI}$ & Rca (Belassa) & 0.43 & 1.93 & 1448 & & & \\
\hline Non-HCI & Export Share (X 100) & 0.17 & 0.81 & 3464 & & & \\
\hline $\mathrm{HCI}$ & Export Share (X 100) & 0.09 & 0.41 & 1448 & & & \\
\hline Non-HCI & Import Share (X 100) & 0.12 & 0.52 & 3464 & & & \\
\hline $\mathrm{HCI}$ & Import Share (X 100) & 0.24 & 0.49 & 1448 & & & \\
\hline Non-HCI & Real Value Imports & 8581.49 & 38564.63 & 3464 & & & \\
\hline $\mathrm{HCI}$ & Real Value Imports & 17679.37 & 39295.52 & 1448 & & & \\
\hline Non-HCI & Real Value Exports & 5048.82 & 26924.41 & 3464 & & & \\
\hline $\mathrm{HCI}$ & Real Value Exports & 2822.49 & 14837.09 & 1448 & & & \\
\hline
\end{tabular}

Note:

Table reports pre-1973 statistics for a selection of core industrial variables. Panel A shows statistics for aggregated ('long') 4-digit industrial panel, 1967 to 1972. Panel B shows statistics for disaggregated ('short') 5-digit industrial panel, 1970 to 1972. Raw (non-normalized) values are shown. Part i) of table reports Mining and Manufacturing Survey/Census outcomes. With the exception of prices, which come from the Bank of Korea publications. Part ii) shows data from the 1970 input-output tables published by the Bank of Korea (1970), harmonized and matched to industry-level data. Part iii) shows trade (UN-COMTRADE) variables, harmonized and matched to 4-digit industry-level data. Trade policy variables are also shown: tariffs and quantitative restrictions (QRs). Tariffs are reported as ad velorum rates. QRs, are coverage scores of industry restrictions: lowest (0) to highest (3) (Luedde-Neurath 1986). All values, including trade values, have been converted to real Won (base year, 2010). 
Figure B1: Differences in Value Added Per Worker and Output Prices, Relative to 1972

A) Labor Productivity

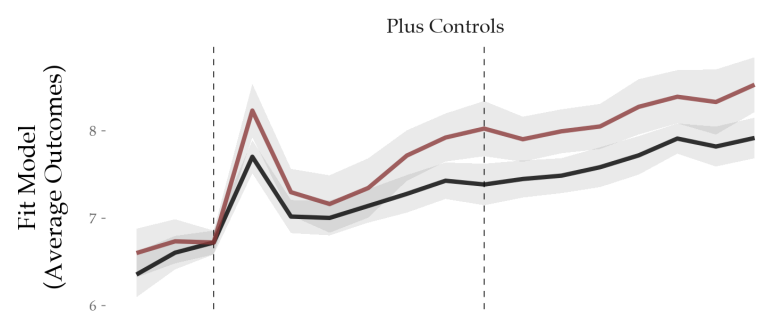

B) Output Prices
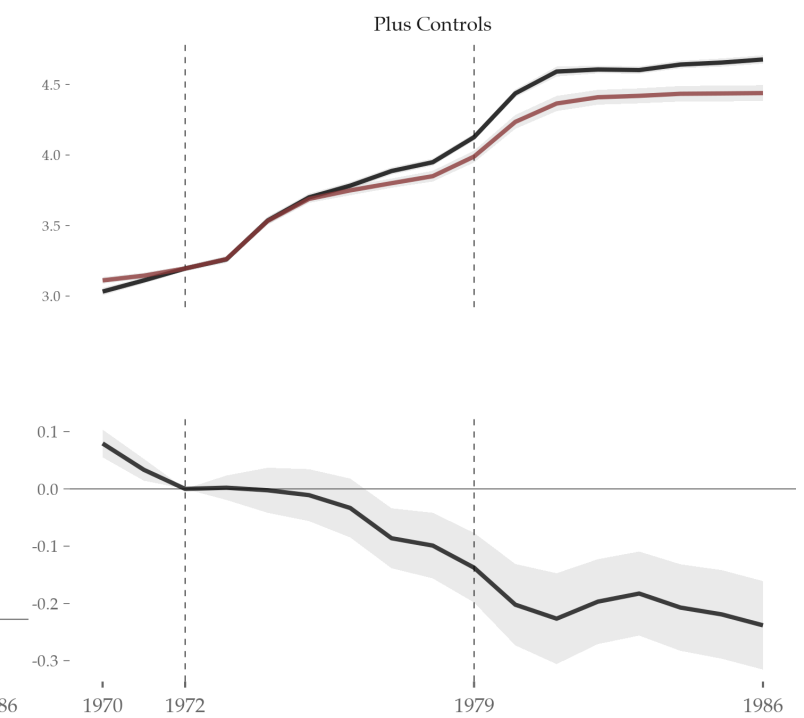

- Non-HCI

$$
\text { - HCI }
$$

Note: Figure shows dynamic differences-in-differences estimates for the relationship between HCI and labor productivity (value added per worker) in Panel A and output prices in Panel B. Top row shows the averages for HCI (red) and non-HCI industry (black). Bottom row plots dynamic differences-in-differences estimates from the regression. Estimates are relative to 1972, the year before the HCI policy. 1973 is the start of HCI. The line at 1979 demarcates the fall of the

Park regime. Standard errors are clustered at the industry-level and corrected for heteroskedasticity. Confidence bands are in light grey and are 95 percent confidence intervals. 
Figure B2: Relationship Between HCI and TFP, Industry-Level Estimates, 1970-1986

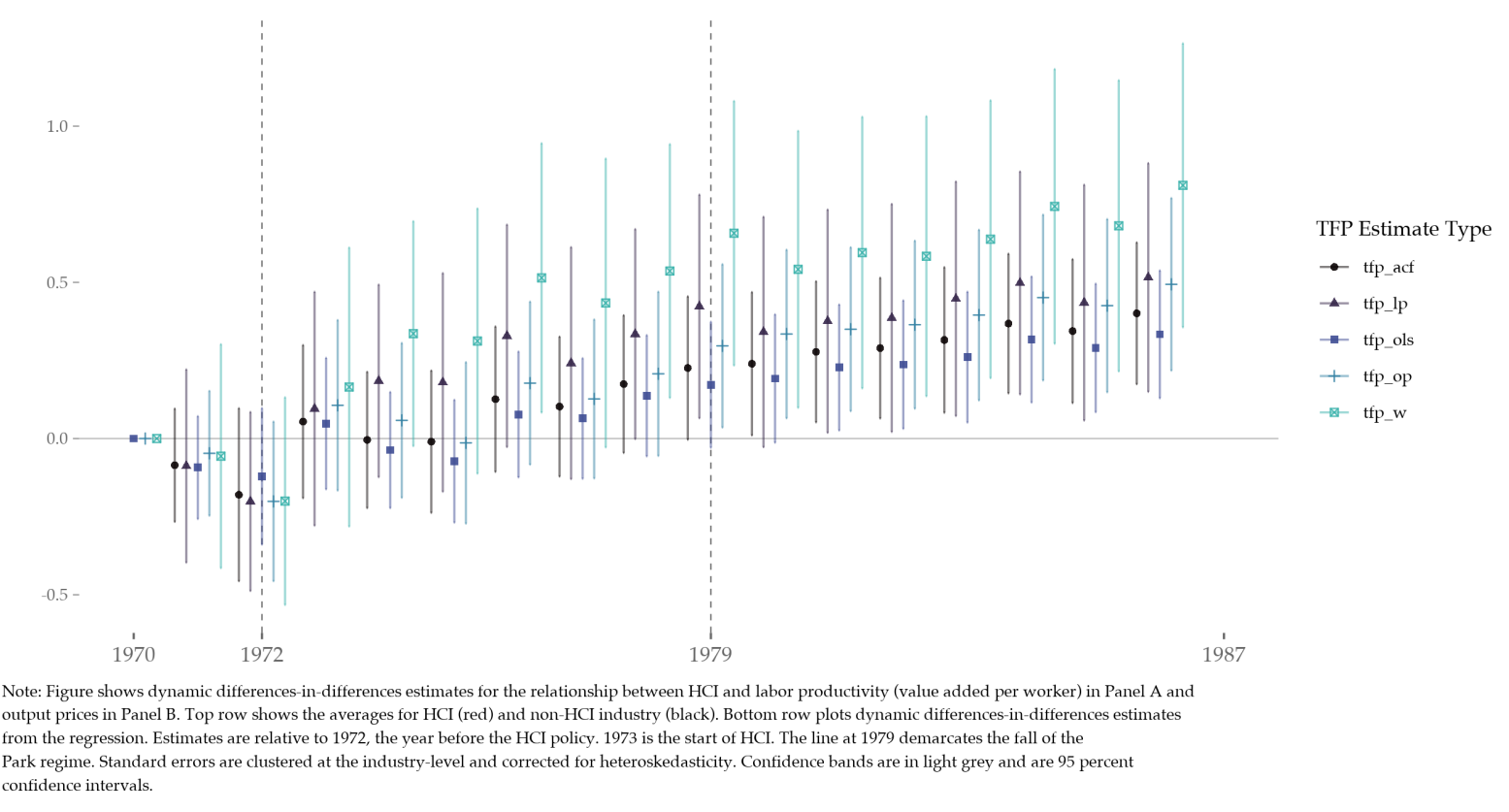

Figure B3: Relative Growth in TFP Post 1979, Micro-Estimates

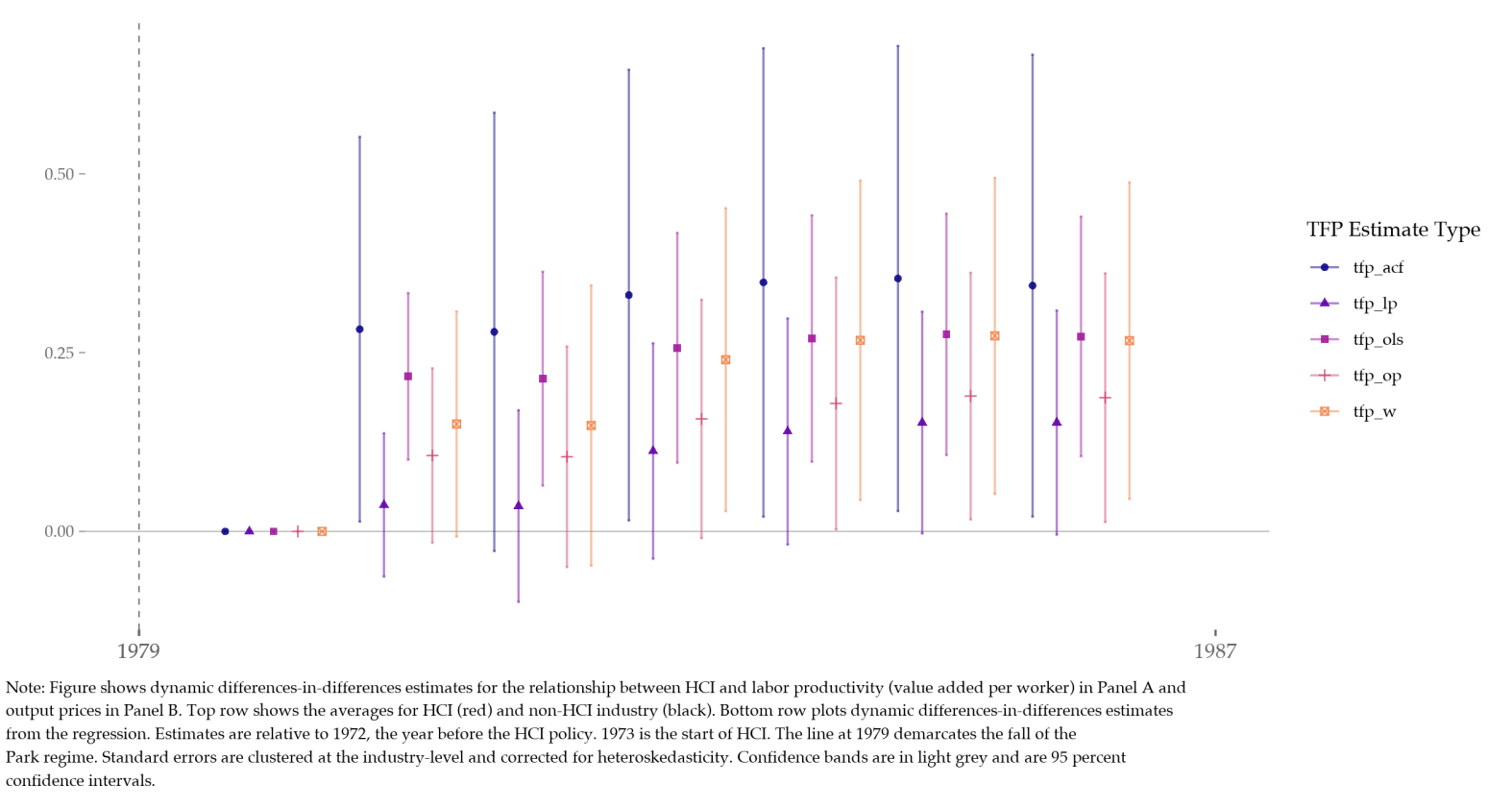


Figure B4: Impact of HCI (Continuous Measure) on Industrial Development

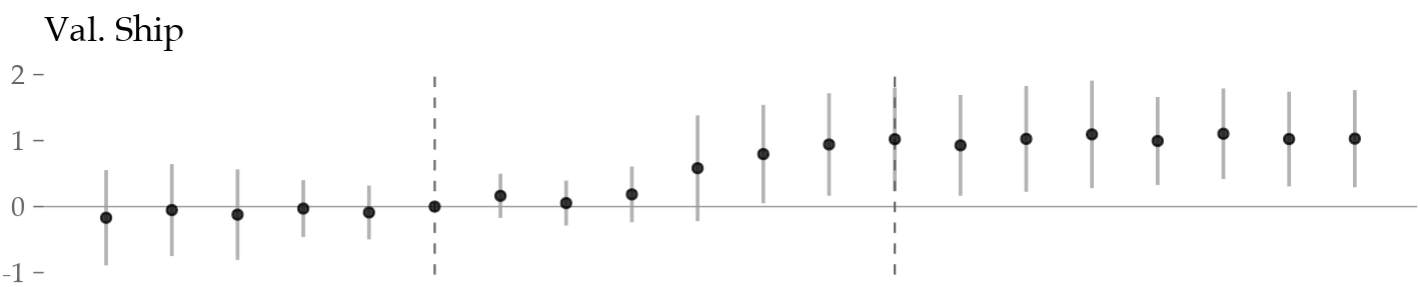

Labor Prod.

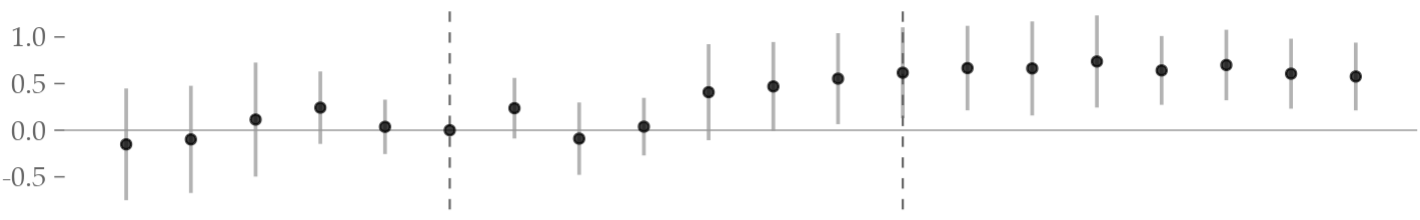

Prices

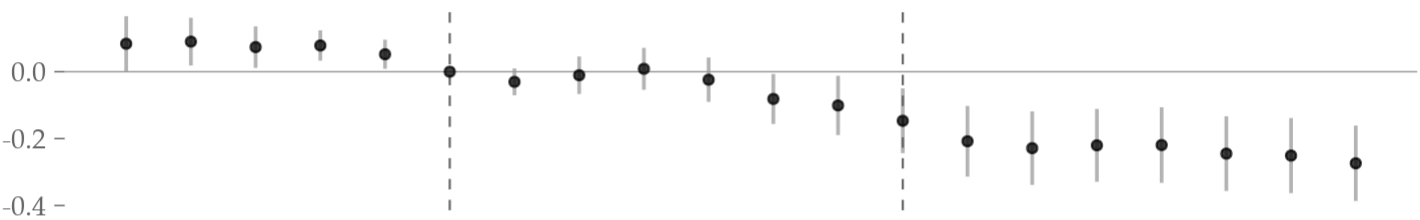

Employment

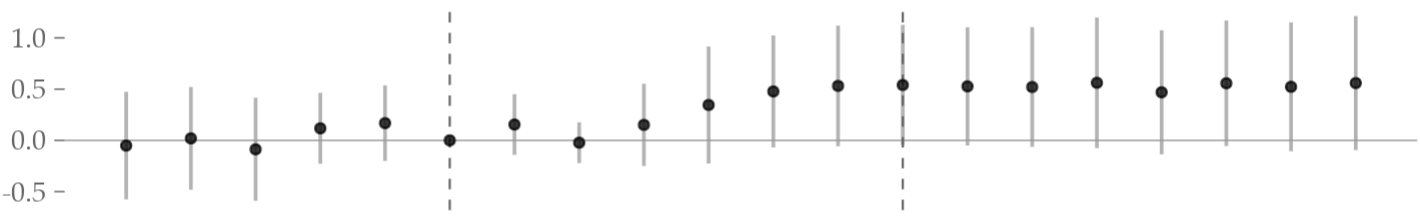

Num. Plants

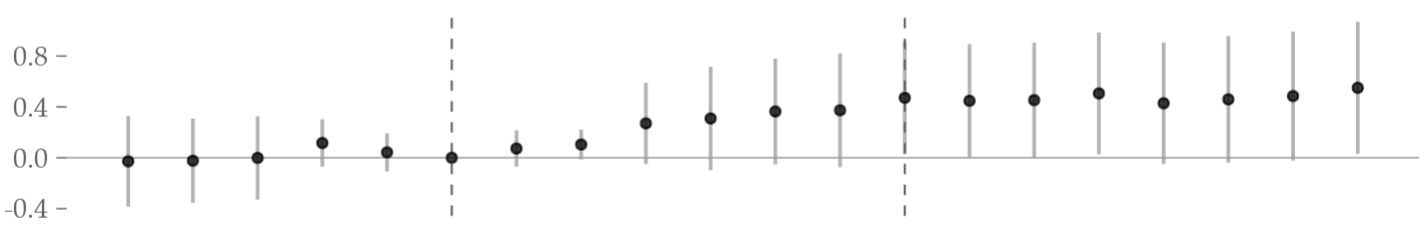

Output Share

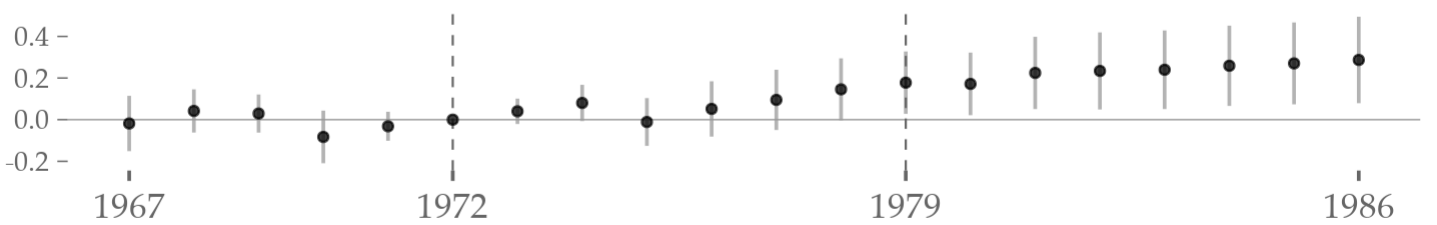

Note: Figure shows dynamic differences-in-differences estimates for the relationship between HCI and industrial development outcomes. HCI here is a continuous measure: the share of an industry's product-level output from in 8-digit

HCI products (see text for details). Shipments are the real value shipped. Labor productivity is real value added over number of workers. Employment is the number of workers. Output share is the manufacturing share of industry output. Prices are industry-level output prices. Num. Plants are the number of establishments operating in a given industry. All outcomes are ihs normalized to deal with 0 s and (where possible) negative values. All regressions are estimated using a two-way fixed effect specification, and include baseline controls (pre-1973 wages, plant size, and labour productivity and costs) interacted with time effects. Figure plots coefficients of interest from intereaction of interest: HCI x Year. Estimates are relative to 1972, the year before the HCI policy intervention. The line at 1972 is the start of the policy. The line at 1979 demarcates the fall of the Park regime. Standard errors are clustered at the industry-level and corrected for heteroskedasticity. Confidence bands are in light grey and correspond to 95 percent confidence intervals. 
Figure B5: Doubly-Robust Estimates Across Industrial Development Outcomes, 4 Digit Industry Panel

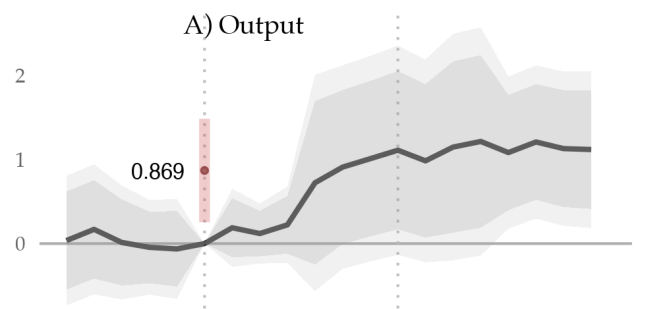

D) Labor Prod.
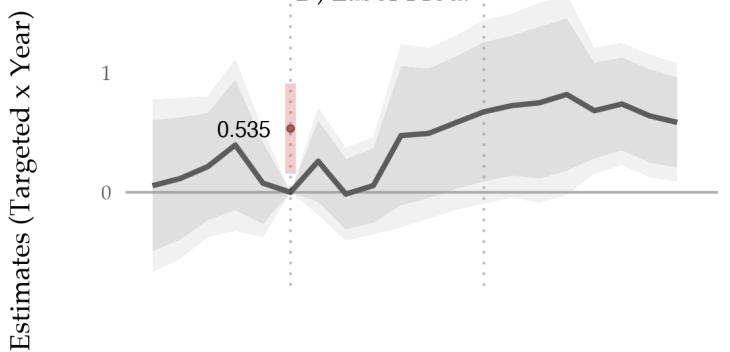

G) Num. Plants

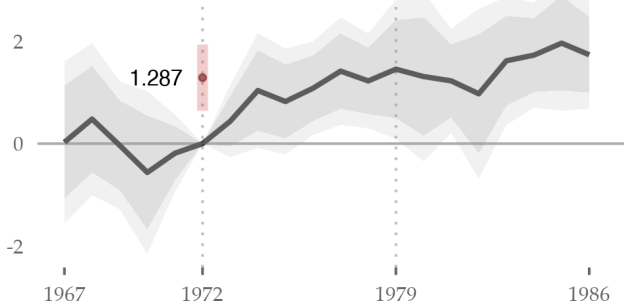

1.5

1.0

0.5

0.0

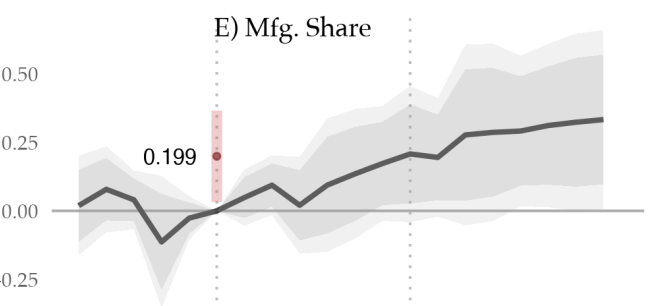

B) Workers

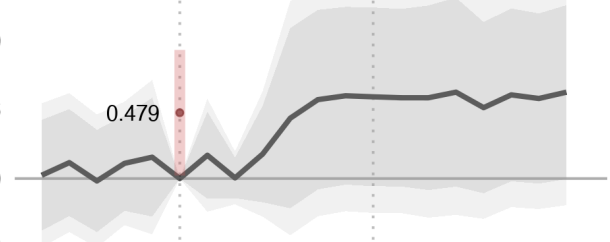

0.2

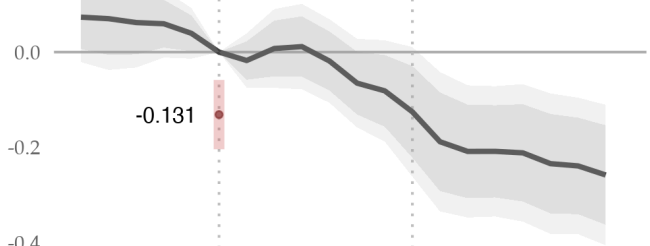

F) Lab. Share

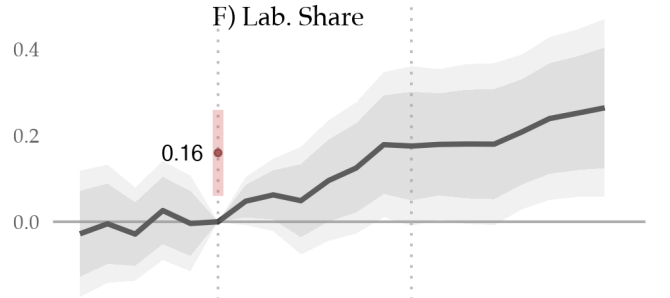

$-0.2$

H) Export Share

0.4

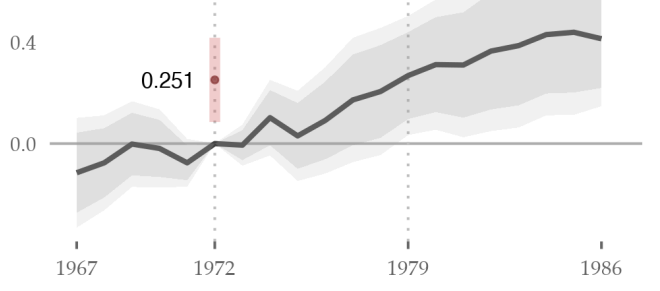

Year

Notes: This figure plots semiparametric (doubly-robust) differences-in-differences estimates for the impact of HCI on core industrial development outcomes. They include (ihs) value of shipments; employment; output prices; labor productivity (value added per worker); mfg. share (manufacturing share of output shipped); lab. share (manufacturing share of employment); number of plants; and import and export share (manufacturing share of trade values).. All values are real (2010). This figure reports estimates for longer 4-digit industrial series (1967-1986). Average treatment effect on treated (ATT) shown by the bold red dot. The light red error bar is the 95 percent confidence interval. Semiparametric estimates for each year are plotted by the dark lines. All point estimates are relative to the 1972 baseline level (coefficients normalized to 0 ). The 95 confidence bands are in light gray; 90 percent, are in dark gray. Standard errors are from a bootstrap procedure (10,000 iterations) and allow for within industry correlation. Specifications are made to be as close as possible to two-way fixed effects estimates. Controls are the same baseline covaraiates used across in linear specifications: (pre-1973) average wagebill, average plant size, total costs, and labor productivity. 
Figure B6: Doubly-Robust Estimates Across Industrial Development Outcomes, 5 Digit Industry Panel
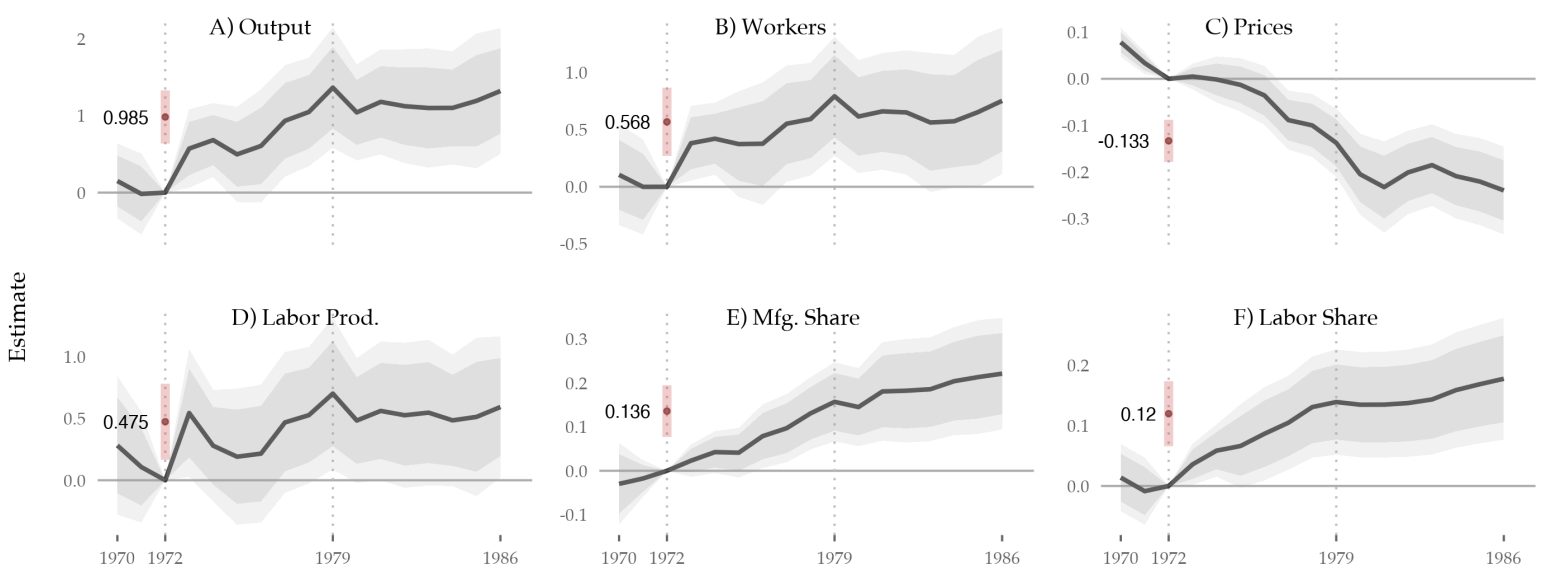

Year

Notes: This figure plots semiparametric (doubly-robust) differences-in-differences estimates for the impact of HCI on core industrial development outcomes. They include (ihs) value of shipments; employment; output prices; labor productivity (value added per worker); mfg. share (manufacturing share of output shipped); lab. share (manufacturing share of employment). All values are real (2010). This figure reports estimates for detailed 5-digit industrial series (1970-1986). Average treatment effect on treated (ATT) shown by the bold red dot. The light red error bar is the 95 percent confidence interval. Semiparametric estimates for each year are plotted by the dark lines. All point estimates are relative to the 1972 baseline level (coefficients normalized to 0). The 95 confidence bands are in light gray; 90 percent, are in dark gray. Standard errors are from a bootstrap procedure (10,000 iterations) and allow for within industry correlation. Specifications are made to be as close as possible to two-way fixed effects estimates. Controls are the same baseline covaraiates used across in linear specifications: (pre-1973) average wagebill, average plant size, total costs, and labor productivity.

Figure B7: Doubly-Robust Estimates Across Industrial Development Outcomes, Trade Data Panel

$2 \quad$ A) RCA
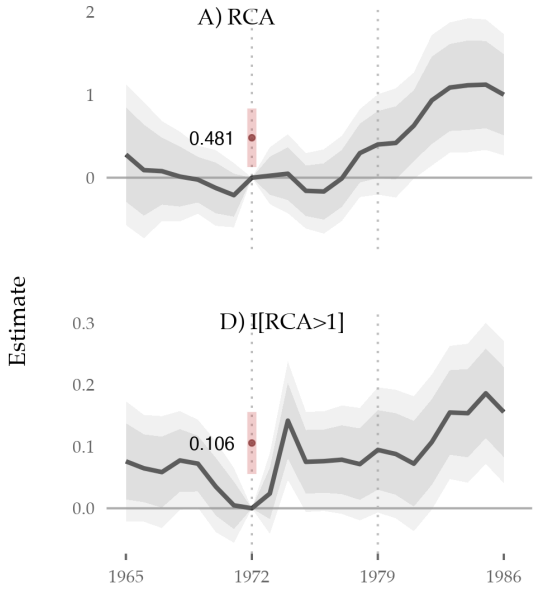
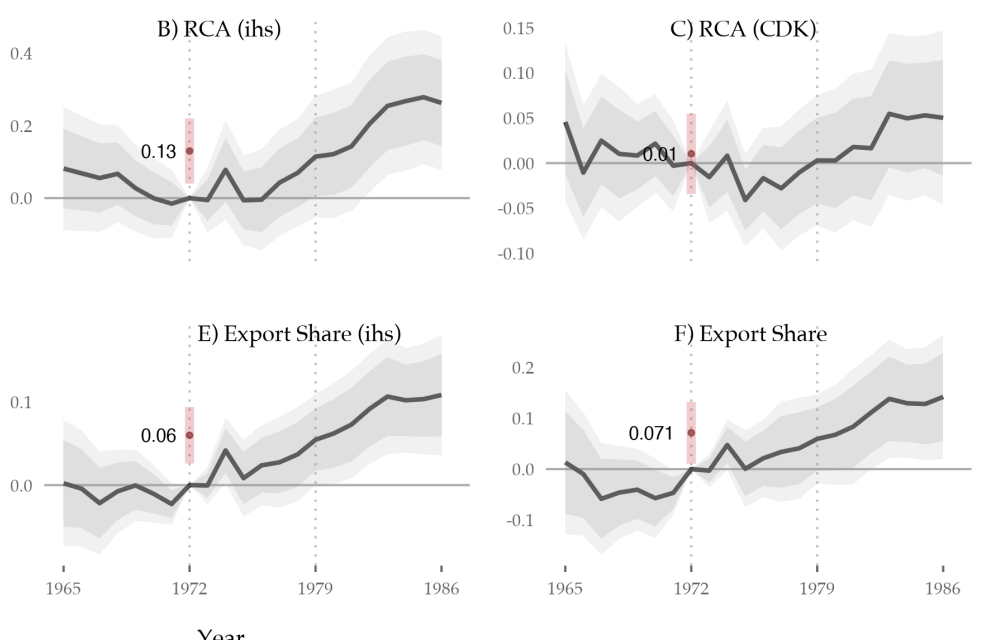

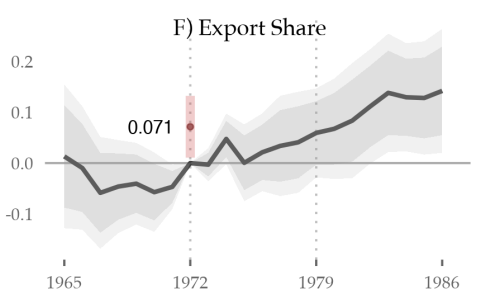

Notes: This figure plots semiparametric (doubly-robust) differences-in-differences estimates for the impact of HCI on trade development and comparative advantage outcomes. All values are real (2010). This figure reports estimates for longer 4-digit SITC series (1965-1986). Average treatment effect on treated (ATT) shown by the bold red dot. The light red error bar is the 95 percent confidence interval. Semiparametric estimates for each year are plotted by the dark lines. All point estimates are relative to the 1972 baseline level (coefficients normalized to 0). The 95 confidence bands are in light gray; 90 percent, are in dark gray. Standard errors are from a bootstrap procedure (10,000 iterations) and allow for within industry correlation. Specifications are made to be as close as possible to two-way fixed effects estimates. Controls are the same baseline covaraiates used across in linear specifications: (pre-1973) average wagebill, average plant size, total costs, and labor productivity. 
Table C1: Probability of Attaining Comparative Advantage, South Korea v. Other Countries, Post1972

\begin{tabular}{|c|c|c|c|c|c|c|c|c|}
\hline & \multicolumn{8}{|c|}{ Probability of RCA > 1} \\
\hline & \multicolumn{4}{|c|}{ Estimates with OLS } & \multicolumn{4}{|c|}{ Estimates with PPML } \\
\hline & Full Sample & Full Sample & Similar Income & Same Income & Full Sample & Full Sample & Similar Income & Same Income \\
\hline & 1 & 2 & 3 & 4 & 5 & 6 & 7 & 8 \\
\hline \multirow[t]{2}{*}{ Korea } & $0.131^{* * *}$ & $0.093^{* * *}$ & $0.138^{* * *}$ & $0.119^{* * *}$ & $1.013^{* * *}$ & $0.933^{* * *}$ & $1.106^{* * *}$ & $0.865^{* * *}$ \\
\hline & $(0.011)$ & $(0.013)$ & $(0.011)$ & $(0.021)$ & $(0.144)$ & $(0.090)$ & $(0.149)$ & $(0.218)$ \\
\hline \multirow[t]{2}{*}{ Gdp Pc } & & $0.046^{* * *}$ & & & & $0.675^{* * *}$ & & \\
\hline & & $(0.008)$ & & & & $(0.073)$ & & \\
\hline Industry Effect & Yes & Yes & Yes & Yes & Yes & Yes & Yes & Yes \\
\hline Year Effect & Yes & Yes & Yes & Yes & Yes & Yes & Yes & Yes \\
\hline R-Squared & 0.029 & 0.095 & 0.074 & 0.101 & 0.046 & 0.163 & 0.114 & 0.112 \\
\hline Observations & 251160 & 251160 & 76440 & 24570 & 251160 & 251160 & 74340 & 21195 \\
\hline Mean of Dependent Variable & 0.076 & 0.076 & 0.073 & 0.100 & 0.076 & 0.076 & 0.075 & 0.116 \\
\hline Clusters (Countries-Products) & $92 \times 182$ & $92 \times 182$ & $28 \times 182$ & $9 \times 182$ & $92 \times 182$ & $92 \times 182$ & $28 \times 177$ & $9 \times 157$ \\
\hline
\end{tabular}




\section{Figure C1: Robustness - Triple Difference Estimations of Korean HCI on Industrial Development (Coarse UNIDO Data)}

A) Value Added

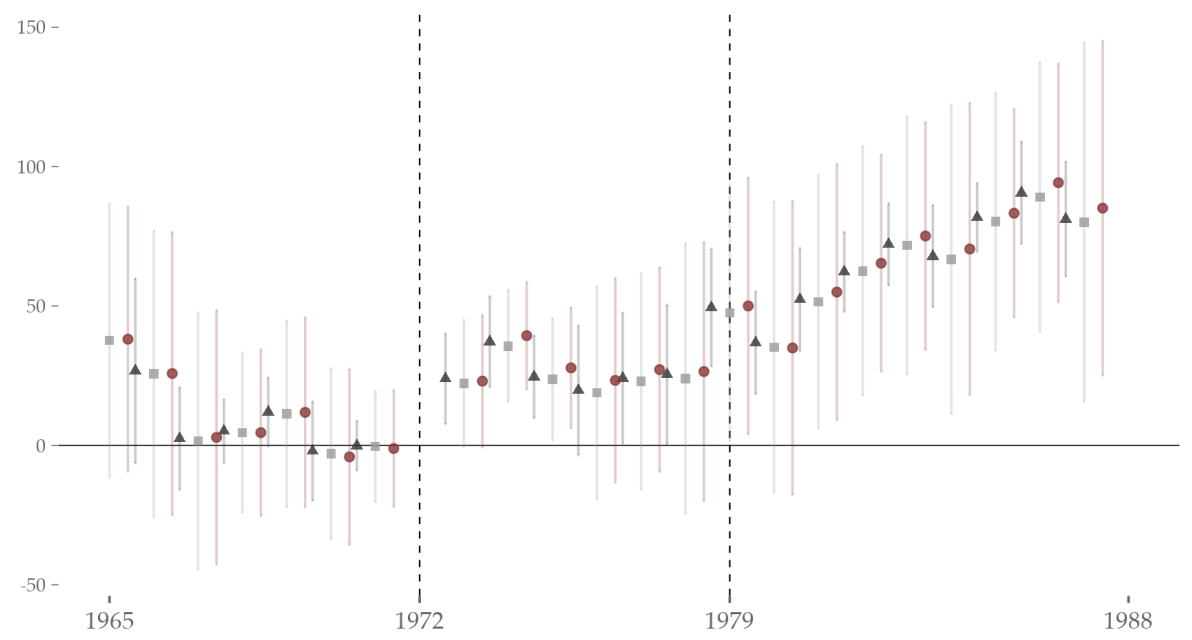

B) Total Employment

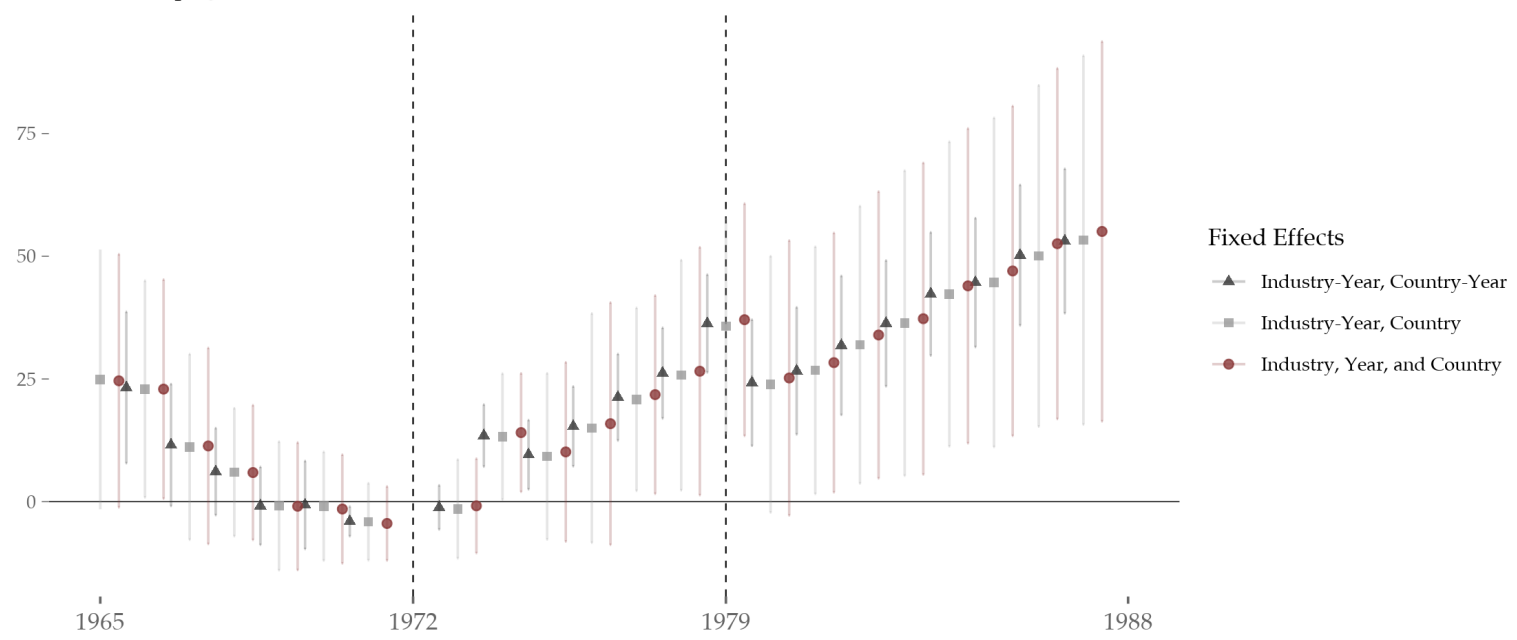

C) Labor Productivity (A/B)

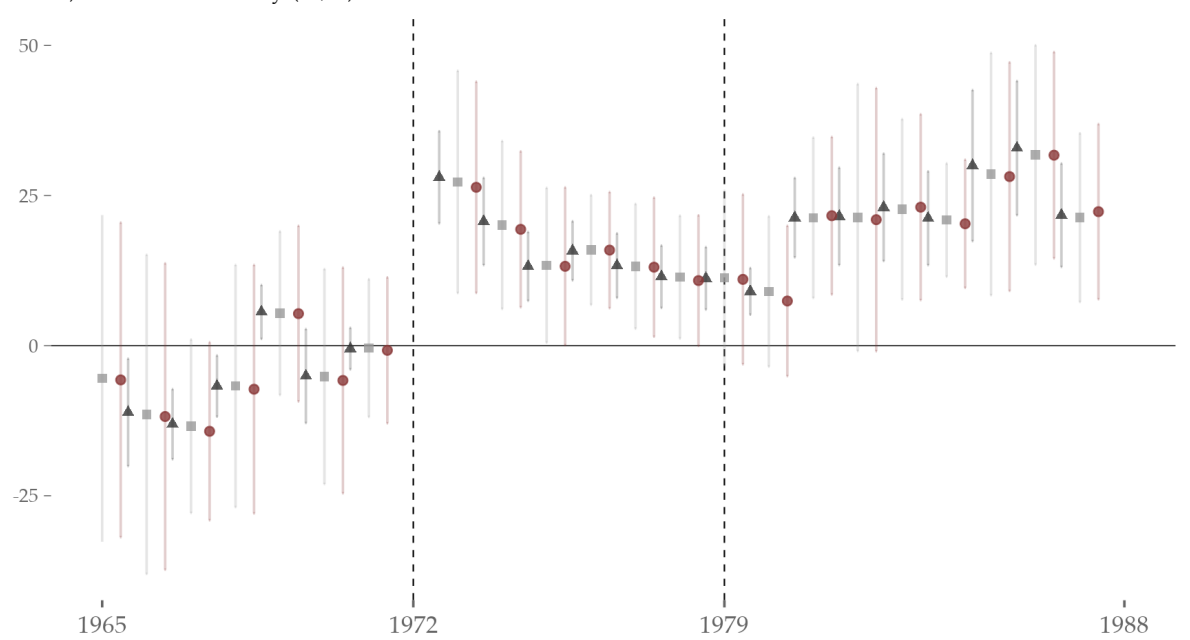

Note: Figure shows dynamic triple difference (DDD). for the main triple interaction coefficient. Figure plots main triple difference interactions (Treated X Korea X Year) for the impact of HCI on ISIC 2 digit-level UNIDO data. Fixed effects included in the model are shown in the legend. UNIDO estimates use standard OLS estimator. All specifications use twoway clustering at the country and product level. Figure plots coefficients of interest from intereaction of interest: HCI x Year x Korea. Estimates are relative to 1972, the year before the HCI policy intervention. The line at 1973 is the start of the policy. The line at 1979 demarcates the fall of the Park regime. Standard errors are clustered at the industry-level and corrected for heteroskedasticity. Confidence bands are in light grey and correspond to 95 percent confidence intervals. 
Figure D1: Input Use and High v. Low MRPK, During the HCI Period
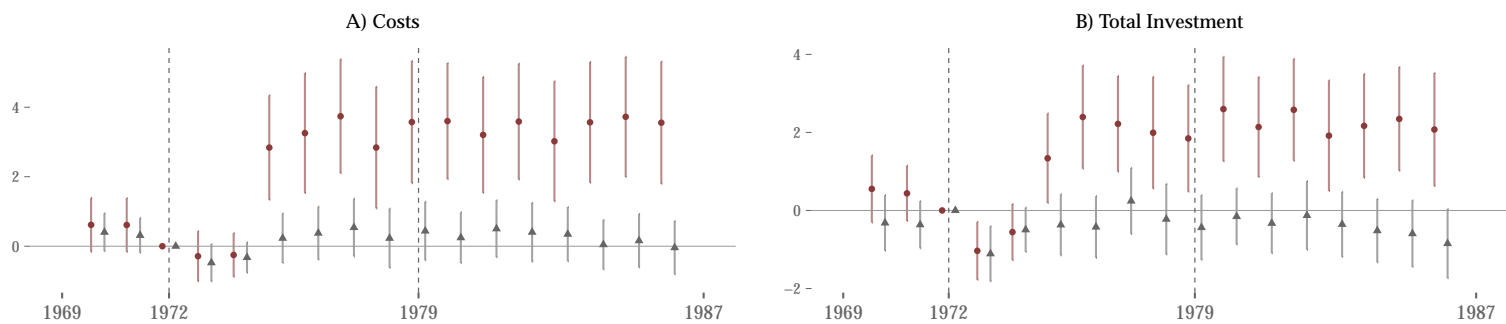

C) Output (Shipments)
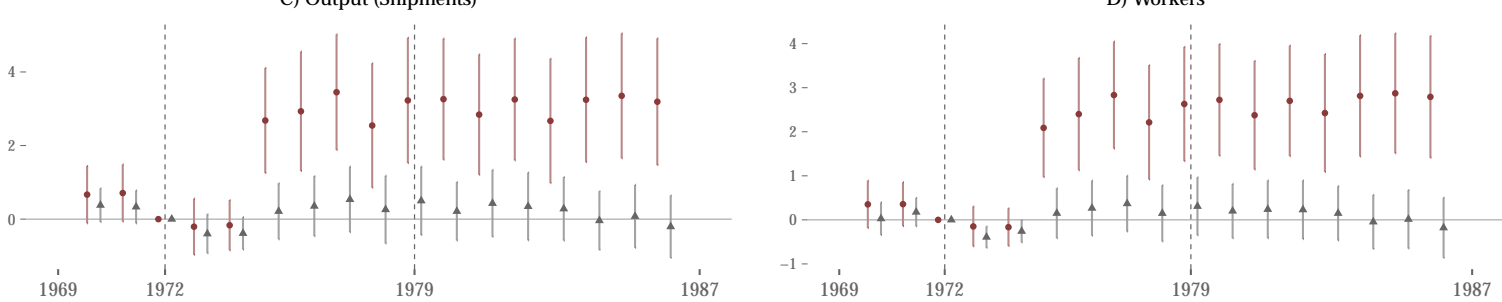

$\rightarrow$ HCI

$\unlhd$ Non-HCl

Note: Figure shows dynamic differences-in-differences estimates for the relationship between HCI and responses to investment incentives by pre-treatment, marginal revenue product of capital (MRPK). For industries above the pre-1972 median of MRPK. See text for calculation of MRPK. Regression estimates are shown separately for HCI (red) and Non-HCI (grey) industry. The top row should outcomes more directly related to MRPK, investment and materials. The bottom row shows development outcomes, real output shipped and workers. Coefficents are from the DD interaction, Year x MRPK, and estimated using OLS with two-way fixed effects (industry and year). Figure plots coefficients of interest from intereaction of interest: HCI x Year. Estimates are relative to 1972, the year before the HCI policy intervention. The line at 1972 is the start of the policy. The line at 1979 demarcates the fall of the Park regime. Standard errors are clustered at the industry-level and corrected for heteroskedasticity. Confidence bands are in light grey and correspond to 95 percent confidence intervals. 
Figure D2: Investment Across HCI and non-HCI Industry.

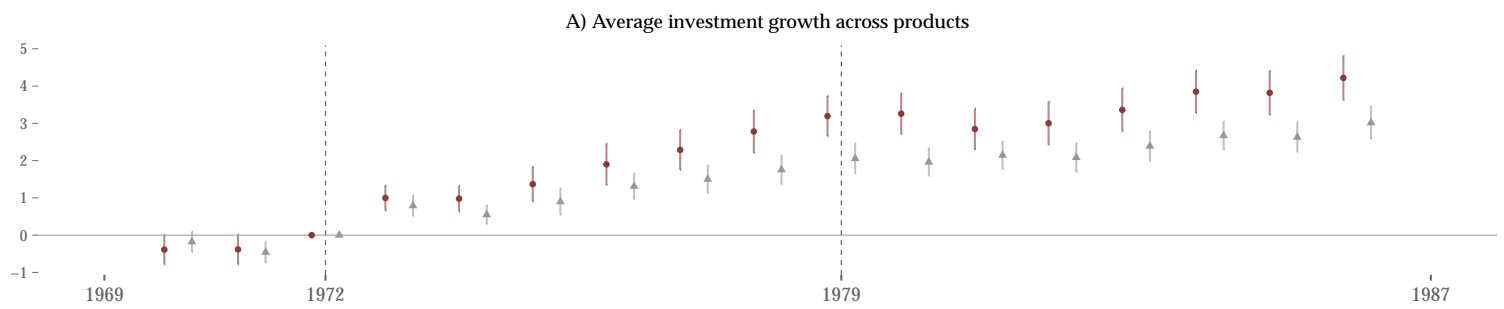

B) Interaction with pre-treatment capital intensity

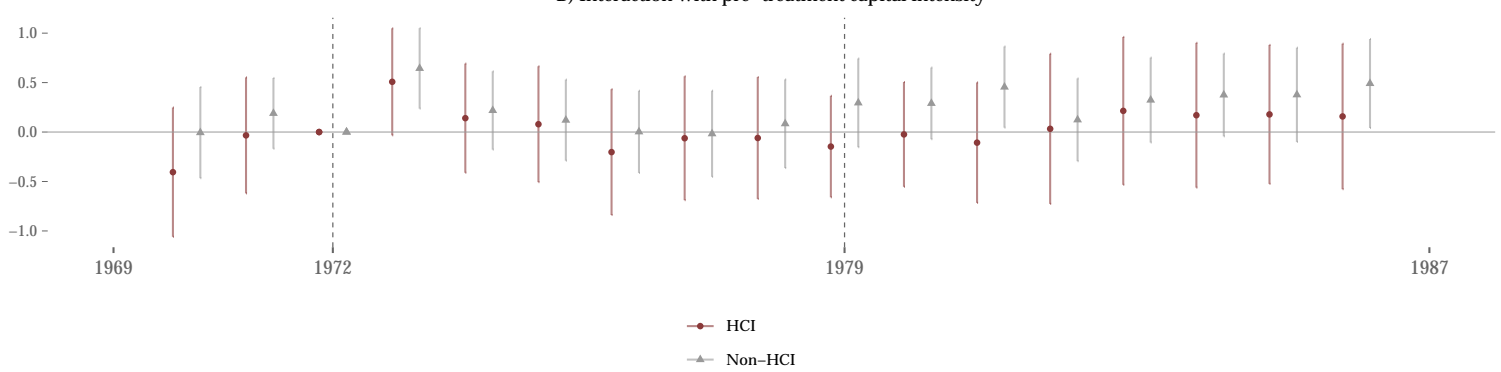

Note: Figure shows dynamic differences-in-differences estimates for the relationship between HCI and responses to investment incentives. Panel (A) shows the changes in investment for HCI and non-HCI industry, relative to 1972. Regressions are performed on either the HCI-only or non-HCI samples, and investment outcomes are regressed on leads and lags. Panel plots the leads and lags from this regression. Panel (B) shows investment growth by capital intensity, estimated separately by HCI and non-HCI industries. Coefficients are from the interaction Year x Capital Intensity, with 1972 as the omitted category. Pre-treatment capital intensity is measured as the pre-1973 levels of capital stock, divided by numbers of workers (asinh). Figure plots coefficients of interest from intereaction of interest: HCI x Year. Estimates are relative to 1972, the year before the HCI policy intervention. The line at 1972 is the start of the policy. The line at 1979 demarcates the fall of the Park regime. Standard errors are clustered at the industry-level and corrected for heteroskedasticity. Confidence bands are in light grey and correspond to 95 percent confidence intervals. 
Figure D3: Changes in Distribution of Trade Policies, HCI v. Non-HCI, 1968-1982

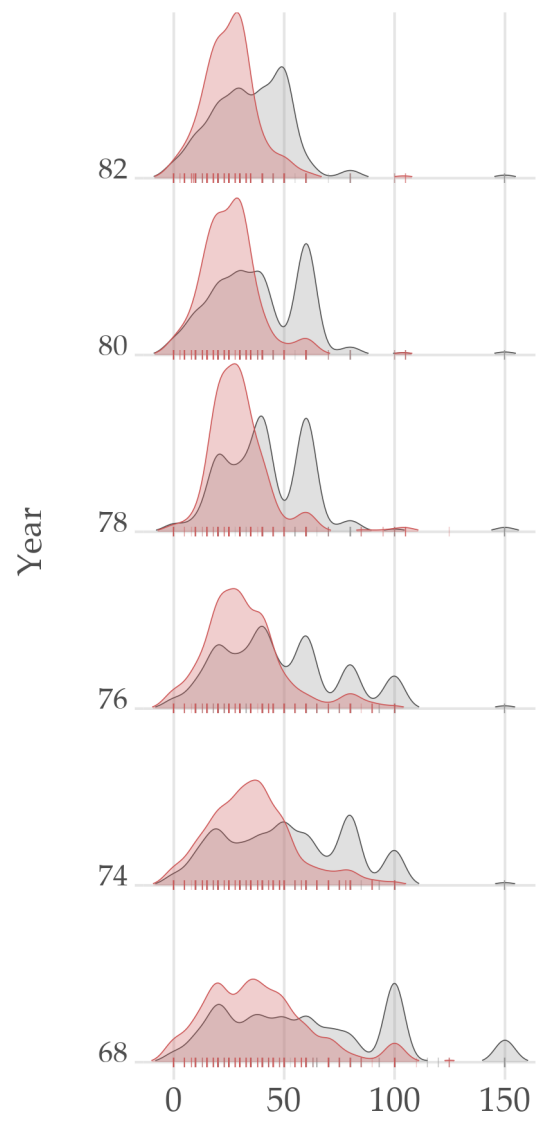

Nominal Tariff Rates (Percent)

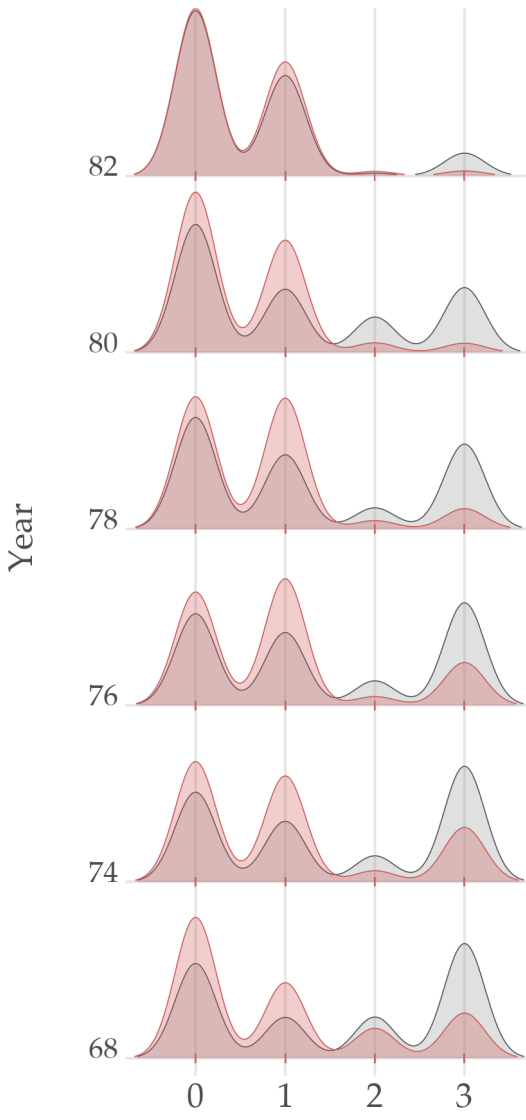

Quant. Restriction (0-3)

\section{Non-HCI HCI}

Notes: Figure shows the decline and convergence in (A) nominal tariff rates (percent) and (B) quantitative restrictions (severity scores 0-3). The kernal dentsity distribution for HCI products is in red; non-HCI products are in gray. Distributions are estimated over annual product-level data (unweighted, CCCN code level) for years 1968, 1974, 1978, 1980, and 1982. Data from Luedde-Neurath (1986), who coded the severity of quantitative restriction within 4-digit products using a 0-3 scale, from no restrictions (0) to severe (3). Kernel density bandwidths are 4.6 percent and 0.229 for tariffs and QR, respectively. 
Table D1: Robustness to TFP Estimate - Micro Evidence of Firm and Industry-Level Learning, HCI v. Non-HCI Industry, 1980-1986

\begin{tabular}{|c|c|c|c|c|c|}
\hline & \multicolumn{5}{|c|}{ Outcome: TFP (Alternive measures) } \\
\hline & $\mathrm{ACF}$ & LP & $\mathrm{OP}$ & OLS & W \\
\hline & 1 & 2 & 3 & 4 & 5 \\
\hline \multirow[t]{2}{*}{ Experience } & $0.406^{* * *}$ & $0.311^{* * *}$ & $0.364^{* * *}$ & $0.345^{* * *}$ & $0.360^{* * *}$ \\
\hline & $(0.012)$ & $(0.016)$ & $(0.011)$ & $(0.012)$ & $(0.014)$ \\
\hline \multirow[t]{2}{*}{ Experience (Industry) } & $0.019^{*}$ & $0.050^{* * *}$ & 0.016 & $0.037^{* * *}$ & $0.041^{* * *}$ \\
\hline & $(0.008)$ & $(0.011)$ & $(0.009)$ & $(0.009)$ & $(0.012)$ \\
\hline \multirow[t]{2}{*}{ Hci X Experience } & $0.033^{* * *}$ & $0.031^{*}$ & 0.018 & $0.026^{*}$ & $0.035^{*}$ \\
\hline & $(0.010)$ & $(0.014)$ & $(0.009)$ & $(0.011)$ & $(0.014)$ \\
\hline \multirow[t]{2}{*}{ Hci X Experience (Industry) } & $0.071^{* * *}$ & $0.112^{* * *}$ & -0.010 & $0.096^{* * *}$ & $0.125^{* * *}$ \\
\hline & $(0.016)$ & $(0.020)$ & $(0.012)$ & $(0.015)$ & $(0.021)$ \\
\hline \multirow[t]{2}{*}{ Capital Per Worker } & $-0.062^{* * *}$ & $-0.042^{* * *}$ & $-0.101^{* * *}$ & $-0.043^{* * *}$ & $-0.024^{* * *}$ \\
\hline & $(0.005)$ & $(0.005)$ & $(0.006)$ & $(0.006)$ & $(0.005)$ \\
\hline \multirow[t]{2}{*}{ Materials Per Worker } & $-0.077^{* * *}$ & -0.007 & $-0.066^{* * *}$ & $-0.047^{* * *}$ & $-0.029^{*}$ \\
\hline & $(0.010)$ & $(0.013)$ & $(0.010)$ & $(0.011)$ & $(0.013)$ \\
\hline \multirow[t]{2}{*}{ Skill Ratio } & $0.132^{* *}$ & 0.026 & 0.014 & $0.193^{* *}$ & -0.035 \\
\hline & $(0.047)$ & $(0.055)$ & $(0.027)$ & $(0.066)$ & $(0.051)$ \\
\hline \multirow[t]{2}{*}{ Invest. Per Worker } & $0.182^{* * *}$ & $0.266^{* * *}$ & $0.177^{* * *}$ & $0.228^{* * *}$ & $0.236^{* * *}$ \\
\hline & $(0.009)$ & $(0.011)$ & $(0.008)$ & $(0.010)$ & $(0.011)$ \\
\hline Plant Effect & Yes & Yes & Yes & Yes & Yes \\
\hline Year Effect & Yes & Yes & Yes & Yes & Yes \\
\hline R-Squared & 0.577 & 0.669 & 0.504 & 0.605 & 0.642 \\
\hline Observations & 237334 & 237334 & 237334 & 237334 & 237334 \\
\hline Clusters (Industry And Plant) & $490 \times 58245$ & $490 \times 58245$ & $490 \times 58245$ & $490 \times 58245$ & $490 \times 58245$ \\
\hline \multirow[t]{2}{*}{ Linear Combination (Firm-Level) } & 0.439 & 0.342 & 0.383 & 0.371 & 0.395 \\
\hline & $(0.012)$ & $(0.018)$ & $(0.013)$ & $(0.015)$ & $(0.017)$ \\
\hline \multirow[t]{2}{*}{ Linear Combination (Industry-Level) } & 0.090 & 0.162 & 0.006 & 0.134 & 0.166 \\
\hline & $(0.015)$ & $(0.017)$ & $(0.009)$ & $(0.012)$ & $(0.018)$ \\
\hline
\end{tabular}

Note:

The relationship between TFP and measures of experience (cumulative output per worker). TFP is estimatied using OLS, Olley-Pakes (OP), Levinsohn-Petrin (LP), Ackerberg et al. (ACF), and Wooldridge's method (W). Experience is plant-level cumulative learning and Experience (Industry) is industry-level spillovers. Standard errors are clustered at the industry-level and corrected for heteroskedasticity. ${ }^{*}$ Significant at the 10 percent level. ${ }^{* *}$ Significant at the 5 percent level. ${ }^{* *}$ Significant at the 1 percent level.

* Source - Mining and Manufacturing Survey and Mining and Manufacturing Census. 1980-1986 
Table D2: Relationship Between Policy and Growth

\begin{tabular}{|c|c|c|c|c|c|c|c|c|c|}
\hline & Growth Value Add. & Growth Value Add. & Growth Value Add. & Growth Employment & Growth Employment & Growth Employment & Growth Labor Prod. & Growth Labor Prod. & Growth Labor Prod. \\
\hline & 1 & 2 & 3 & 4 & 5 & 6 & 7 & 8 & 9 \\
\hline \multirow[t]{2}{*}{ Growth Invest. Total } & $0.139^{* * * *}$ & 0.063 & $0.106^{* *}$ & $0.147^{* * * *}$ & $0.120^{* * *}$ & $0.129^{* * *}$ & -0.008 & $-0.057^{*}$ & -0.023 \\
\hline & $(0.030)$ & $(0.046)$ & $(0.029)$ & $(0.023)$ & $(0.030)$ & $(0.021)$ & $(0.015)$ & $(0.025)$ & $(0.016)$ \\
\hline \multirow[t]{2}{*}{ Growth Tariff } & $-0.472^{* *}$ & $-0.348^{*}$ & $-0.434^{* * *}$ & $-0.336^{*}$ & -0.272 & $-0.315^{* *}$ & -0.136 & -0.076 & -0.119 \\
\hline & $(0.158)$ & $(0.153)$ & $(0.098)$ & $(0.159)$ & $(0.141)$ & $(0.109)$ & $(0.081)$ & $(0.107)$ & $(0.104)$ \\
\hline \multirow{2}{*}{ Growth Qr } & 0.093 & 0.177 & 0.030 & 0.068 & 0.168 & 0.033 & 0.025 & 0.009 & -0.004 \\
\hline & $(0.165)$ & $(0.167)$ & $(0.100)$ & $(0.078)$ & $(0.106)$ & $(0.060)$ & $(0.123)$ & $(0.113)$ & $(0.094)$ \\
\hline \multirow{2}{*}{ Growth Qr Input } & 0.276 & 0.026 & 0.223 & 0.179 & -0.000 & 0.150 & 0.097 & 0.026 & 0.072 \\
\hline & $(0.489)$ & $(0.408)$ & $(0.327)$ & $(0.300)$ & $(0.247)$ & $(0.245)$ & $(0.245)$ & $(0.219)$ & $(0.163)$ \\
\hline \multirow[t]{2}{*}{ Growth Tariff Input } & -0.154 & $-0.578^{*}$ & $-0.395^{*}$ & -0.065 & -0.302 & -0.196 & -0.089 & -0.276 & -0.198 \\
\hline & $(0.154)$ & $(0.260)$ & $(0.181)$ & $(0.114)$ & $(0.188)$ & $(0.123)$ & $(0.100)$ & $(0.193)$ & $(0.123)$ \\
\hline Growth Experience & & & $1.585^{* * *}$ & & & $0.864^{* * *}$ & & & $0.721^{* *}$ \\
\hline Industry Effect & No & Yes & $\begin{array}{l}(0.298) \\
\text { No }\end{array}$ & No & Yes & $\begin{array}{l}(0.215) \\
\text { No }\end{array}$ & No & Yes & $\begin{array}{l}(0.222) \\
\text { No }\end{array}$ \\
\hline Period Effect & Yes & Yes & Yes & Yes & Yes & Yes & Yes & Yes & Yes \\
\hline R-Squared & 0.287 & 0.467 & 0.570 & 0.299 & 0.427 & 0.508 & 0.249 & 0.476 & 0.423 \\
\hline Observations & 123 & 123 & 123 & 123 & 123 & 123 & 123 & 123 & 123 \\
\hline Clusters & 33 & 33 & 33 & 33 & 33 & 33 & 33 & 33 & 33 \\
\hline
\end{tabular}

The relationship between annualized growth in growth outcomes and policy related variables. All variables are annualized log growth. Standard errors are clustered at the industry-level and corrected for heteroskedasticity. * Significant at the 10 percent level. * Significant at the 5 percent level. ${ }^{* * *}$ Significant at the 1 percent level.

Source - Mining and Manufacturing Survey and Mining and Manufacturing Census: 1970-1986. 
Figure E1: Top 20 Non-HCI Sectors with Highest Forward and Backward (Direct) Linkages to Targeted Industry

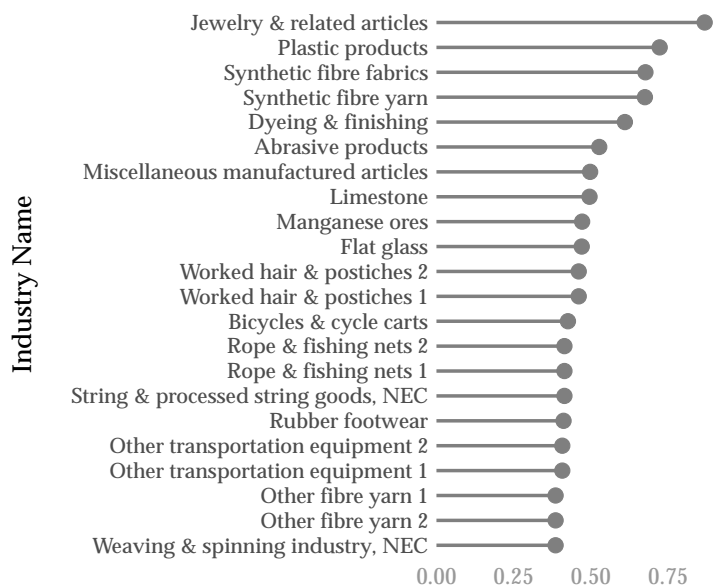

Share Forward Linkages

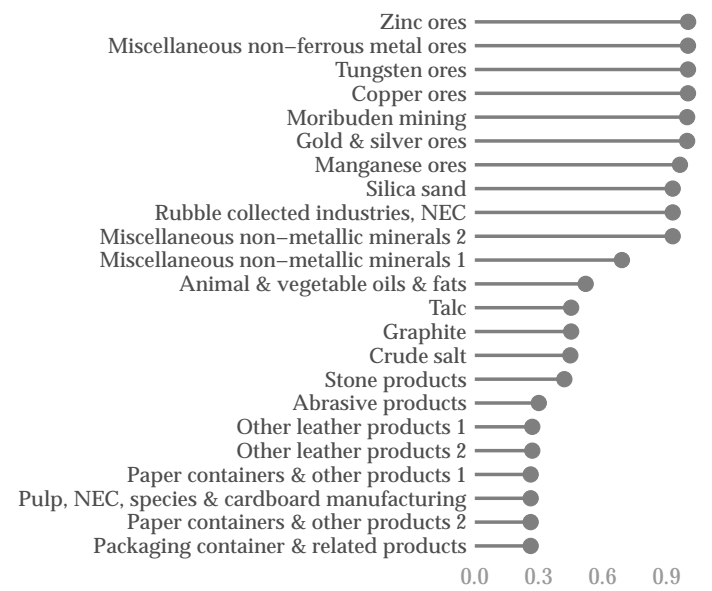

Share Backward Linkages

Notes: Figure shows the top-ranked manufacturing industries in terms of backward linkages and forward linkages to targeted industries. Both forward and backward linkages are oriented in terms of the treated sector. Share Backward Linkage measures the weighted share of output from a non-HCI industry being sold to an $\mathrm{HCI}$ industry. Whereas, Share Forward Linkage measures the weighted share inputs a non-HCI industry sources from HCI industry. See text for definitions of weights. Both measures are direct I- 0 flows, and are calculated from the 1970 Bank of Korea inputoutput tables. 
Figure E2: Targeted Sectors and Non-Targeted Sectors in the 1970 Korean Industrial Network, Weighted by Number of Outward Connections (Forward Linkages) to Downstream Sectors

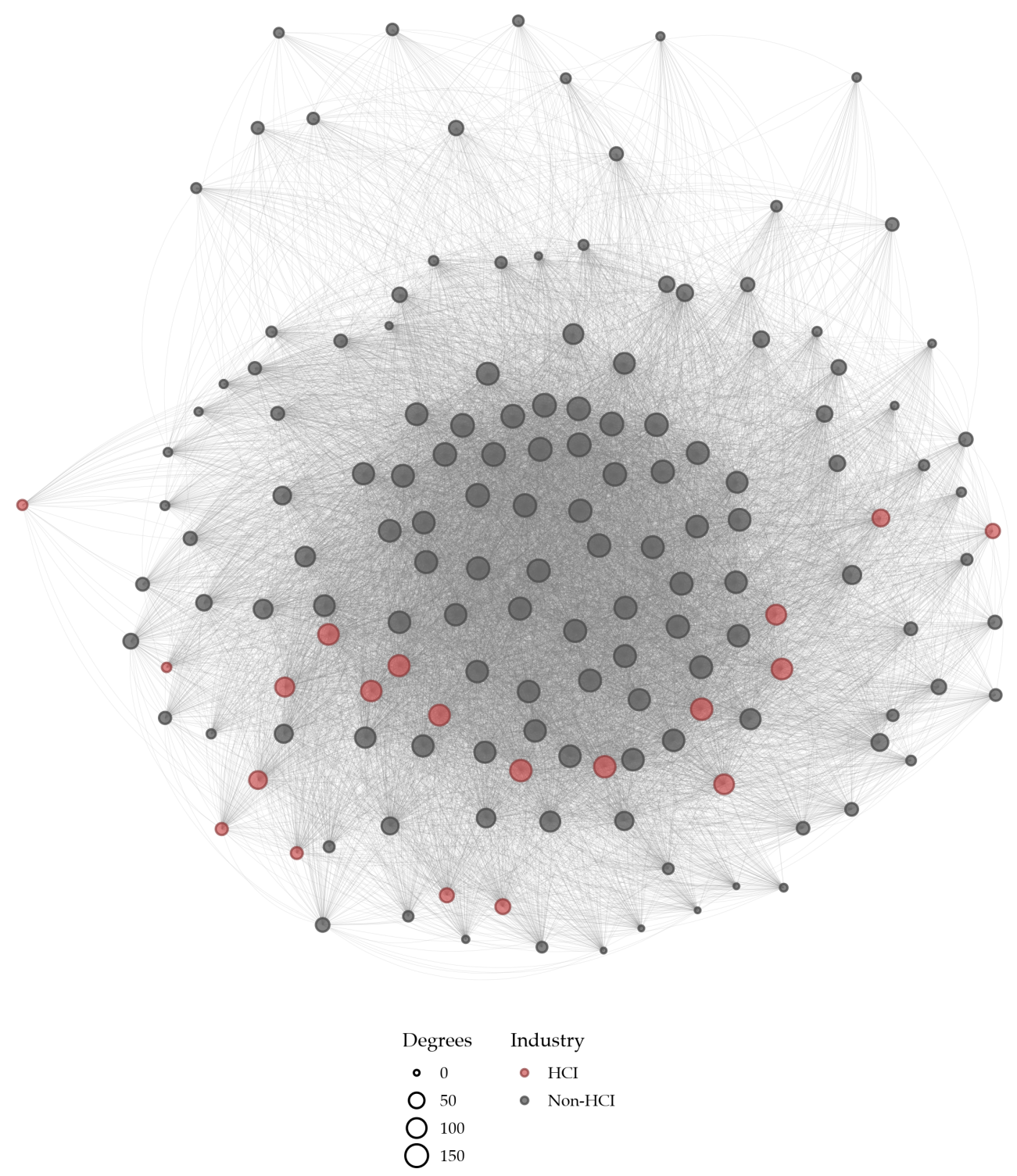

Notes: Figure above shows network diagram of HCI (red) and non-HCI sectors (gray). Nodes are industries, and gray network links (or 'edges') indicate a linkages between sector that sell output to downstream buyers. These are also called 'forward links.' The size each nodes reflects the raw number of outward links. Source: 1970 'medium' inputoutput tables, Bank of Korea. 
Table F1: Average Impact of Total (Leontief) Linkages on Output, Before and After 1973

\begin{tabular}{|c|c|c|c|c|c|c|c|c|}
\hline & \multicolumn{8}{|c|}{ Outcome - Real value added (ihs) } \\
\hline & \multicolumn{4}{|c|}{ Panel A) 5-Digit Panel, 1970 - 1986} & \multicolumn{4}{|c|}{ Panel B) 4-Digit Panel, 1967 - 1986} \\
\hline & \multicolumn{2}{|c|}{ Full Sample } & \multicolumn{2}{|c|}{ Non-HCI Sample } & \multicolumn{2}{|c|}{ Full Sample } & \multicolumn{2}{|c|}{ Non-HCI Sample } \\
\hline & 1 & 2 & 3 & 4 & 1 & 2 & 3 & 4 \\
\hline \multirow[t]{2}{*}{ Post X Forward Link } & 0.646 & 0.623 & $1.784^{*}$ & 1.577 & $1.407^{*}$ & $1.588^{* *}$ & $2.926^{*}$ & $3.515^{* *}$ \\
\hline & $(0.410)$ & $(0.435)$ & $(0.847)$ & $(0.873)$ & $(0.585)$ & $(0.597)$ & $(1.287)$ & $(1.254)$ \\
\hline \multirow[t]{2}{*}{ Post X Backward Link } & -0.0687 & -0.0399 & 0.0379 & 0.0691 & -1.071 & -1.093 & -2.193 & -1.898 \\
\hline & $(0.327)$ & $(0.328)$ & $(0.357)$ & $(0.358)$ & $(0.592)$ & $(0.553)$ & $(1.582)$ & $(1.412)$ \\
\hline Industry Fe & Yes & Yes & Yes & Yes & Yes & Yes & Yes & Yes \\
\hline Year Fe & Yes & Yes & Yes & Yes & Yes & Yes & Yes & Yes \\
\hline Targeted X Year & Yes & Yes & No & No & Yes & Yes & No & No \\
\hline Network Controls & No & Yes & No & Yes & No & Yes & No & Yes \\
\hline R-Squared & 0.764 & 0.765 & 0.751 & 0.754 & 0.838 & 0.841 & 0.812 & 0.816 \\
\hline Observations & 4726 & 4726 & 2992 & 2992 & 1760 & 1760 & 1100 & 1100 \\
\hline Clusters & 278 & 278 & 176 & 176 & 88 & 88 & 55 & 55 \\
\hline
\end{tabular}

Note:

Average differences-in-differences estimates, before and after 1973. Regressions interact linkage measure with Post 1973 indicator. For these estimates, both linkage interactions are shown (forward and backward); whereas, dynamic estimates presented only linkages for the interaction of interest (forward or backward). Standard errors are clustered at the industry-level and corrected for heteroskedasticity. * Significant at the 10 percent level. ${ }^{* *}$ Significant at the 5 percent level. ${ }^{* *}$ Significant at the 1 percent level.

* Source for Panel A - Mining and Manufacturing Survey and Mining and Manufacturing Census: 1970-1986.

${ }^{\dagger}$ Source for Panel B - Mining and Manufacturing Survey and Mining and Manufacturing Census: 1967-1986.

Table F2: Average Impact of Leontief Linkages on Output Prices, Before and After 1973

\begin{tabular}{|c|c|c|c|c|c|c|c|c|}
\hline & \multicolumn{8}{|c|}{ Outcome - Output prices (ihs) } \\
\hline & \multicolumn{4}{|c|}{ Panel A) 5-Digit Panel, 1970 - 1986} & \multicolumn{4}{|c|}{ Panel B) 4-Digit Panel, 1967 - 1986} \\
\hline & \multicolumn{2}{|c|}{ Full Sample } & \multicolumn{2}{|c|}{ Non-HCI Sample } & \multicolumn{2}{|c|}{ Full Sample } & \multicolumn{2}{|c|}{ Non-HCI Sample } \\
\hline & 1 & 2 & 3 & 4 & 1 & 2 & 3 & 4 \\
\hline \multirow[t]{2}{*}{ Post $X$ Forward Link } & $-0.170^{* *}$ & $-0.173^{* *}$ & $-0.341^{* * *}$ & $-0.340^{* * *}$ & $-0.389^{*}$ & $-0.398^{*}$ & $-0.720^{* *}$ & $-0.718^{* *}$ \\
\hline & $(0.0531)$ & $(0.0544)$ & $(0.0969)$ & $(0.0967)$ & $(0.155)$ & $(0.154)$ & $(0.237)$ & $(0.224)$ \\
\hline \multirow[t]{2}{*}{ Post X Backward Link } & $0.112^{* * * *}$ & $0.101^{* * *}$ & $0.0952^{* * *}$ & $0.0836^{* * *}$ & $0.338^{*}$ & $0.327^{*}$ & $0.693^{* *}$ & $0.654^{* * *}$ \\
\hline & $(0.0241)$ & $(0.0235)$ & $(0.0230)$ & $(0.0220)$ & $(0.159)$ & $(0.154)$ & $(0.251)$ & $(0.245)$ \\
\hline Industry Fe & Yes & Yes & Yes & Yes & Yes & Yes & Yes & Yes \\
\hline Year Fe & Yes & Yes & Yes & Yes & Yes & Yes & Yes & Yes \\
\hline Targeted X Year & Yes & Yes & No & No & Yes & Yes & No & No \\
\hline Network Controls & No & Yes & No & Yes & No & Yes & No & Yes \\
\hline R-Squared & 0.952 & 0.954 & 0.937 & 0.939 & 0.957 & 0.958 & 0.952 & 0.954 \\
\hline Observations & 4722 & 4722 & 2988 & 2988 & 1751 & 1751 & 1097 & 1097 \\
\hline Clusters & 278 & 278 & 176 & 176 & 88 & 88 & 55 & 55 \\
\hline
\end{tabular}

Note:

Average differences-in-differences estimates, before and after 1973. Regressions interact linkage measure with Post 1973 indicator. For these estimates, both linkage interactions are shown (forward and backward); whereas, dynamic estimates presented only linkages for the interaction of interest (forward or backward). Standard errors are clustered at the industry-level and corrected for heteroskedasticity. ${ }^{*}$ Significant at the 10 percent level. ** Significant at the 5 percent level. *** Significant at the 1 percent level.

* Source for Panel A - Mining and Manufacturing Survey and Mining and Manufacturing Census: 1970-1986.

† Source for Panel B - Mining and Manufacturing Survey and Mining and Manufacturing Census: 1967-1986. 
Figure F1: Direct Forward Linkages and Development Outcomes
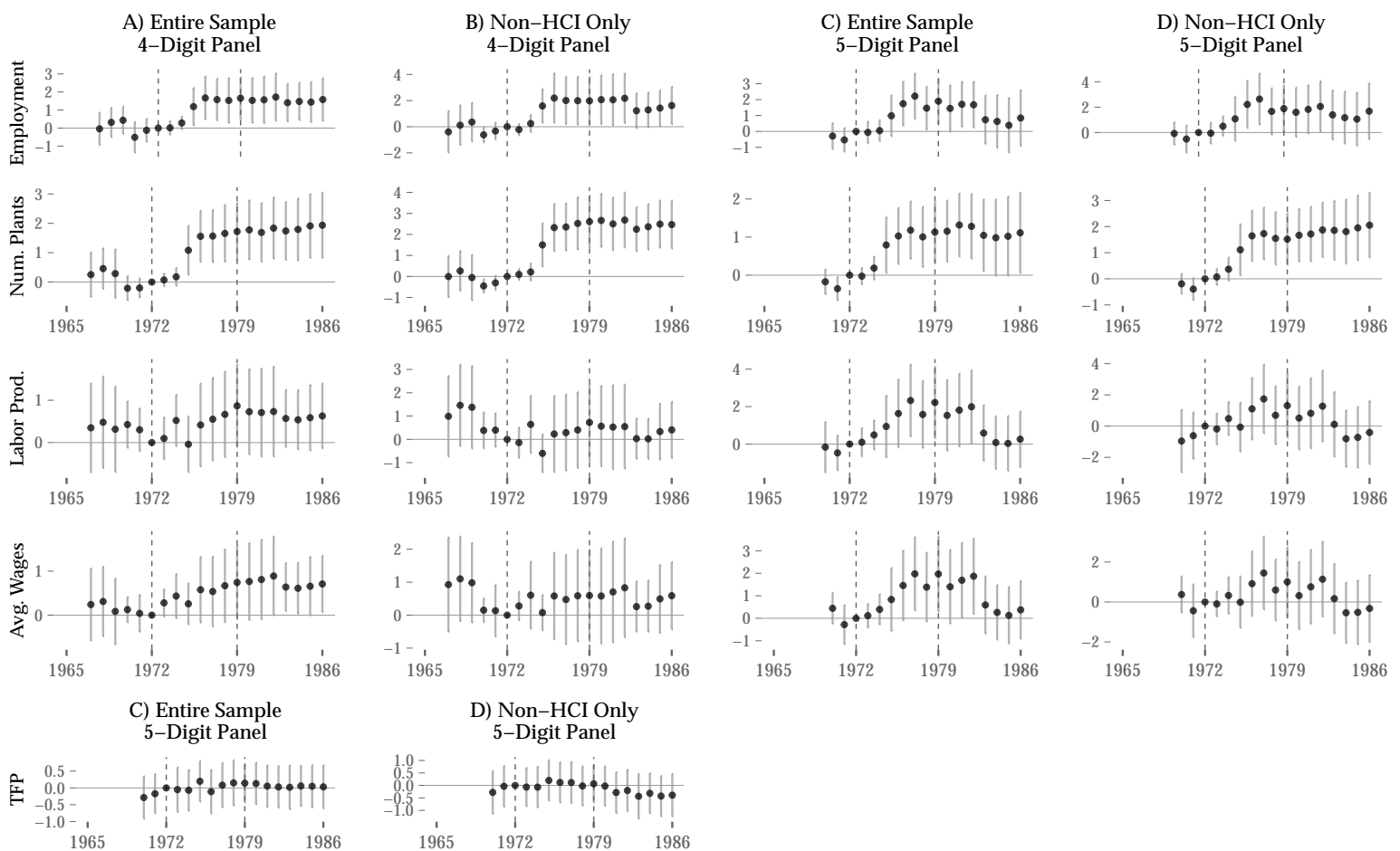

Notes: Figures plot dynamic differences-in-differences estimates for the relationship between direct forward linkage exposure to HCI and outcomes: workers, establishments, labor productivity, avg wages, and TFP (ACF). All but TFP are IHS normalized. Estimates are relative to 1972, the year before HCI. The year 1979 corresponds to collapse of Park regime. Years are on the x-axis. Estimates for the effect of direct forward linkages effects (Linkage X Year) are on the y-axis. Linkage exposure is calculated from weighted sum of exposure through IO network; see text for details. Panels (A) and (C) show estimates for the entire sample of industries, controlling the effect of direct targeting, $\mathrm{HCI} x$ Year. Panels (B) and (D) shows estimates for only non-targeted industry. Regressions include controls for direct backward linkage connections, interacted with time. 95 percent confidence intervals are shown in gray. 
Table F3: Average Impact of Direct Linkages on Industrial Development Outcomes, Before and After 1973

\begin{tabular}{|c|c|c|c|c|c|c|c|c|c|c|c|c|c|c|c|c|c|c|}
\hline & \multicolumn{10}{|c|}{ A) 5-Digit Panel, 1970 - 1986} & \multicolumn{8}{|c|}{ B) 4-Digit Panel, 1967 - 1986} \\
\hline & \multicolumn{2}{|c|}{ Employment } & \multicolumn{2}{|c|}{ Num. Plants } & \multicolumn{2}{|c|}{ Labor Prod. } & \multicolumn{2}{|c|}{ TFP (ACF) } & \multicolumn{2}{|c|}{ Avg. Wage. } & \multicolumn{2}{|c|}{ Employment } & \multicolumn{2}{|c|}{ Num. Plants } & \multicolumn{2}{|c|}{ Labor Prod. } & \multicolumn{2}{|c|}{ Avg. Wage. } \\
\hline & Full & Non-HCI & Full & Non-HCI & Full & Non-HCI & Full & Non-HCI & Full & Non-HCI & Full & Non-HCI & Full & Non-HCI & Full & Non-HCI & Full & $\mathrm{Non}-\mathrm{HCl}$ \\
\hline & 1 & 2 & 3 & 4 & 5 & 6 & 7 & 8 & 9 & 10 & 1 & 2 & 3 & 4 & 5 & 6 & 7 & 8 \\
\hline Post $\mathrm{X}$ Forward Link & $1.397^{*}$ & $1.675^{*}$ & $1.120^{* *}$ & $1.689^{* * *}$ & 1.322 & 0.941 & 0.202 & -0.0184 & 0.977 & 0.392 & $1.320^{*}$ & $1.693^{*}$ & $1.367^{* *}$ & $2.166^{* * *}$ & 0.229 & -0.484 & 0.479 & -0.0546 \\
\hline & $(0.589)$ & $(0.823)$ & $(0.363)$ & $(0.459)$ & $(0.676)$ & $(0.843)$ & $(0.224)$ & $(0.223)$ & $(0.558)$ & $(0.637)$ & $(0.567)$ & $(0.782)$ & $(0.496)$ & $(0.534)$ & $(0.403)$ & $(0.533)$ & $(0.312)$ & $(0.445)$ \\
\hline Post X Backward Link & $-1.136^{*}$ & $\begin{array}{l}-1.186 \\
0661)\end{array}$ & $\begin{array}{l}-0.345 \\
0.277)\end{array}$ & -0.498 & $\begin{array}{l}-0.848 \\
0.567\end{array}$ & $\begin{array}{l}-0.681 \\
0.744)\end{array}$ & $-0.579^{*}$ & $-0.679^{*}$ & $\begin{array}{l}-0.963 \\
0.515)\end{array}$ & -0.805 & $\begin{array}{l}-0.535 \\
0.058\end{array}$ & $-1.230^{*}$ & 0.0890 & $\begin{array}{l}-0.582 \\
0.574)\end{array}$ & $-0.757^{*}$ & -0.820 & $-0.812^{*}$ & $\begin{array}{l}-0.795 \\
-0453)\end{array}$ \\
\hline & $(0.526)$ & $(0.661)$ & $(0.277)$ & $(0.334)$ & $(0.567)$ & $(0.744)$ & $(0.250)$ & $(0.283)$ & $(0.515)$ & $(0.676)$ & $(0.508)$ & $(0.602)$ & $(0.483)$ & $(0.574)$ & $(0.380)$ & $(0.490)$ & $\begin{array}{l}(0.313) \\
\text { Yes }\end{array}$ & $(0.453)$ \\
\hline Industry Fe & Yes & Yes & Yes & Yes & Yes & Yes & Yes & Yes & Yes & Yes & Yes & Yes & Yes & Yes & Yes & Yes & Yes & Yes \\
\hline Year Fe & Yes & Yes & Yes & Yes & Yes & Yes & Yes & Yes & Yes & Yes & Yes & Yes & Yes & Yes & Yes & Yes & Yes & Yes \\
\hline Targeted X Year & Yes & No & Yes & No & Yes & No & Yes & No & Yes & No & Yes & No & Yes & No & Yes & No & Yes & No \\
\hline Network Controls & Yes & Yes & Yes & Yes & Yes & Yes & Yes & Yes & Yes & Yes & Yes & Yes & Yes & Yes & Yes & Yes & Yes & Yes \\
\hline R-Squared & 0.786 & 0.796 & 0.857 & 0.864 & 0.630 & 0.598 & 0.866 & 0.841 & 0.634 & 0.598 & 0.849 & 0.846 & 0.887 & 0.888 & 0.764 & 0.725 & 0.757 & 0.713 \\
\hline Observations & 4726 & 2992 & 4726 & 2992 & 4726 & 2992 & 4297 & 2728 & 4726 & 2992 & 1760 & 1100 & 1760 & 1100 & 1760 & 1100 & 1760 & 1100 \\
\hline Clusters & 278 & 176 & 278 & 176 & 278 & 176 & 274 & 174 & 278 & 176 & 88 & 55 & 88 & 55 & 88 & 55 & 88 & 55 \\
\hline
\end{tabular}

Noterage differences-in-differences estimates, before and after 1973. Regressions interact linkage measure with Post 1973 indicator. For these estimates, both linkage interactions are shown (forward and backward): whereas, dynamic estimates presented only linkages for the interaction of interest (forward or backward). Standard errors are clustered at the industry-level and corrected for heteroskedasticity. * Significant at the 10 percent level. ** Significant at the 5 percent level. *** Significant at the 1 percent level.

* Source for Panel A - Mining and Manufacturing Survey and Mining and Manufacturing Census: 1970-1986.

${ }^{\dagger}$ Source for Panel B - Mining and Manufacturing Survey and Mining and Manufacturing Census: 1967-1986.

Table F4: Average Impact of Total (Leontief) Linkages on Industrial Development, Before and After 1973

\begin{tabular}{|c|c|c|c|c|c|c|c|c|c|c|c|c|c|c|c|c|c|c|}
\hline & \multicolumn{10}{|c|}{ A) 5-Digit Panel, 1970 - 1986} & \multicolumn{8}{|c|}{ B) 4-Digit Panel, 1967 - 1986} \\
\hline & \multicolumn{2}{|c|}{ Employment } & \multicolumn{2}{|c|}{ Num. Plants } & \multicolumn{2}{|c|}{ Labor Prod. } & \multicolumn{2}{|c|}{ TFP (ACF) } & \multicolumn{2}{|c|}{ Avg. Wage. } & \multicolumn{2}{|c|}{ Employment } & \multicolumn{2}{|c|}{ Num. Plants } & \multicolumn{2}{|c|}{ Labor Prod. } & \multicolumn{2}{|c|}{ Avg. Wage. } \\
\hline & Full & Non-HCI & Full & Non-HCI & Full & Non-HCI & Full & Non-HCI & Full & Non-HCI & Full & Non-HCI & Full & Non-HCI & Full & Non-HCI & Full & Non-HCI \\
\hline & 1 & 2 & 3 & 4 & 5 & 6 & 7 & 8 & 9 & 10 & 1 & 2 & 3 & 4 & 5 & 6 & 7 & 8 \\
\hline Post $X$ Forward Link & 0.414 & 1.236 & 0.283 & 0.872 & -0.0532 & 0.401 & $0.427^{*}$ & 0.300 & 0.0621 & 0.447 & $1.187^{*}$ & $3.544^{* *}$ & $0.860^{*}$ & $3.762^{* * *}$ & 0.463 & 0.286 & 0.684 & 0.959 \\
\hline & $(0.371)$ & $(0.688)$ & $(0.210)$ & $(0.510)$ & $(0.372)$ & $(0.641)$ & $(0.200)$ & $(0.236)$ & $(0.329)$ & $(0.541)$ & $(0.488)$ & $(1.088)$ & $(0.362)$ & $(0.764)$ & $(0.422)$ & $(0.886)$ & $(0.379)$ & $(0.677)$ \\
\hline Post X Backward Link & -0.0938 & 0.0414 & 0.0219 & 0.0861 & 0.261 & 0.348 & -0.122 & -0.197 & 0.0735 & 0.160 & $-0.807^{*}$ & -0.867 & -0.381 & 0.0694 & -0.449 & -1.125 & $-0.644^{*}$ & -1.297 \\
\hline & $(0.260)$ & $(0.271)$ & $(0.118)$ & $(0.124)$ & $(0.293)$ & $(0.321)$ & $(0.177)$ & $(0.208)$ & $(0.271)$ & $(0.296)$ & $(0.372)$ & $(0.835)$ & $(0.264)$ & $(0.496)$ & $(0.325)$ & $(0.912)$ & $(0.303)$ & $(0.846)$ \\
\hline Industry Fe & Yes & Yes & Yes & Yes & Yes & Yes & Yes & Yes & Yes & Yes & Yes & Yes & Yes & Yes & Yes & Yes & Yes & Yes \\
\hline Year Fe & Yes & Yes & Yes & Yes & Yes & Yes & Yes & Yes & Yes & Yes & Yes & Yes & Yes & Yes & Yes & Yes & Yes & Yes \\
\hline Targeted X Year & Yes & No & Yes & No & Yes & No & Yes & No & Yes & No & Yes & No & Yes & No & Yes & No & Yes & No \\
\hline Network Controls & Yes & Yes & Yes & Yes & Yes & Yes & Yes & Yes & Yes & Yes & Yes & Yes & Yes & Yes & Yes & Yes & Yes & Yes \\
\hline R-Squared & 0.784 & 0.795 & 0.856 & 0.863 & 0.628 & 0.598 & 0.866 & 0.840 & 0.632 & 0.597 & 0.850 & 0.850 & 0.886 & 0.891 & 0.764 & 0.726 & 0.758 & 0.719 \\
\hline Observations & 4726 & 2992 & 4726 & 2992 & 4726 & 2992 & 4297 & 2728 & 4726 & 2992 & 1760 & 1100 & 1760 & 1100 & 1760 & 1100 & 1760 & 1100 \\
\hline Clusters & 278 & 176 & 278 & 176 & 278 & 176 & 274 & 174 & 278 & 176 & 88 & 55 & 88 & 55 & 88 & 55 & 88 & 55 \\
\hline
\end{tabular}

Average differences-in-differences estimates, before and after 1973. Regressions interact linkage measure with Post 1973 indicator. For these estimates, both linkage interactions are shown (forward and backward); whereas, dynamic estimates presented only linkages for the interaction of interest (forward or backward). Standard errors are clustered at the industry-level and corrected for heteroskedasticity. * Significant at the 10 percent level. ** Significant at the 5 percent level. *** Significant at the 1 percent level.

* Source for Panel A - Mining and Manufacturing Survey and Mining and Manufacturing Census: 1970-1986.

${ }^{\dagger}$ Source for Panel B - Mining and Manufacturing Survey and Mining and Manufacturing Census: 1967-1986. 
Figure G1: Relationship Between Direct Backward Linkages on Upstream Output

A) Entire Sample,4-Digit

$\infty$
B) Non-HCI Only, 4-Digit

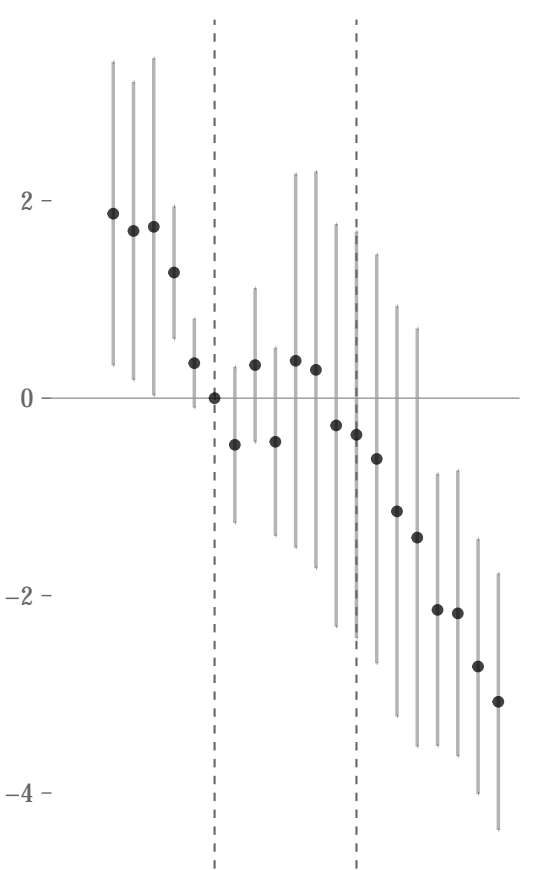

C) Entire Sample, 5-Digit

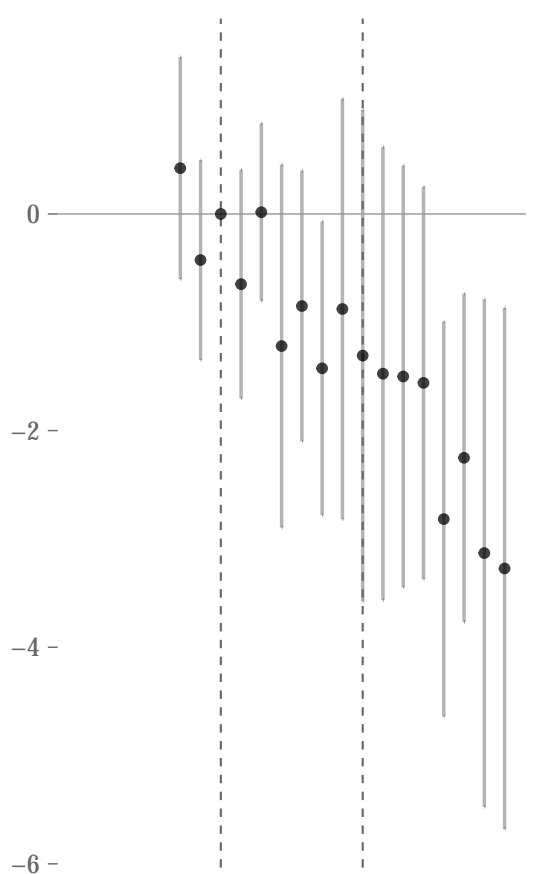

D) Non-HCI Only, 5-Digit

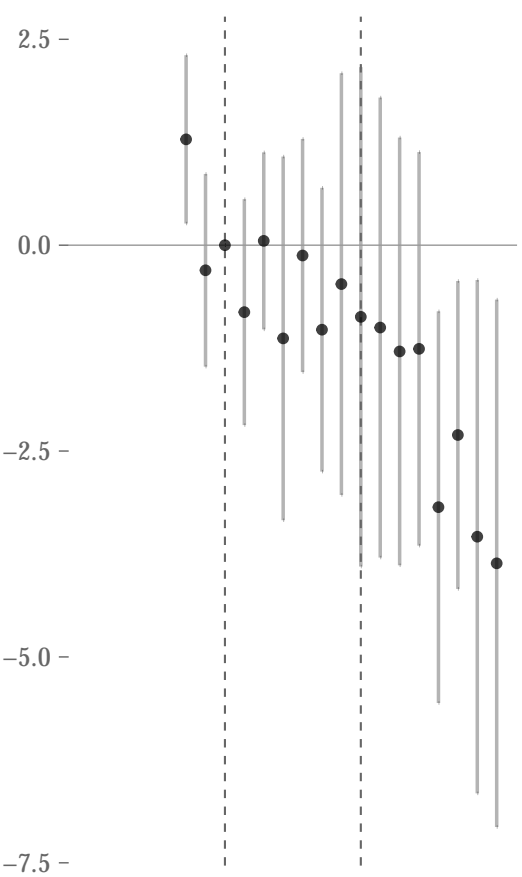

Notes: Figure plots dynamic differences-in-differences estimates for the relationship between direct backward linkage exposure to HCI and outcomes: real value added. Estimates are relative to, 1972, the year before HCI. The year 1979 corresponds to collapse of Park regime. Years are on the $x$-axis. Estimates for the effect of direct backward (Linkage $X$ Year) linkages are on y-axis. Full sample regressions control for the main $\mathrm{HCI} x$ Year effect. All regressions include controls for direct forward linkage connections, interacted with time. 95 percent confidence intervals are shown in gray. 
Figure G2: Relationship Between Total Backward Linkages on Upstream Output
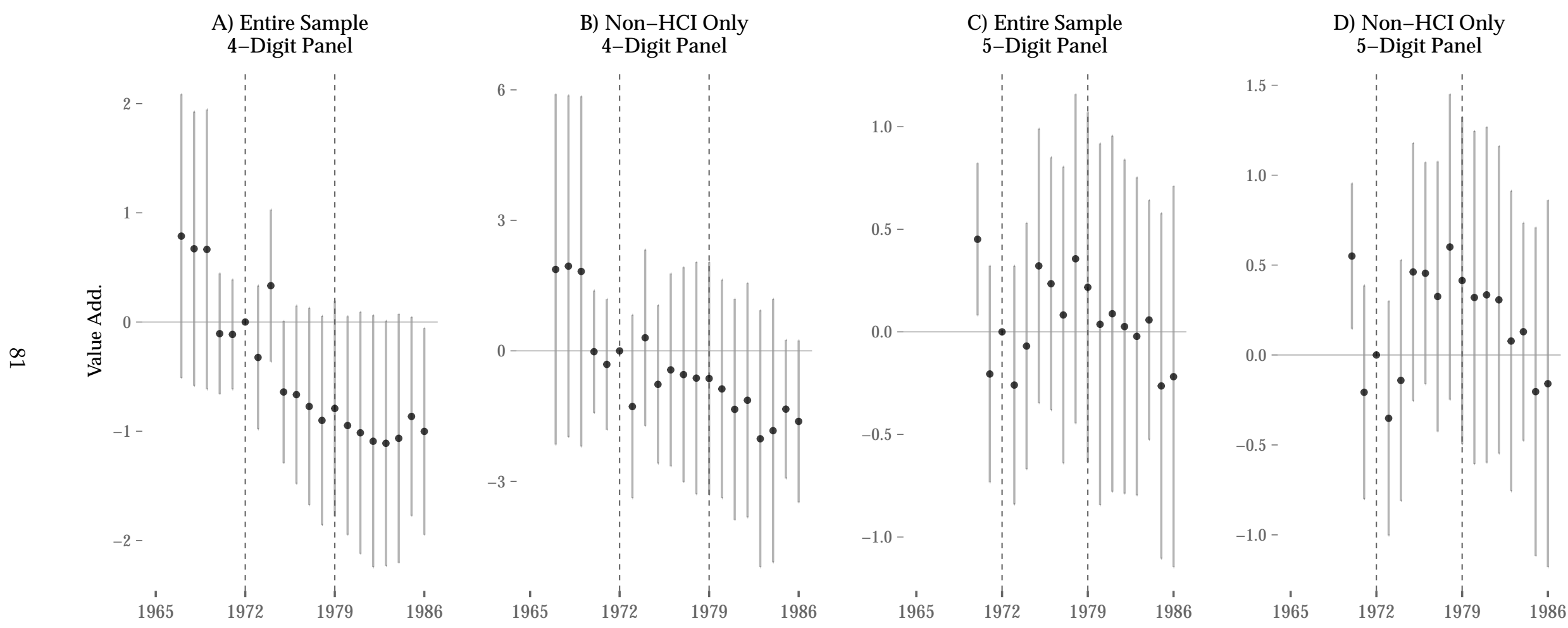

Notes: Figure plots dynamic differences-in-differences estimates for the relationship between total backward linkage exposure to HCI and outcomes: real value added. Estimates are relative to, 1972, the year before HCI. The year 1979 corresponds to collapse of Park regime. Years are on the x-axis. Estimates for the effect of total backward (Linkage X Year) linkages are on y-axis. Full sample regressions control for the main HCI x Year effect. All regressions include controls for total forward linkage connections, interacted with time. 95 percent confidence intervals are shown in gray. 
Figure G3: Impact of Backward Linkages (Direct v. Total) on Imported Goods

A) Backward Direct Linkages

Entire Sample

0.2

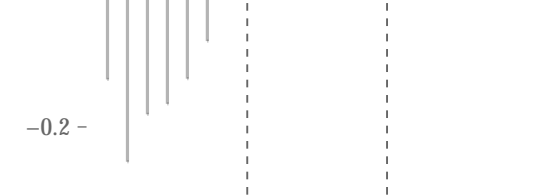

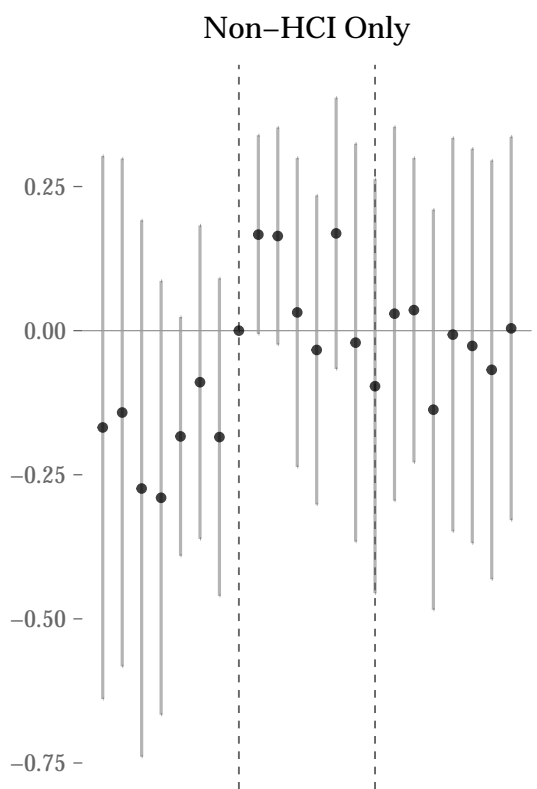

B) Backward Leontief Linkages
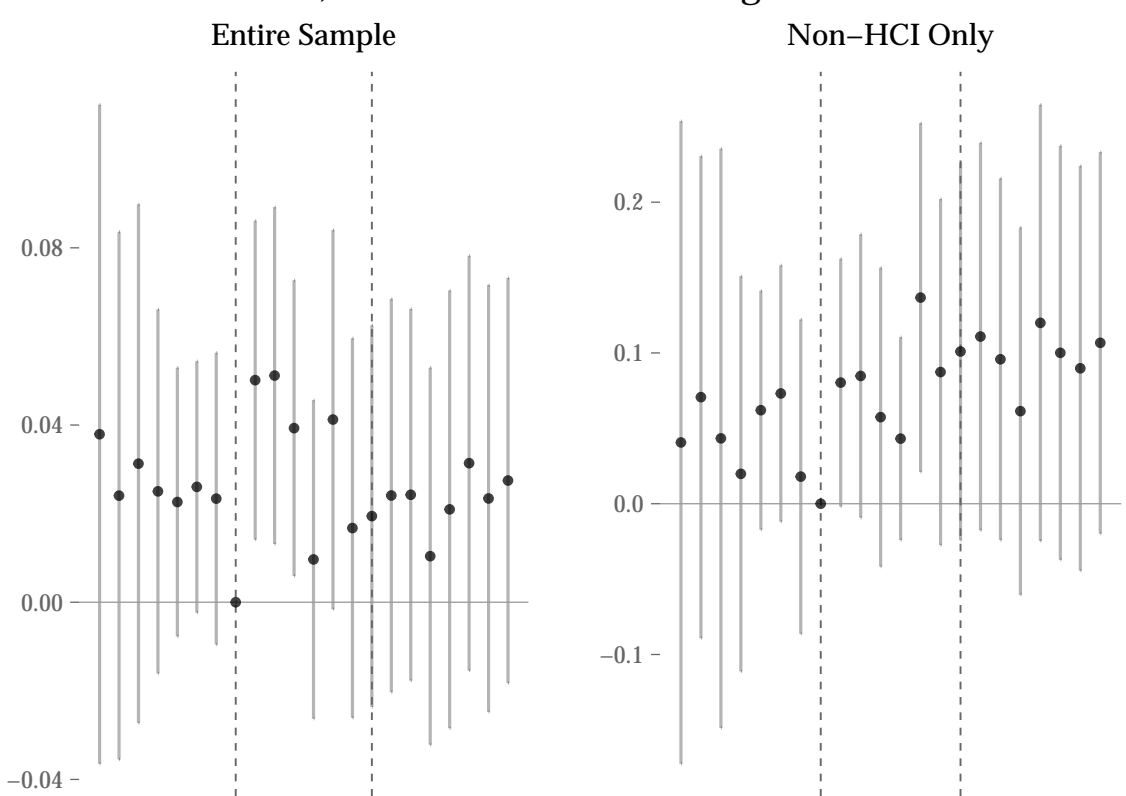

Notes: Figure plots dynamic differences-in-differences estimates for the relationship between (direct or total) backward linkage exposure to HCI and outcomes: real value of imports (ihs) Estimates are relative to, 1972, the year before HCI. The year 1979 corresponds to collapse of Park regime. Years are on the $\mathrm{X}$-axis. Estimates for the effect of (direct or total) backward (Linkage X Year) linkages are on y-axis. Full sample regressions control for the main HCI x Year effect. All regressions include controls for (direct or total) forward linkage connections, interacted with time. 95 percent confidence intervals are shown in gray. 
Figure H1: The Impact of HCI on Development, Restricting to Control Industries with Low HCI Linkages

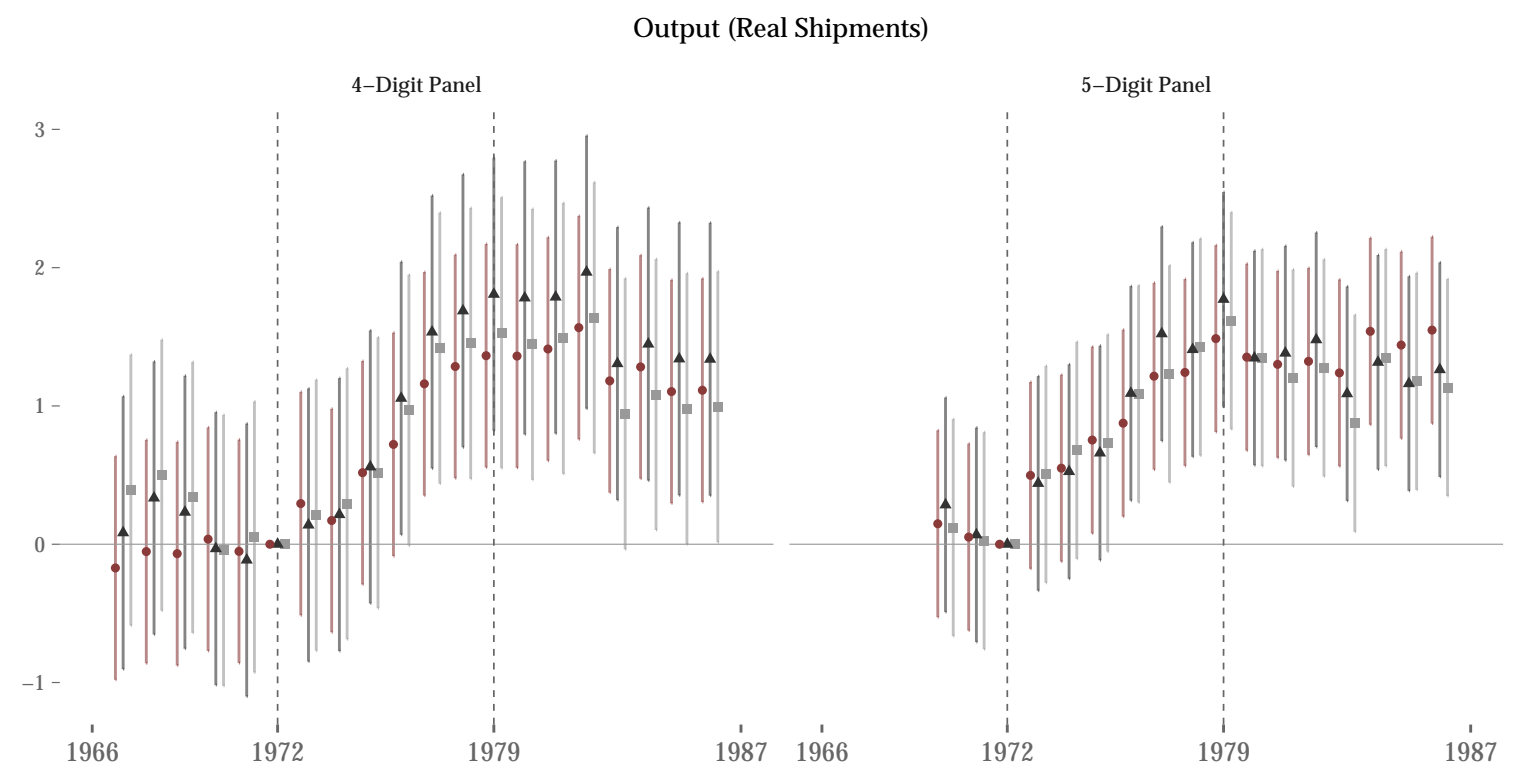

Labor Productivity

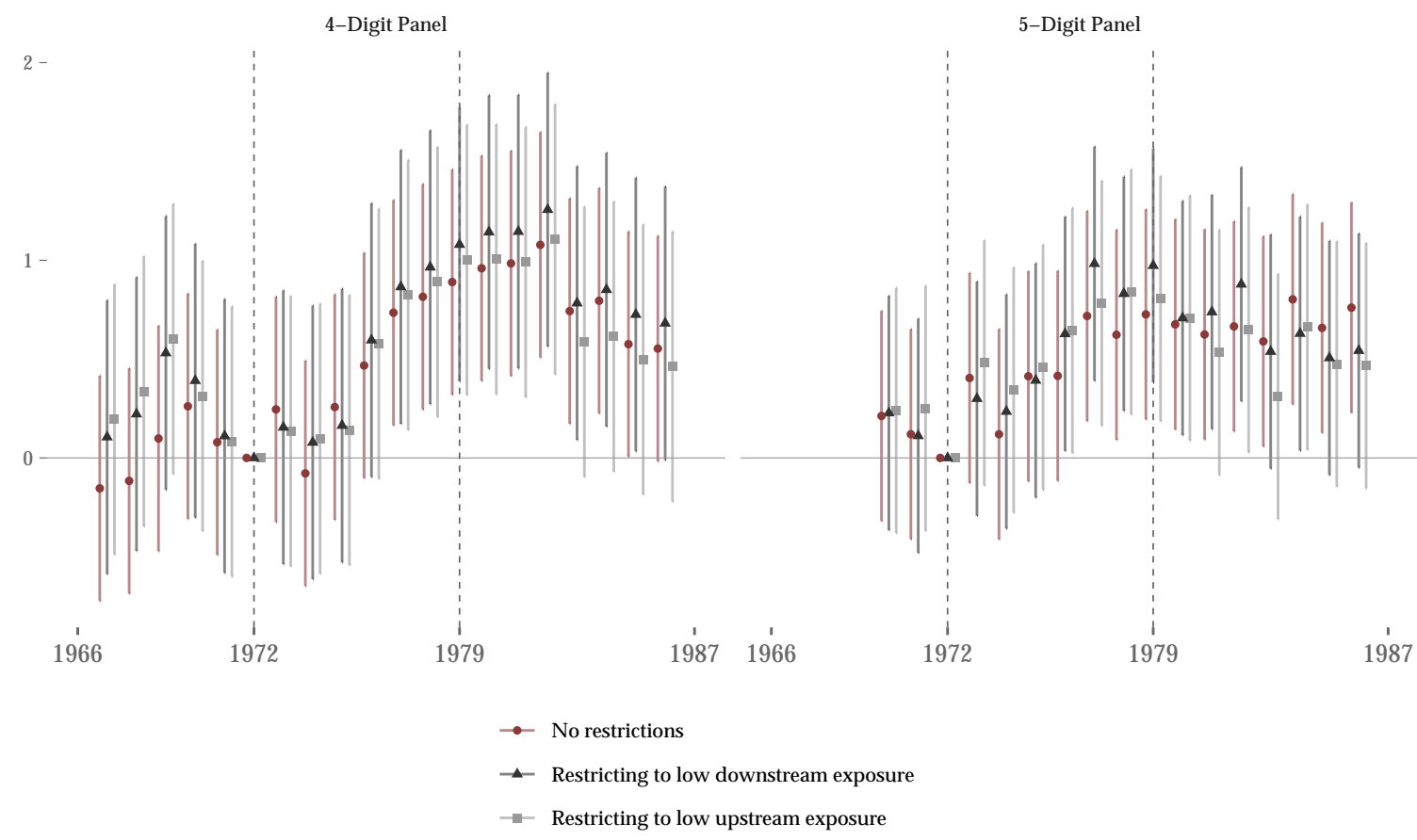

Note: Figure shows dynamic differences-in-differences estimates for the relationship between HCI and responses to industrial development outcomes. Estimates with and without controlling for linkage effects. Figure plots coefficients of interest from intereaction of interest: HCI x Year. Estimates are relative to 1972, the year before the HCI policy intervention. The line at 1972 is the start of the policy. The line at 1979 demarcates the fall of the Park regime. Standard errors are clustered at the industry-level and corrected for heteroskedasticity. Confidence bands are in light grey and correspond to 95 percent confidence intervals. 
Figure H2: The Impact of HCI on Development, Controlling for Non-Treated Linkages

Panels A - Direct Forward Linkages

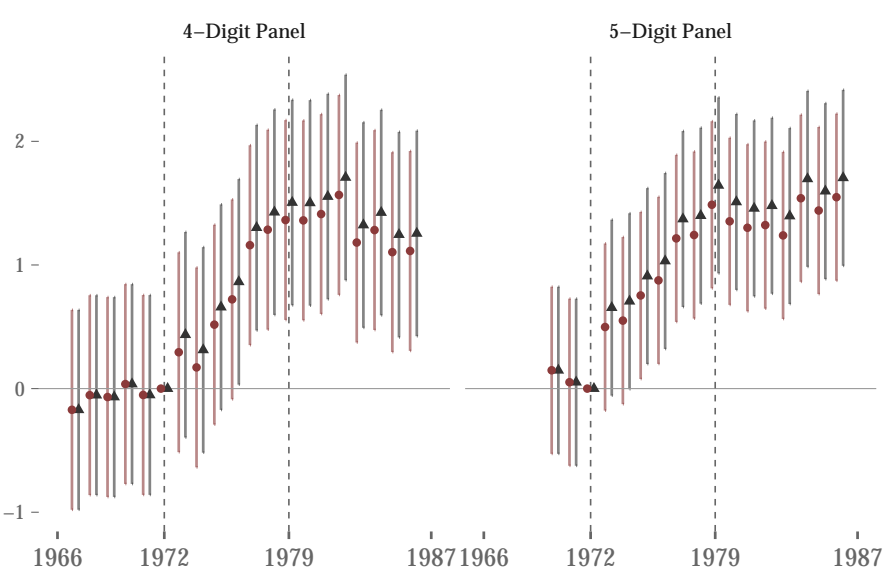

Panels B - Direct Forward and Backward Linkages

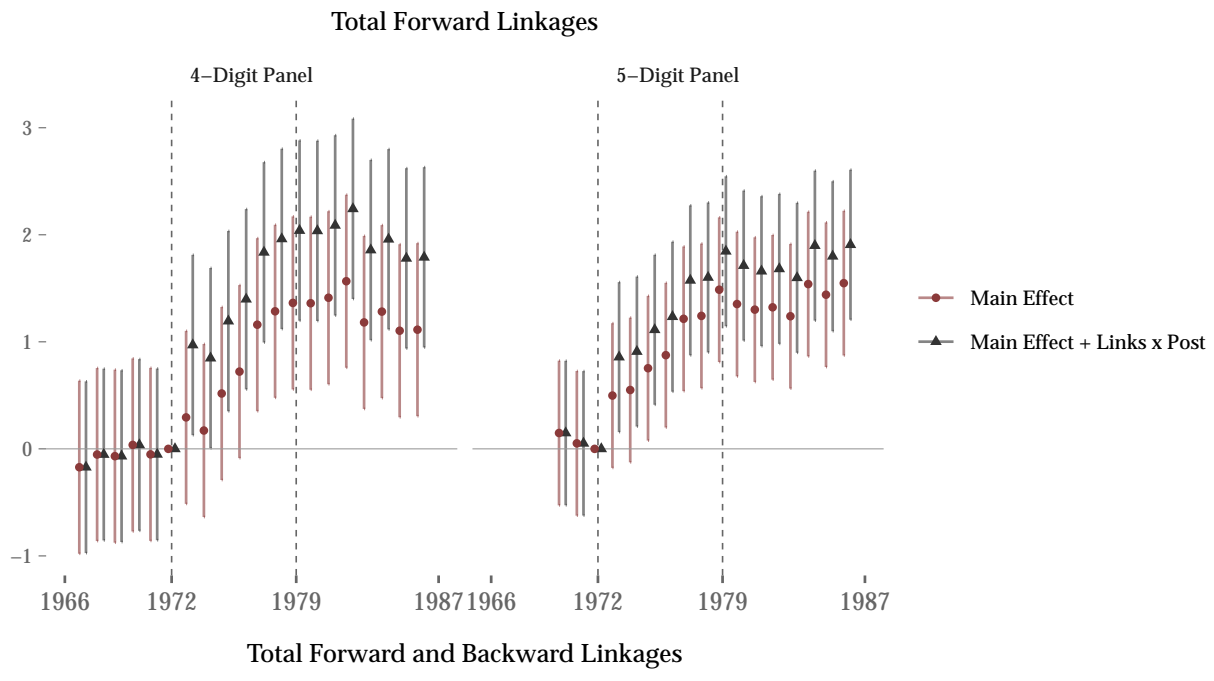

4-Digit Panel

5-Digit Panel

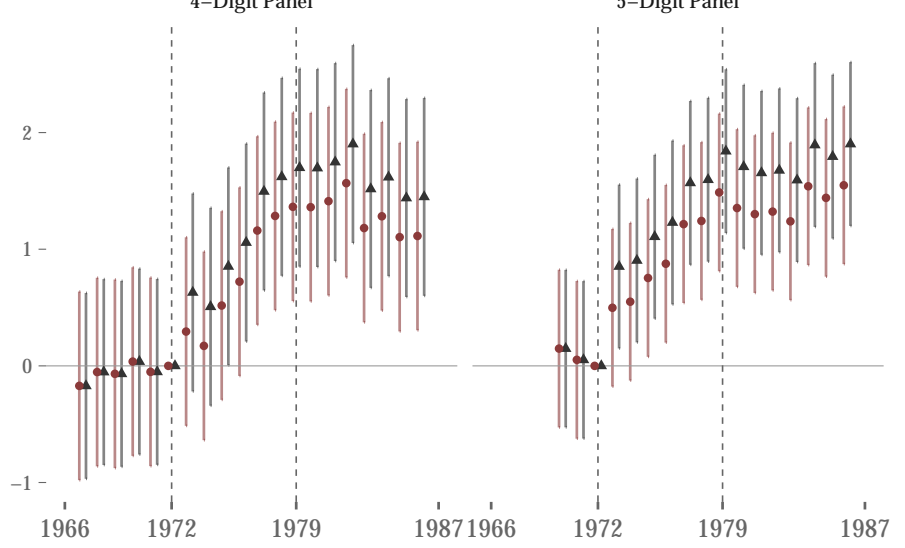

- Main Effect

$\_$Main Effect + Links x Post

Note: Figure shows dynamic differences-in-differences estimates for the relationship between $\mathrm{HCI}$ and responses to industrial development outcomes. Estimates with and without controls for linkage effects in non-treated sectors (linkage effects only for non-treated industry). Panels A compares baseline estimates to those controlling only for forward linkage effects, or downstream spillovers. Panel B compares baseline estimates to those controlling for both linkage effects. Figure plots coefficients of interest from intereaction of interest: HCI x Year. Estimates are relative to 1972, the year before the HCI policy intervention. The line at 1972 is the start of the policy. The line at 1979 demarcates the fall of the Park regime. Standard errors are clustered at the industry-level and corrected for heteroskedasticity. Confidence bands are in light grey and correspond to 95 percent confidence intervals. 
Figure H3: Relationship Between Investment and Capital Intensity, HCI and Non-HCI Industry.

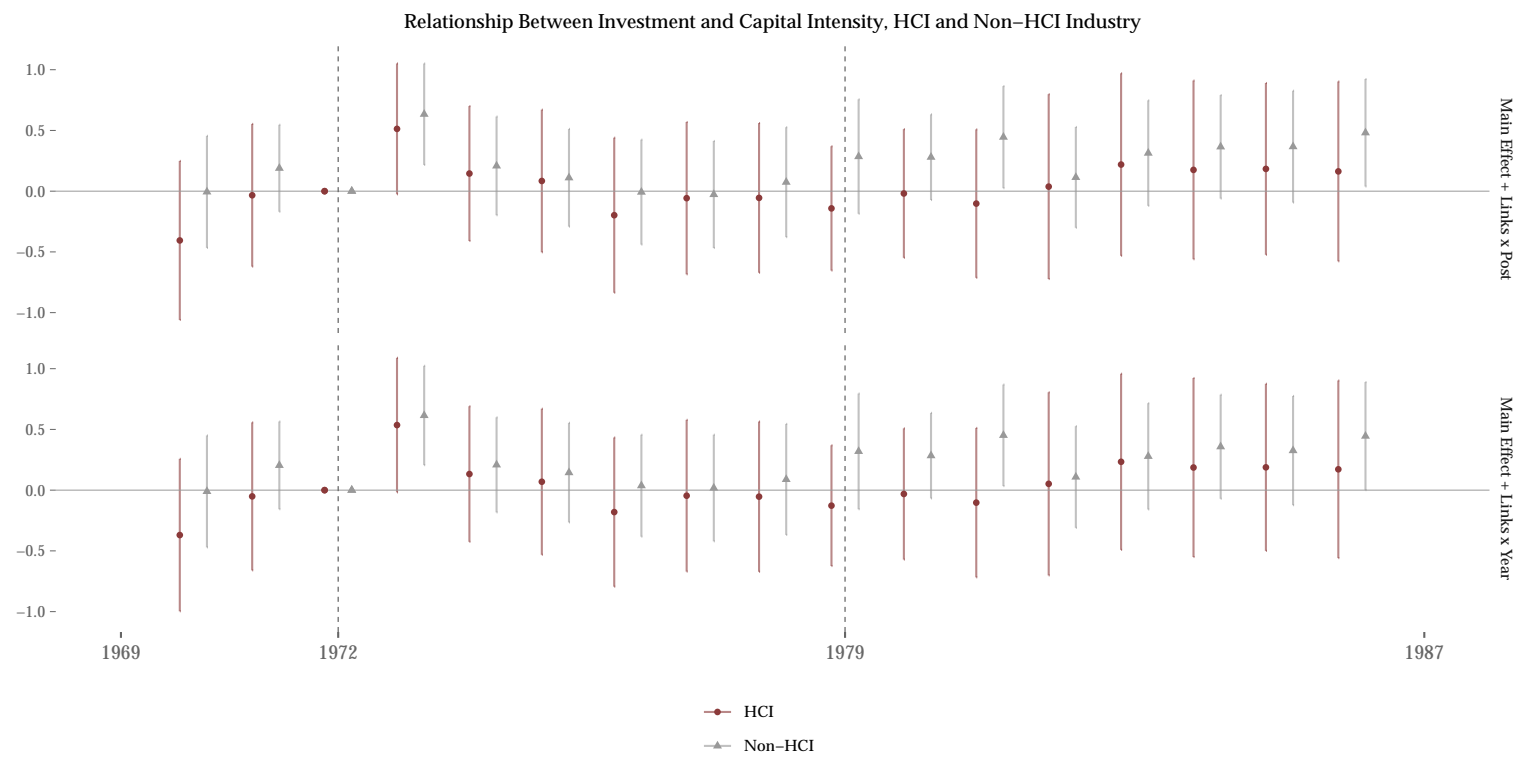

Note: Figure shows dynamic differences-in-differences estimates for the relationship between $\mathrm{HCI}$ and responses to investment incentives. Panels show the changes in investment (asinh) for $\mathrm{HCI}$ and non-HCI industry, relative to 1972, controlling for IO linkages as well. Regressions are performed on either the HCI-only or non-HCI samples. Coefficients are from the interaction Year x Capital Intensity, with 1972 as the omitted category. Pre-treatment capital intensity is measured as the pre-1973 levels of capital stock, divided by numbers of workers (asinh). Left panel plots the Year x Capital Intensity (main effects) with forward and backardlinkages interacted with a post-1973 indicator. Right panel plots the Year x Capital Intensity (main effects) with forward and backardlinkages interacted with a year indicator. Figure plots coefficients of interest from intereaction of interest: $\mathrm{HCI} x$ Year. Estimates are relative to 1972, the year before the HCI policy intervention. The line at 1972 is the start of the policy. The line at 1979 demarcates the fall of the Park regime. Standard errors are clustered at the industry-level and corrected for heteroskedasticity. Confidence bands are in light grey and correspond to 95 percent confidence intervals. 